\title{
METHODS FOR QUALITY-ASSURANCE REVIEW OF WATER-QUALITY DATA IN NEW JERSEY
}

Open-File Report 02-383

Prepared in cooperation with the NEW JERSEY DEPARTMENT OF ENVIRONMENTAL PROTECTION

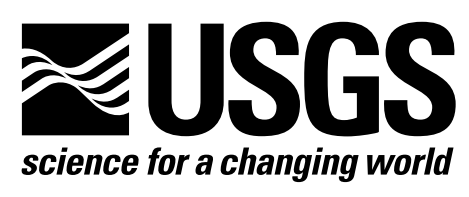




\section{METHODS FOR QUALITY-ASSURANCE REVIEW OF WATER-QUALITY DATA IN NEW JERSEY}

By G. Allan Brown, Edward A. Pustay, and Jacob Gibs

U.S GEOLOGICAL SURVEY

Open-File Report 02-383

Prepared in cooperation with the NEW JERSEY DEPARTMENT OF ENVIRONMENTAL PROTECTION

West Trenton, New Jersey 2003

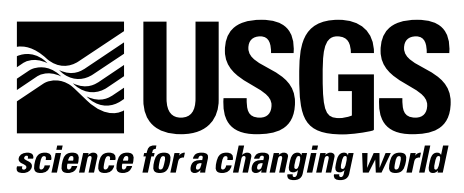




\section{U.S DEPARTMENT OF THE INTERIOR \\ GALE A. NORTON, Secretary}

\section{U.S. GEOLOGICAL SURVEY \\ Charles G. Groat, Director}

For additional information write to:

District Chief

U.S, Geological Survey

Mountain View Office Park

810 Bear Tavern Road, Suite 206

West Trenton, NJ 08628
Copies of this report can be purchased from:

U.S. Geological Survey

Branch of Information Services

Box 25286

Denver, CO 80225-0286 


\section{CONTENTS}

Page
Abstract
Introduction $A$
Purpose and scope
Output of COMP.PPL program

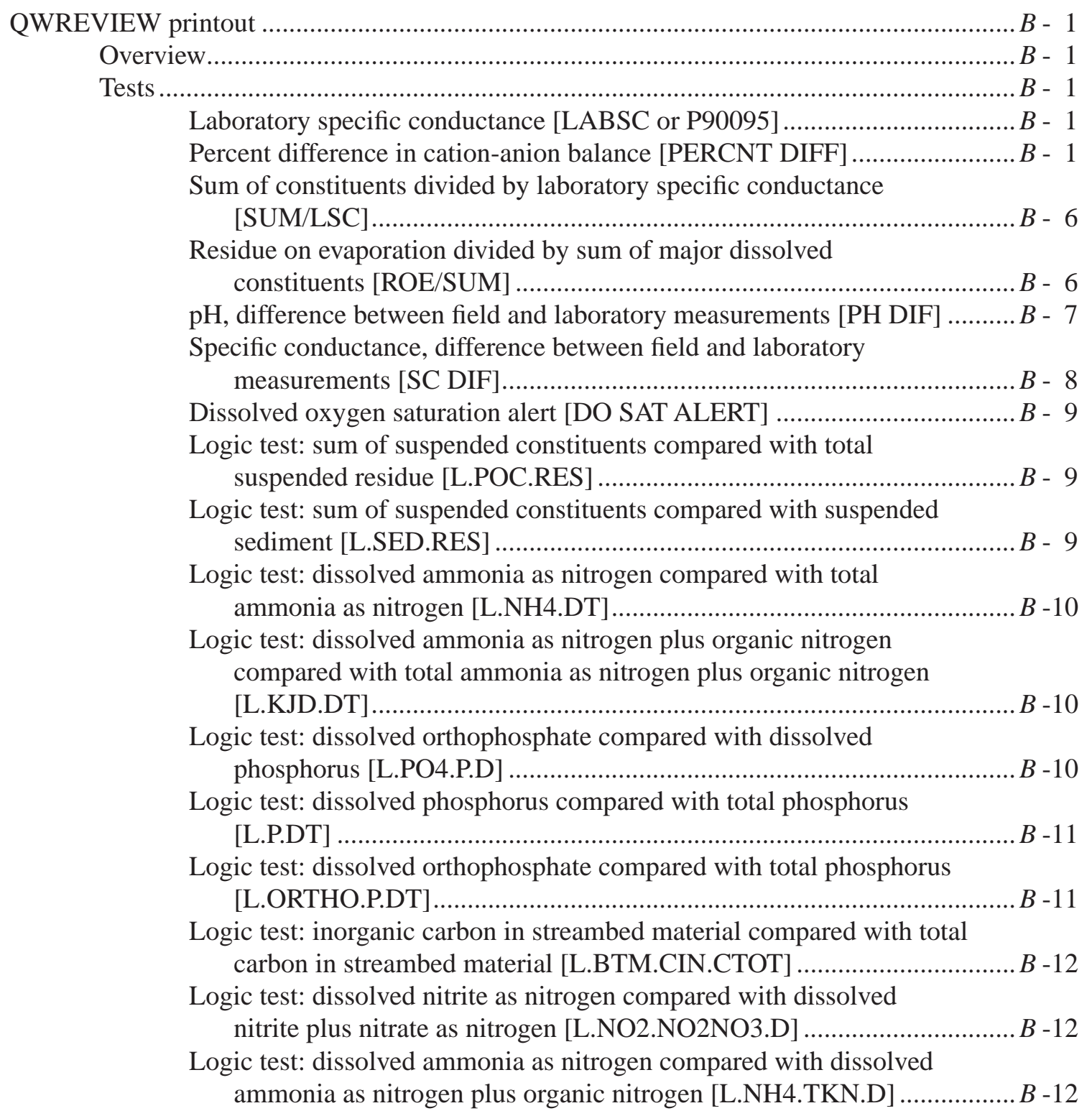




\section{CONTENTS--CONTINUED}

Page

Section B--Continued

Logic test: total ammonia as nitrogen compared with total ammonia as nitrogen plus organic nitrogen [L.NH4.TKN.T] ........................... $B-12$

Logic test: dissolved ammonia as nitrogen compared with total ammonia as nitrogen plus organic nitrogen [L.NH4.TKN.DT] .............. $B-13$

Sodium - potassium warning [NA.K.WARNING] .................................... $B-13$

Dissolved nitrite as nitrogen and percent saturation dissolved oxygen

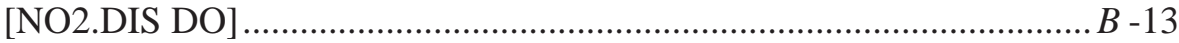

Dissolved nitrite plus nitrate as nitrogen, and dissolved oxygen

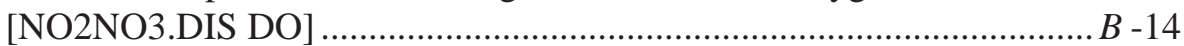

Magnesium to calcium ratio warning [CA MG RATIO WARN] .................. $B-14$

New Jersey drinking-water standards [Alert tests which begin with A followed by a constituent name] ............................................... B -15

Field alkalinity compared with laboratory ANC, surface-water samples

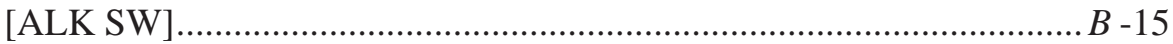

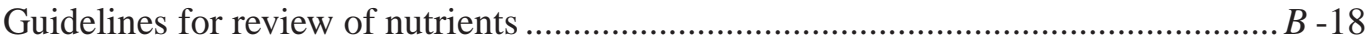

QWOUTLIERS printout

Section $C$

Outliers in general

$C-1$

Explanation of headings ........................................................................ 1

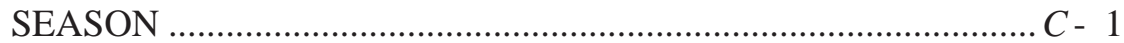

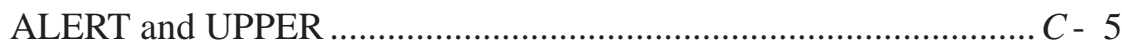

MIN, MAX and P values........................................................ 5

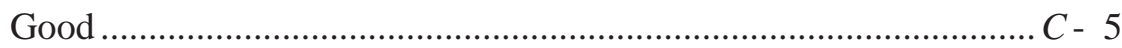

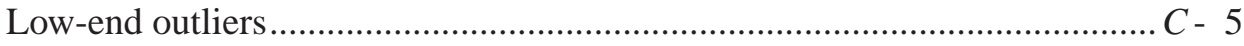

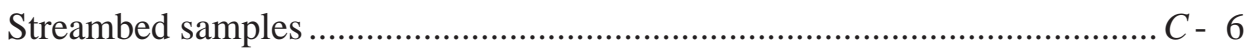

Old values in the statistical library ……….............................................. $C$ - 7

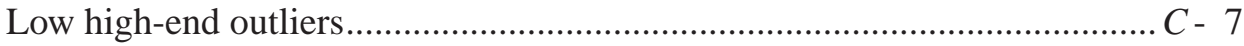

Section $D$

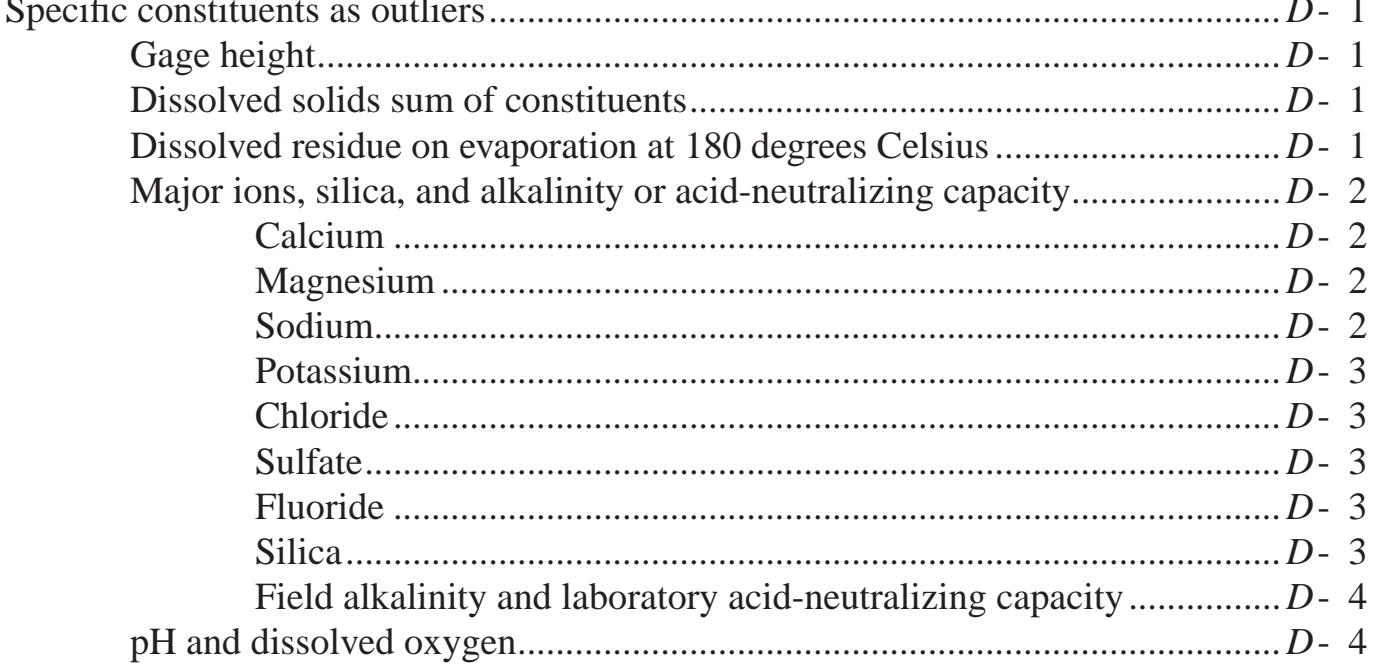




\section{CONTENTS--CONTINUED}

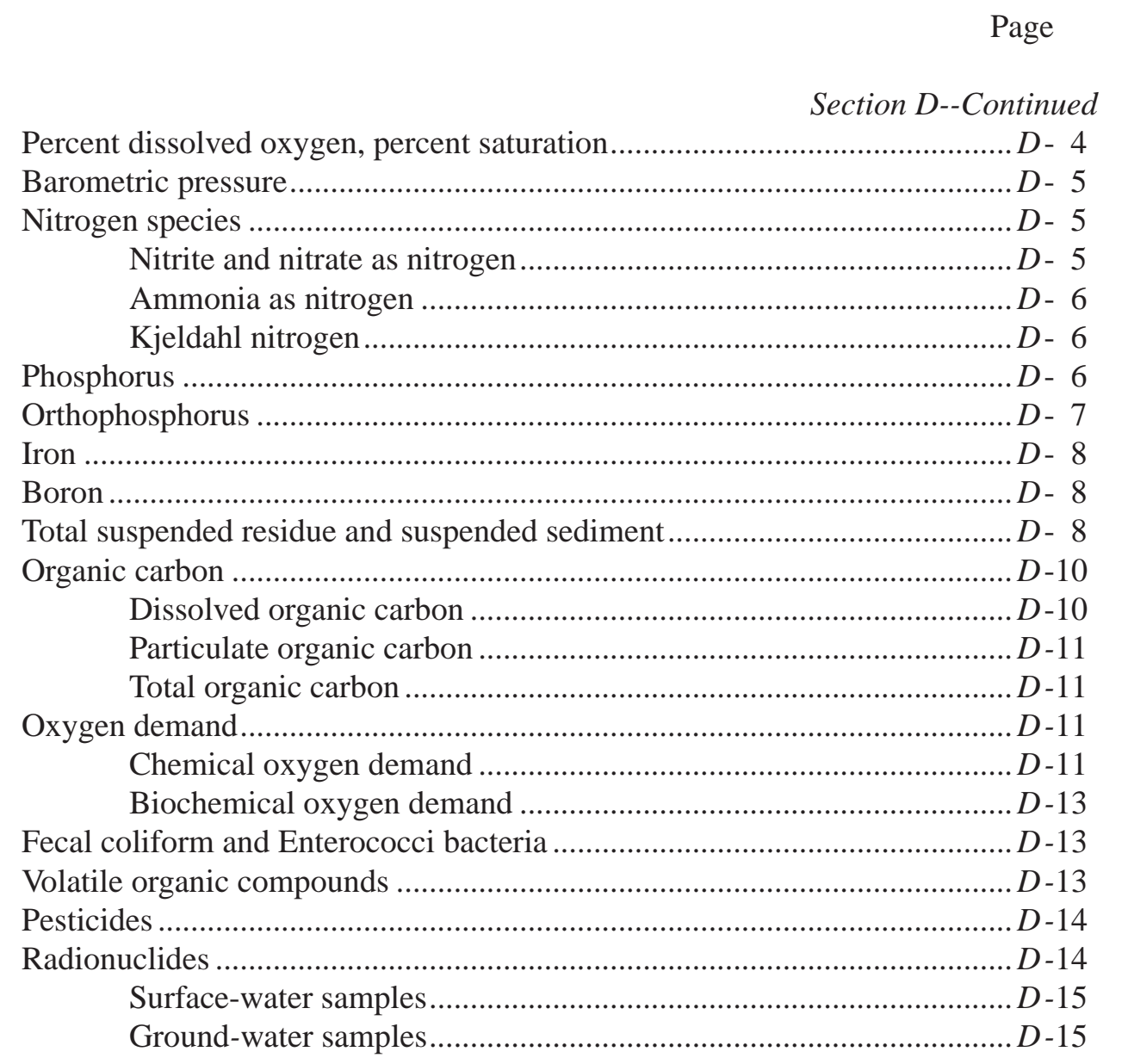

Section E

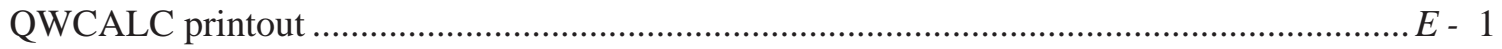

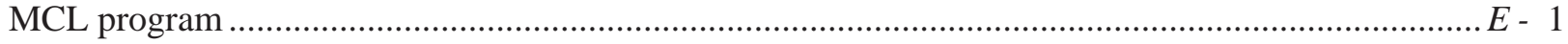

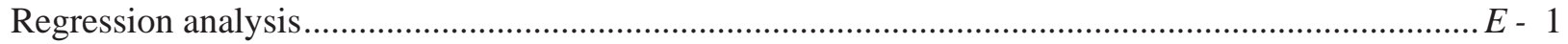

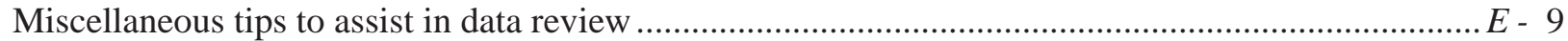

National Water Quality Laboratory Technical Memoranda................................................ E - 9

Reruns and verifications from the National Water Quality Laboratory .................................. $E$ - 9

National Water Quality Laboratory internal quality assurance ........................................... E -10

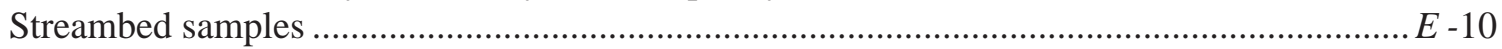

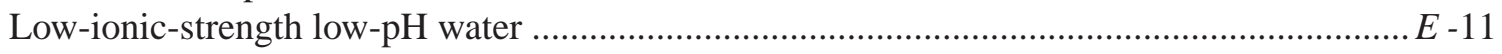

Section F

Summary

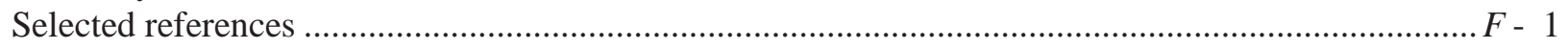




\section{ILLUSTRATIONS}

Figure 1. Flow chart showing the water-quality-data collection and review process in

New Jersey District ...

A- 2

2. Graph showing regression plot of suspended sediment concentration in relation to field turbidity for the Delaware River at Trenton, N.J.................................................... D - 9

3. Graph showing regression plot of UV 254 (ultraviolet-absorbing organic constituents, 254 nanometer wavelength) in relation to dissolved organic carbon for the Passaic River at Two Bridges, N.J .....

D-12

4. Graph showing regression plot of dissolved solids sum in relation to dissolved calcium

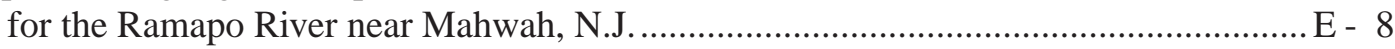

\section{TABLES}

Table 1. Example of output of QWREVIEW part of COMP.PPL computer program ....................... -2

2. Cation and anion percent difference acceptability .......................................................... $\mathrm{B}-5$

3. Tests for comparison of constituent concentrations with New Jersey drinking-

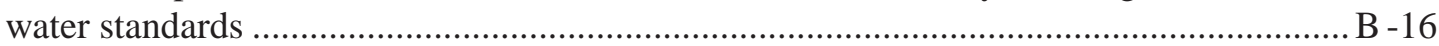

4. Example of output of QWOUTLIERS part of COMP.PPL computer program .................... - 2

5. Example of output of QWCALC part of COMP.PPL computer program ............................. E - 2

6. Description of parameter codes on the QWCALC printout ................................................. E - 4

7. Example of output of MCL computer program ................................................................... 5 


\section{CONVERSION FACTORS AND ABBREVIATIONS}

\begin{tabular}{|c|c|c|}
\hline Multiply & $\underline{\mathrm{By}}$ & $\underline{\text { To obtain }}$ \\
\hline \multicolumn{3}{|c|}{ Length } \\
\hline inch (in.) & 25.4 & millimeter $(\mathrm{mm})$ \\
\hline foot $(\mathrm{ft})$ & 0.3048 & meter $(\mathrm{m})$ \\
\hline mile (mi) & 1.609 & kilometer $(\mathrm{km})$ \\
\hline \multicolumn{3}{|c|}{ Volume } \\
\hline gallon (gal) & 3.785 & liter $(\mathrm{L})$ \\
\hline \multicolumn{3}{|c|}{ Flow } \\
\hline feet per second (ft/s) & 0.3048 & meter per second \\
\hline \multicolumn{3}{|c|}{$\underline{\text { Mass }}$} \\
\hline ounce, avoirdupois (oz) & $28 . \overline{35}$ & $\operatorname{gram}(\mathrm{gm})$ \\
\hline ounce, avoirdupois (oz) & 0.02835 & milligram (mg) \\
\hline \multicolumn{3}{|c|}{$\begin{array}{r}\text { Temperature } \\
{ }^{\circ} \mathrm{C}=5 / 9 \times(\mathrm{F}-3\end{array}$} \\
\hline
\end{tabular}

\section{Water-quality abbreviations}

$\begin{array}{ll}\mathrm{L} & \text { - liter } \\ \mathrm{meq} / \mathrm{L} & \text { - milliequivalents per liter } \\ \mathrm{mg} / \mathrm{g} & \text { - milligrams per gram } \\ \mathrm{mg} / \mathrm{kg} & \text { - milligrams per kilogram } \\ \mathrm{mg} / \mathrm{L} & \text { - milligrams per liter } \\ \mathrm{mm} \mathrm{Hg} & \text { - atmospheric pressure in millimeters of mercury } \\ \mathrm{pCi} / \mathrm{L} & \text { - picocuries per liter } \\ \mu \mathrm{g} / \mathrm{g} & \text { - micrograms per gram } \\ \mu \mathrm{g} / \mathrm{L} & \text { - micrograms per liter } \\ \mu \mathrm{S} / \mathrm{cm} & \text { - microsiemens per centimeter at } 25 \text { degrees Celsius } \\ \mathrm{AGWQN} & \text { - Ambient-Ground-Water-Quality Network } \\ \mathrm{ANC} & \text { - acid-neutralizing capacity } \\ \mathrm{ASMN} & \text { - Ambient-Stream-Monitoring Network } \\ \mathrm{ASR} & \text { - analytical services request form } \\ \mathrm{BOD} & \text { - biological oxygen demand } \\ \mathrm{COD} & \text { - chemical oxygen demand } \\ \text { DO } & \text { - dissolved oxygen } \\ \text { DOC } & \text { - dissolved organic carbon } \\ \text { DOSAT } & \text { - dissolved oxygen saturation in percent } \\ \text { DQI } & \text { - data-quality indicator }\end{array}$




\title{
CONVERSION FACTORS AND ABBREVIATIONS-- CONTINUED
}

\author{
Water-quality abbreviations--Continued \\ KJD - Kjeldahl (nitrogen) \\ LRL - laboratory reporting level \\ MCL - maximum contaminant level \\ MRL - minimum reporting level \\ NJDEP - New Jersey Department of Environmental Protection \\ NJDOH - New Jersey Department of Health and Senior Services \\ NTU - nephelometric turbidity unit \\ NWIS - National Water Information System \\ NWQL - National Water Quality Laboratory, Denver, Co. \\ $\mathrm{PC} \quad$ - parameter code \\ POC - particulate organic carbon \\ Q $\quad$-stream discharge \\ ROE - Residue on evaporation at 180 degrees Celsius \\ SC - specific conductance \\ SUM - Dissolved solids sum of constituents \\ T -temperature \\ TDS - total dissolved solids \\ TOC - total organic carbon \\ USEPA - U.S. Environmental Protection Agency \\ VOC - volatile organic compound
}




\title{
METHODS FOR QUALITY-ASSURANCE REVIEW OF WATER-QUALITY DATA IN NEW JERSEY
}

\author{
By G. Allan Brown, Edward A. Pustay, and Jacob Gibs
}

ABSTRACT

This report is an instructional and reference manual that describes methods developed and used by the U.S. Geological Survey (USGS), New Jersey District, to assure the accuracy and precision of the results of analyses of surface- and ground-water samples received from analyzing laboratories and, ultimately, to ensure the integrity of water-quality data in USGS databases and published reports. A statistical-analysis computer program, COMP.PPL, is used to determine whether the values reported by the laboratories are internally consistent, whether they are reasonable when compared with values for samples previously collected at the same site, and whether they exceed applicable drinking-water regulations. The program output consists of three files -QWREVIEW, QWOUTLIERS, and QWCALC. QWREVIEW presents the results of tests of chemical logic and shows values that exceed drinking-water regulations. QWOUTLIERS identifies values that fall outside the historical range of values for the site sampled. QWCALC shows values and calculations used for reference purposes.

Because values that are identified by the program as questionable may or may not be in error, the reviewer looks at both qualitative and quantitative relations between analytes during the period of record and then uses technical judgement to decide whether to accept a questionable value or investigate further. Guidelines for, and the use of regression analysis in, making this decision are described. Instructions are given for requesting that the analyzing laboratory reanalyze a constituent or otherwise verify the reported value. If, upon reanalysis or verification, a value is still questionable, consideration must be given to deleting the value or marking the value in the USGS National Water Information System database as having been reviewed and rejected.
INTRODUCTION

Many steps are involved in the collection, review, and publication of water-quality data in the New Jersey District. To assure that the data are accurate, a series of steps are followed by New Jersey District personnel. These steps are illustrated in the flow chart in figure 1. The section of the chart labeled Quality Assurance of Data is the subject of this report.

Samples of surface water and ground water collected by the New Jersey District are analyzed primarily by the U.S. Geological Survey's National Water Quality Laboratory (NWQL). The laboratories of the New Jersey Department of Health and Senior Services (NJDOH) also are used for the analysis of some constituents, including bacteria, ammonia, and nitrite. Results of analyses from NWQL are received in a tabular format called a WATLIST table. This WATLIST table is an output file containing a listing of records transmitted by NWQL, a cation-anion balance table, and a list of any error messages (U.S. Geological Survey, 2001, section 2.1.8).

Results of analyses of surface- and groundwater samples reported by laboratories are evaluated for precision and accuracy in order to ensure the integrity of water-quality data in U.S. Geological Survey (USGS) databases and published reports. In order to accomplish this task in a scientific, uniform, and systematic way, the USGS, in cooperation with the New Jersey Department of Environmental Protection (NJDEP), developed a computer program to test the results of the chemical analysis of a water sample to determine whether the chemistry is internally consistent, whether any values are outside the historical range of values for that sampling site, and whether any constituent values exceed the drinking-water standards established by the NJDEP (Shelton, 1996) or the U.S. 


\section{PREPARATION FOR DATA COLLECTION}

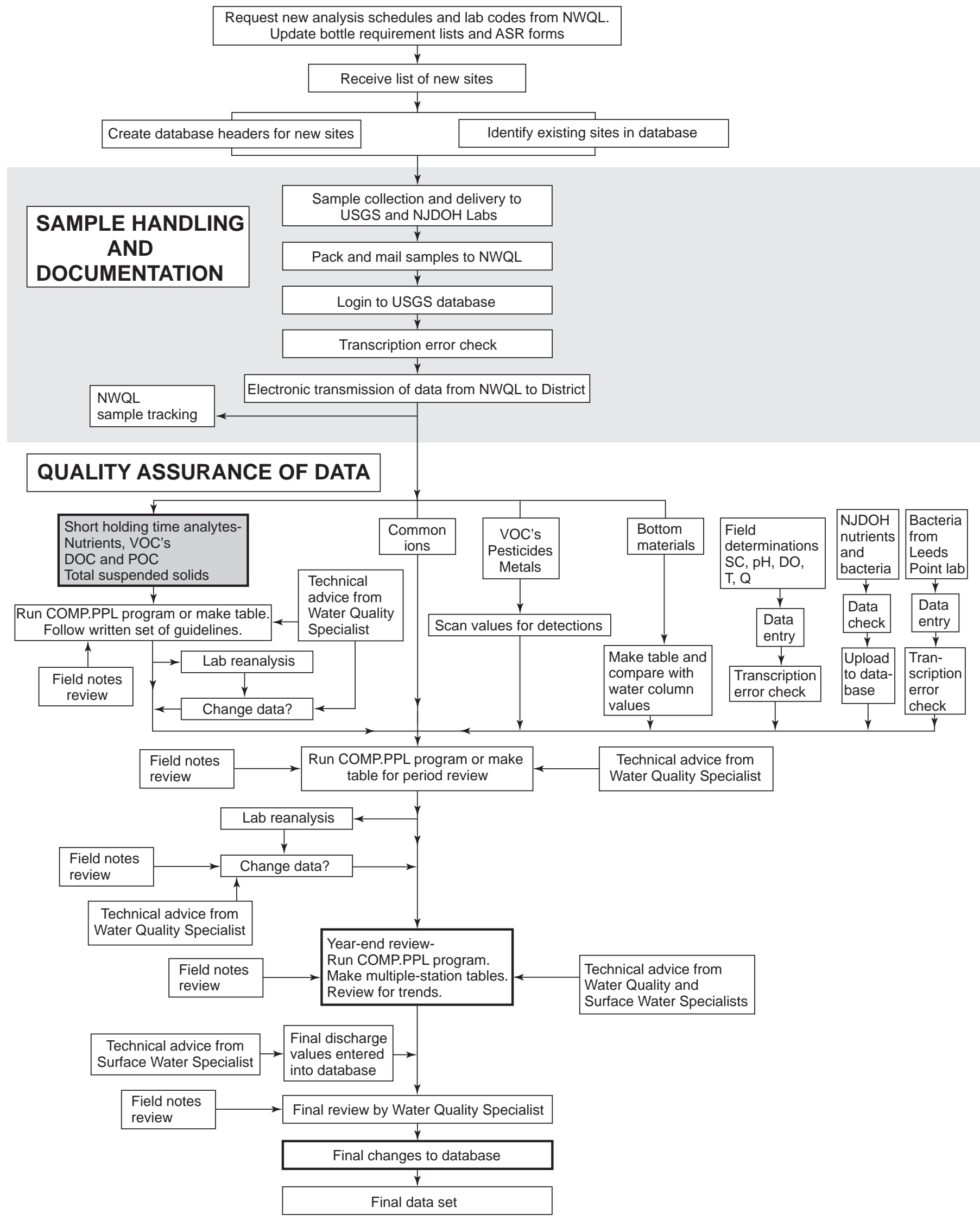

Figure 1. Water-quality-data collection and review process in New Jersey District. (Shaded box indicates types of data that must be reviewed on receipt from NWQL so that any needed reanalyses can be requested before samples are discarded.) 
Environmental Protection Agency (USEPA) (U.S. Geological Survey, 2001, appendix E). The program also tests the validity of values of properties or constituents measured in the field, such as dissolved oxygen concentration, water temperature, and barometric pressure.

In practice, only a small fraction of the cases identified as questionable by the program COMP.PPL require reanalysis or verification by the laboratory. The reviewer must use technical judgement when deciding whether to investigate a questionable value. The USGS, in cooperation with the NJDEP, developed a series of guidelines that can be used to help ensure that the qualityassurance data-review process is applied uniformly by all personnel at all times.

Of the values requiring reanalysis or verification by laboratories, only a small number of those are found unacceptable after the laboratory's reply. In those cases, the value is deleted from the database or marked in the database with a data-quality indicator (DQI) of Q which means the value has been reviewed and rejected. The use of DQI equal to Q is usually preferable to deletion of a value.

\section{PURPOSE AND SCOPE}

This report is an instructional and reference manual for USGS personnel who conduct qualityassurance reviews of water-quality data. The methods used in the USGS, New Jersey District, to ensure that the results of analyses of surface-water and ground-water samples are internally consistent and are reasonable within the historical context for a particular sampling site are explained. The use of a statistical-analysis computer program is described. The interpretation of the program's three output files is described in detail, and criteria are presented to help the data reviewer determine whether to investigate questionable data values.
The use of regression analysis as a tool to evaluate the validity of questionable data values also is described.

Although examples in the report are specific to New Jersey, many suggestions are offered that are applicable to the review of the results of analyses of water samples collected at any location. Services offered by the USGS National Water Quality Laboratory and instructions for obtaining these services are included.

\section{ACKNOWLEDGMENTS}

Thanks are extended to the personnel of the Water-Quality Unit of the Hydrologic Data Assessment Program of the New Jersey District who have used a version of this document for several years and provided suggestions for improvement of the text.

\section{COMP.PPL COMPUTER PROGRAM}

The statistical analysis computer program COMP.PPL was written in P-STAT ${ }^{1}$ programming language (P-STAT, Inc., 1997) ${ }^{2}$ to assist project personnel in the review of water-quality data from both surface- and ground-water sites. COMP.PPL is used to determine whether measurements made in the field and laboratory analytical results for a sample are internally consistent and whether the results are reasonable when compared with those from samples previously collected at that site. The COMP.PPL program is run at least three times, as shown in the flow chart (fig.1) in order to help the reviewer ensure the quality of the data collected. Data reviewers initially use the reports created by the program to evaluate new data and make written comments on the file copy of the laboratory analysis that are based on the reports. If the

\footnotetext{
${ }^{1}$ Use of brand or company names in this report is for identification purposes only and does not constitute endorsement by the U.S. Geological Survey.

${ }^{2}$ As of the date of publication, the program is being rewritten in Microsoft Access by E. A. Pustay.
} 
evaluation shows sufficient cause, the reviewer requests that the laboratory reanalyze or verify questionable results, or in the case of field determinations, the reviewer verifies that the data in the database agree with values on the original field form. The program is also executed by personnel in the New Jersey District as data are being reviewed prior to publication in the District's annual data report series "Water Resources Data-New Jersey."

The program requires an input data set of values in P-STAT format retrieved from the National Water Information System (NWIS) (U.S. Geological Survey, 2001) database and a library of statistical values in P-STAT format that is prepared yearly after publication of the annual data report. Remark codes such as < or E are removed from the value if they are present.

\section{OUTPUT OF COMP.PPL} PROGRAM

The program output consists of printouts of three files, which will be described in detail in following sections. Each of these files is represented by a major heading in this report. Within each of these headings, the discussion is presented generally in the order in which the items appear in the program output. Criteria are presented to help the data reviewer determine whether a problem exists and, if so, how to proceed. A brief description of the three output files is given here.

QWREVIEW presents an evaluation of major ions and field determinations, performs logical comparisons between constituents, and compares values to drinking-water standards of the NJDEP (Shelton, 1996) and USEPA (U.S. Geological Survey, 2001, appendix E).
QWOUTLIERS identifies results that are questionable when compared with historical results for the same site.

QWCALC presents reference values of measurements and computations from the data set that the reviewer can use to judge questionable analytical results.

The QWREVIEW and QWOUTLIERS output files are constructed in such a way that only results that are questionable are printed. It is on these printed results that the reviewer will focus to determine whether there is a problem with the analysis. In many cases, if the QWREVIEW output indicates a problem, the reviewer uses the QWOUTLIER output, and possibly regression analysis, to isolate results that need to be reanalyzed or verified. 


\section{QWREVIEW PRINTOUT}

\section{Overview}

The QWREVIEW printout (table 1) is designed to draw attention to results that are questionable. It provides an evaluation of the ion balance and logical comparisons between selected constituents; it also alerts the reviewer to values greater than drinking-water standards of the NJDEP (Shelton, 1996) and USEPA (U.S. Geological Survey, 2001, appendix E). Chemical logic tests have heading captions that begin with the letter L and ask questions such as: Is a part greater than the whole? or Are two measurements that should be close in value too different from each other? Alert tests all have headings that begin with the letter A; if a value is printed here, it means the value is greater than NJDEP or USEPA drinking-water standards for that particular constituent. The results of alert tests are used only when the water sampled represents a source of drinking water. Information on each sample is shown on a single line that spans several pages and is identified by station number and date. Columns that follow the date list the results of tests when there is cause to question a result; three dashes are printed when tests are passed and a single dash is printed when a test cannot be performed because of missing data. When the printout indicates the need for evaluation of values, the reviewer can use the output from other programs described in this report to confirm or isolate problems.

The criteria used in the following tests often were chosen to evaluate specific aspects of New Jersey water samples. Where criteria are based primarily on long-term observations of constituent values for New Jersey water, this fact is mentioned in the comments for that test.

\section{Tests}

The tests that are performed are described below. Reporting units of analytes are milligrams per liter in the elemental form unless otherwise noted; specific conductance is in microsiemens per centimeter $(\mu \mathrm{S} / \mathrm{cm})$ at 25 degrees Celsius $\left({ }^{\circ} \mathrm{C}\right)$; and $\mathrm{pH}$ is in standard $\mathrm{pH}$ units. An example QWREVIEW report is shown in table 1.

\section{LABORATORY SPECIFIC CONDUCTANCE}

\section{Test name.-- LABSC or P90095}

Parameter code.-- Laboratory specific conductance, 90095

Comments.-- Laboratory specific conductance is printed for each sample as an initial point of reference. Values less than $100 \mu \mathrm{S} / \mathrm{cm}$ could reflect dilution from recent rainfall or normally low-ionic-strength water at a sampling location. Early recognition of either condition can help the reviewer evaluate the analytical report for that sample.

\section{Percent difference in CATION-ANION BALANCE}

\section{Test name.-- PERCNT DIFF}

Calculation.-- The cation concentration is calculated by summing the milliequivalents of dissolved calcium $(\mathrm{Ca})$, magnesium $(\mathrm{Mg})$, sodium $(\mathrm{Na})$, potassium $(\mathrm{K})$, iron $(\mathrm{Fe})$, manganese $(\mathrm{Mn})$, ammonia (NH4), and hydrogen $(\mathrm{H})$. Anion concentration is calculated by summing the milliequivalents of dissolved chloride $(\mathrm{Cl})$, sulfate (SO4), carbonate $(\mathrm{CO} 3)$, bicarbonate $(\mathrm{HCO} 3)$, fluoride (F), nitrite (NO2), nitrate (NO3), and orthophosphate (PO4). For samples with a PO4 concentration that is more than 5 percent of the anions, the alkalinity should be corrected for the amount of PO4 titrated. The percent difference is calculated by taking the difference between milliequivalents of cations and anions, dividing it by the sum of the two, then expressing it as a percentage.

All of the ions except hydrogen, iron, manganese, fluoride, and phosphate are mandatory to the calculation. The hydrogen ion concentration is calculated as the antilogarithm of $\mathrm{pH}$. The 


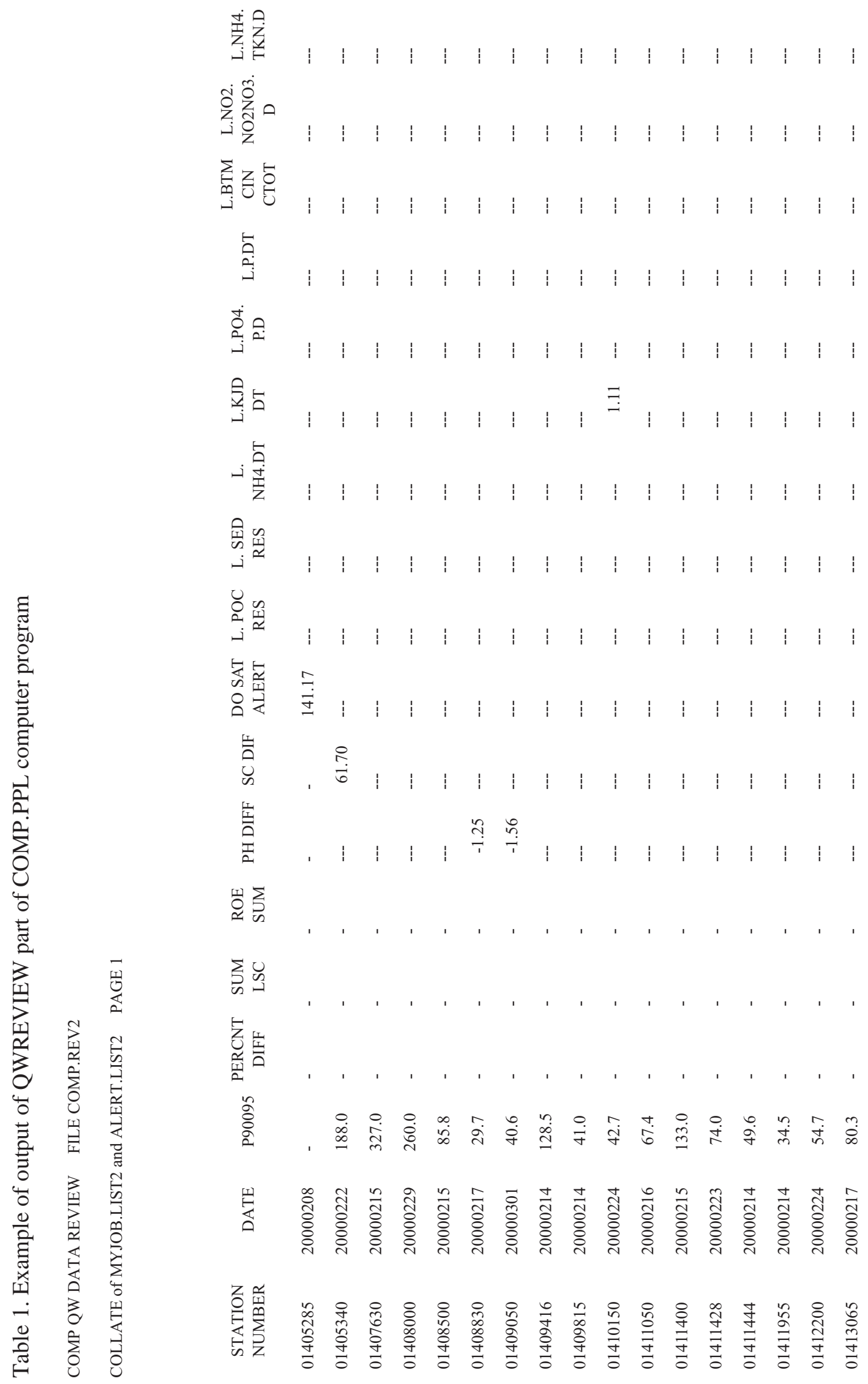




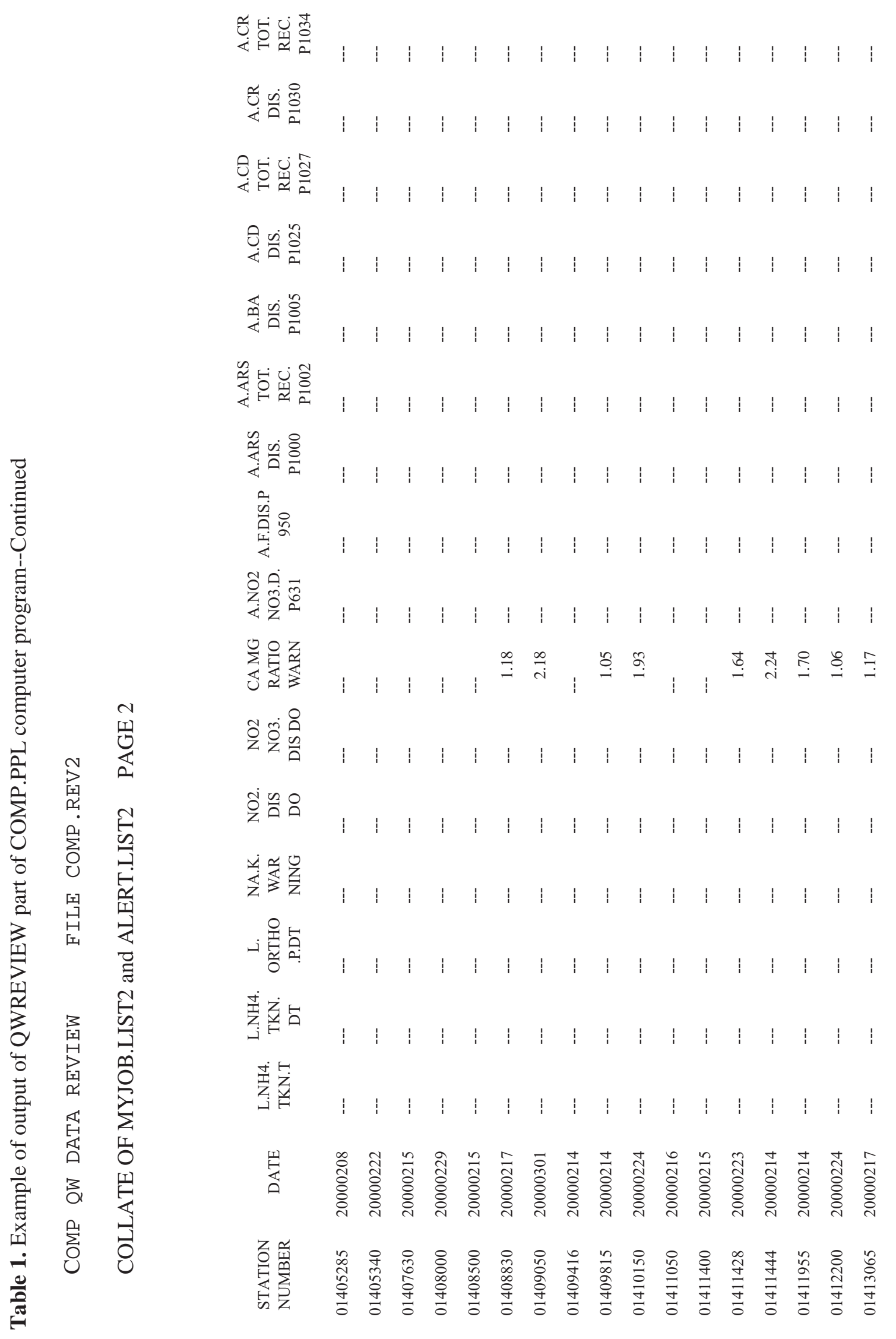




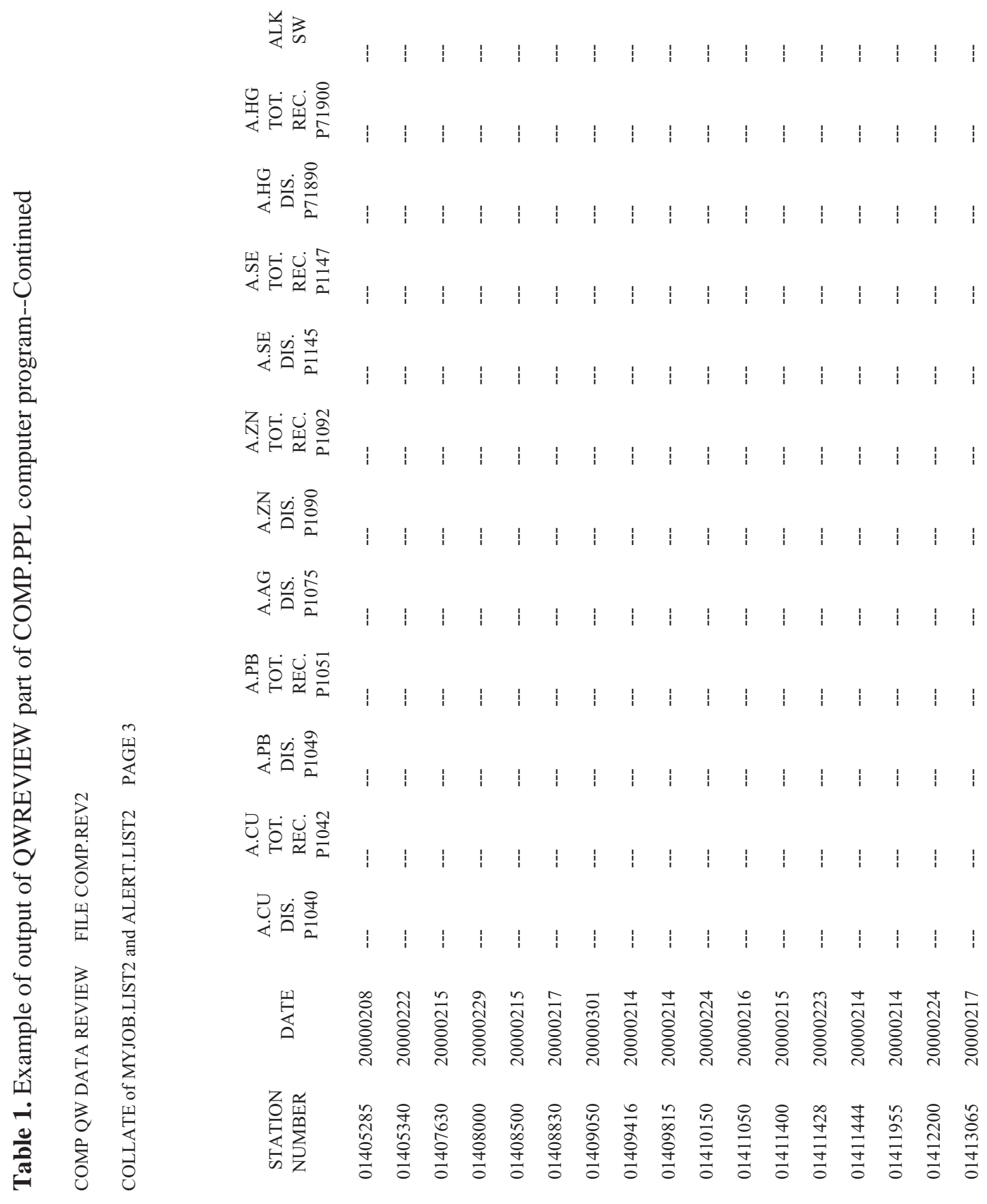


bicarbonate concentration is obtained from field titration of carbonate and bicarbonate, if available; if they are not available, field alkalinity or laboratory ANC (acid neutralizing capacity, previously called alkalinity) is used. For oxygenated water (dissolved oxygen concentration greater than $1.5 \mathrm{mg} / \mathrm{L}$ ), iron is considered to be trivalent in the ion balance calculation. This assumption produces better agreement for the ion balance calculation of cations and anions.

\section{Parameter codes}

Dissolved calcium, 00915

Dissolved magnesium, 00925

Dissolved sodium, 00930

Dissolved potassium, 00935

Dissolved fluoride, 00950

Dissolved silica, 00955

Dissolved iron, 01046

Dissolved manganese, 01056

Dissolved ammonia, 00608

$\mathrm{pH}$, standard $\mathrm{PH}$ units, 00400 (field) or 00403 (laboratory)

Dissolved chloride, 00940

Dissolved sulfate, 00945

Dissolved carbonate, 00452, and dissolved bicarbonate, 00453 (or field alkalinity, 39086, or laboratory ANC, 90410)

Dissolved nitrite, 00613

Dissolved nitrite plus nitrate, 00631

Dissolved phosphorus, 00666 (or phosphorus, orthophosphate, 00671)

Reported.-- The percent difference is reported when outside the range of acceptability, as determined by the ionic strengths used in the calculation (see table 2).
Table 2. Cation and anion percent difference acceptability $^{1}$

\begin{tabular}{ll}
$\begin{array}{l}\text { Ionic strength } \\
\text { (milliequivalents } \\
\text { per liter) }\end{array}$ & $\begin{array}{l}\text { Acceptable } \\
\text { range } \\
\text { (percent) }\end{array}$ \\
\hline $\begin{array}{l}0 \text { to } 0.2809 \\
0.281 \text { to } 0.5609\end{array}$ & -28 to +28 \\
0.561 to 0.8309 & -14.9 to +14.9 \\
0.831 to 1.109 & -10.2 to +10.2 \\
1.11 to 1.409 & -7.6 to +7.6 \\
1.41 to 1.709 & -6.0 to +6.0 \\
$>1.71$ & -5.5 to +5.5
\end{tabular}

${ }^{1}$ Modified from Friedman and Erdman, 1982, fig. 15.

Comments.-- Ion-balance percent differences can be quite different on the COMP.PPL printout and the NWIS printouts of laboratory and field data. The difference shown on the COMP.PPL printout is always the more accurate value for several reasons. One reason is that hydrogen ion $(\mathrm{H}+)$ is never included in the ion-balance percent difference on the NWIS printout, whereas it is included in the ion-balance percent difference in the COMP.PPL printout. A second reason for the difference is that COMP.PPL includes ammonia and phosphorus (as phosphate) in the ion balance, whereas the balance shown on the NWIS printout does not. Lastly, the COMP.PPL ion balance is calculated with milliequivalents of iron based on the dissolved oxygen (DO) value. If DO is less than $1.5 \mathrm{mg} / \mathrm{L}$, it uses the "+2" oxidation state of iron for calculations; if DO is $1.5 \mathrm{mg} / \mathrm{L}$ or more, it uses the " $+3 "$ oxidation state. In contrast, the ion balance on the NWIS printout is calculated with a default oxidation state for iron; this method is not accurate for many environmental conditions. 
The inclusion of $\mathrm{H}+$ in the ion balance becomes a factor in low-ionic-strength low $\mathrm{pH}$ water in which there is a high concentration of $\mathrm{H}+$ and low concentrations of other cations. For some analyses of this type of water, the ion-balance percent difference on the NWIS printout of laboratory and field data is a high negative value (greater than the acceptable ranges in table 2), but it is not flagged by the COMP.PPL program. If it is not flagged on the COMP.PPL printout, then no action is needed.

\section{SUM OF CONSTITUENTS DIVIDED BY LABORATORY SPECIFIC CONDUCTANCE}

\section{Test name.-- SUM/LSC}

Calculation.-- The sum of major dissolved constituents (SUM) calculated by the program is divided by laboratory-measured specific conductance in microsiemens per centimeter at 25 degrees Celsius. The SUM includes all ions used in the program's calculation of cation-anion balance (PERCENT DIFF) as well as silica, in milligrams per liter reported as silicon dioxide (SiO2) and dissolved organic carbon (DOC).

\section{Parameter codes}

Dissolved calcium, 00915

Dissolved magnesium, 00925

Dissolved sodium, 00930

Dissolved potassium, 00935

Dissolved fluoride, 00950

Dissolved iron, 01046

Dissolved silica, 00955

Dissolved manganese, 01056

Dissolved ammonia, 00608

$\mathrm{pH}$, standard PH units, 00400 (field) or 00403 (laboratory)

Dissolved chloride, 00940

Dissolved sulfate, 00945

Dissolved carbonate, 00452, and dissolved bicarbonate, 00453 (or field alkalinity,
39086, or laboratory ANC, 90410)

Dissolved nitrite, 00613

Dissolved nitrite plus nitrate, 00631

Dissolved phosphorus, 00666 (or dissolved phosphorus, orthophosphate, 00671)

Dissolved organic carbon, 00681

Laboratory specific conductance, 90095

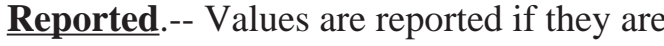
outside the acceptance range of 0.45 to 0.81 . In low-ionic-strength water (specific conductance (SC) less than $75 \mu \mathrm{S} / \mathrm{cm}$ ), an acceptance range of 0.40 to 0.81 is used.

Comments.-- The range of typical values for the ratio in both surface and ground water in New Jersey is 0.45 to 0.81 . For low-ionic-strength water, the lower limit of the range is set at 0.40 . Values outside of this range indicate a possible error in determination of a major ion or in the laboratory SC.

If a value is missing for a mandatory constituent in this test (if it is not stored in the database), the computation of SUM/LSC is not performed. The mandatory constituents for the calculation are $\mathrm{Ca}, \mathrm{Mg}, \mathrm{Na}, \mathrm{K}, \mathrm{Cl}, \mathrm{SO} 4, \mathrm{~F}, \mathrm{SiO} 2$, one of ANC, field alkalinity, bicarbonate, or carbonate, and dissolved NH4, dissolved NO2, and dissolved NO3.

\section{RESIDUE ON EVAPORATION (ROE) DIVIDED BY THE SUM OF MAJOR DISSOLVED CONSTITUENTS (SUM)}

\section{Test name.-- ROE/SUM}

Calculation.-- Solids, residue on evaporation at 180 degrees Celsius (ROE) divided by the sum of major dissolved constituents (SUM). The components used in the SUM calculation are the ones used in the cation-anion balance with the addition of silica as $\mathrm{SiO} 2$ and dissolved organic carbon. 


\section{Parameter codes}

Solids, residue on evaporation at 180 degrees Celsius, 70300

Dissolved calcium, 00915

Dissolved magnesium, 00925

Dissolved sodium, 00930

Dissolved potassium, 00935

Dissolved fluoride, 00950

Dissolved iron, 01046

Dissolved silica, 00955

Dissolved manganese, 01056

Dissolved ammonia, 00608

$\mathrm{pH}$, standard $\mathrm{pH}$ units, 00400 (field) or

00403 (laboratory)

Dissolved chloride, 00940

Dissolved sulfate, 00945

Dissolved carbonate, 00452

Dissolved bicarbonate, 00453

Dissolved nitrite, 00613

Dissolved nitrite plus nitrate, 00631

Dissolved phosphorus, 00666 (or dissolved phosphorus, orthophosphate, 00671)

Dissolved organic carbon, 00681

Laboratory ANC, 90410

Reported.-- For high ionic-strength waters (specific conductance (SC) greater than $100 \mu \mathrm{S} / \mathrm{cm}$ ), the test identifies values of ROE less than 0.9 times the SUM, or ROE greater than SUM plus dissolved organic carbon plus a constant of 21. For low-ionic-strength waters (SC less than $75 \mu \mathrm{S} / \mathrm{cm}$ ), the test is modified to allow ROE to be as much as $10 \mathrm{mg} / \mathrm{L}$ less than SUM. In both cases, if the test limit is exceeded, the ratio $\mathrm{ROE} / \mathrm{SUM}$ is printed.

Comments.-- The test includes DOC, which is not included in the calculation of the sum of dissolved constituents but would be a measurable part of residue by evaporation at $180{ }^{\circ} \mathrm{C}$. The constant 21 was determined by an evaluation of hundreds of samples collected throughout New Jersey.

This ratio is designed to test the accuracy of the ROE value. Generally, ROE is not rerun if a problem occurs with ROE/SUM because the ROE analysis is not very precise. A rerun of ROE is requested if ROE/SUM is more than 2.0 at a site with low-ionic-strength water or more than 1.25 at a site with SC greater than $100 \mu \mathrm{S} / \mathrm{cm}$. When the $\mathrm{SC}$ is below $75 \mu \mathrm{S} / \mathrm{cm}$, as it is at New Jersey Pine Barrens sites, the ROE/SUM ratio will often indicate a potential problem. The New Jersey Pine Barrens is an area with acidic and nutrient-poor, quartz sand soils that drain readily. Ground water and surface water in this area have low ionic strength and DOC values of approximately 3 to 5 $\mathrm{mg} / \mathrm{L}$. For more about ROE and SUM, see the section "QWOUTLIERS PRINTOUT."

\section{PH, DIFFERENCE BETWEEN FIELD AND LABORATORY MEASUREMENTS}

Test name.-- PH DIF

$\underline{\text { Calculation.-- Field pH - laboratory } \mathrm{pH} .}$

\section{Parameter codes}

Field $\mathrm{pH}, 00400$

Laboratory pH, 00403

Reported.-- The difference is reported if it is greater than 1 standard $\mathrm{pH}$ unit.

Comments.-- In low ionic-strength water with the SC less than $75 \mu \mathrm{S} / \mathrm{cm}$, the field measurement of $\mathrm{pH}$ is highly variable, and a low-level ionic strength $\mathrm{pH}$ measurement should be requested from the laboratory when the samples are submitted.

Algal blooms can cause field $\mathrm{pH}$ values that are relatively high compared with historic values at a sampling site as well as supersaturated dissolved oxygen values in samples collected 
between 9 a.m. and 4 p.m. Sites at or immediately downstream from lakes are likely to be affected by algal blooms. In the absence of light (at night as well as during sample shipment to the laboratory), the algae give off carbon dioxide, causing a decrease in the $\mathrm{pH}$. Because the $\mathrm{pH}$ changes between the field measurement and laboratory analysis, a rerun of laboratory $\mathrm{pH}$ would simply duplicate the laboratory value. In cases such as this example of algal bloom, it is acceptable to keep both values in the database even when they differ by 1.0 unit or more. Field measurements, such as $\mathrm{pH}$ and $\mathrm{SC}$, are never deleted from the database or have a DQI reset to Q unless they are obviously incorrect measurements.

When trying to determine whether a laboratory or field $\mathrm{pH}$ is incorrect, the relation between $\mathrm{pH}$ and field alkalinity or laboratory ANC is considered. In general, the higher the $\mathrm{pH}$, the higher the laboratory ANC or field alkalinity, although $\mathrm{pH}$ and $\mathrm{ANC}$ can change by the time the sample is analyzed in the laboratory. In general, field measurements provide the more reliable results. The following examples of how $\mathrm{pH}$ varies with ANC (or alkalinity) are from data for New Jersey streams.

ANC is usually 0 at $\mathrm{pH}$ of 4.5 or below.

ANC of less than 9 is a low value and usually is associated with a pH less than 6 .

ANC would be about 10 if $\mathrm{pH}$ were about 6 .

ANC of 40 to $50 \mathrm{mg} / \mathrm{L}$ correlates with $\mathrm{pH}$ of about 7.7 for Delaware River (New Jersey District) water samples.

\section{SPECIFIC CONDUCTANCE, DIFFERENCE BETWEEN FIELD AND LABORATORY MEASUREMENTS}

\section{Test name.-- SC DIF}

Calculation.-- The ratio, in percent, of field specific conductance (FSC) to laboratory specific conductance (LSC) is calculated. If FSC is greater than $100 \mu \mathrm{S} / \mathrm{cm}$, the difference of FSC - LSC also is calculated.

\section{Parameter codes}

Field specific conductance, 00095

Laboratory specific conductance, 90095.

Reported.-- The difference (FSC - LSC) or ratio, in percent, is printed:

for FSC in the range of 1 to $75 \mu \mathrm{S} / \mathrm{cm}$, if the difference is greater than $20 \mu \mathrm{S} / \mathrm{cm}$;

for FSC in the range of 76 to $100 \mu \mathrm{S} / \mathrm{cm}$, if the difference is greater than $15 \mu \mathrm{S} / \mathrm{cm}$; and

for FSC greater than $100 \mu \mathrm{S} / \mathrm{cm}$, if the ratio is outside the range of 85 to $115 \%$.

Comments.-- If a value is printed in this column, the difference between field and laboratory values for specific conductance is too great. Sometimes it is difficult to tell which is the more accurate of the two values, even when a rerun by the laboratory confirms the laboratory SC. One method used to determine which value is more accurate is to calculate both ROE divided by SC and SUM divided by SC for the laboratory value and for the field value, respectively. The numbers should fall in the range 0.55 to 0.81 . For most sites in New Jersey, ROE divided by SC is the best ratio to use. For sites with low ionicstrength water (SC less than $75 \mu \mathrm{S} / \mathrm{cm}$ ), SUM divided by $\mathrm{SC}$ gives a better indication of which $\mathrm{SC}$ is more accurate.

Regression analysis also can be a useful tool to determine which SC value is more accurate. A regression analysis plot of field $\mathrm{SC}$ in relation to dissolved solids sum is a good visual aid. Ideally, one of these plots is included in a folder maintained for each data-collection site. To create a plot, see the instructions in the section "Regression analysis."

For sites with low ionic-strength water, regression analysis may not work well as an aid in deciding which SC is more accurate. For some sites, such as the Oswego River at Harrisville (01410000) in the New Jersey Pine Barrens, the plots have widely scattered points for which the trend line has a negative slope. (As SUM increases, SC decreases, which is illogical). 
DISSOLVED OXYGEN SATURATION ALERT

\section{Test name.-- DO SAT ALERT}

Calculation.-- Dissolved oxygen saturation (DOSAT), in percent, is compared to limiting values of DOSAT that vary with water temperature.

\section{Parameter codes}

Dissolved oxygen saturation, 00301

Water temperature, 00010

Reported.-- DOSAT is printed when water temperature is less than or equal to $10{ }^{\circ} \mathrm{C}$ and DOSAT is greater than 120 percent, or when water temperature is less than $4.5^{\circ} \mathrm{C}$ and DOSAT is greater than 110 percent or less than or equal to 60 percent.

Comments.-- In a stream, the natural processes of photosynthesis and decomposition occur. Photosynthesis by plants, such as algae, puts additional oxygen into the water. On the other hand, decomposition and algal and microorganism respiration use up dissolved oxygen. The two processes of photosynthesis and decomposition slow down and become negligible as the water temperature nears the freezing point. Therefore, at low water temperatures, the oxygen saturation level is not affected much by these two processes. When water is very cold, the expected percent of the saturation level of oxygen in the water probably is within a range of about 60 to 120 percent. The saturation concentration varies inversely with temperature because cold water holds more oxygen in solution than does warm water.

The DO SAT ALERT test examines the saturation level of oxygen in the water when the temperature is low. In winter, with photosynthesis and decomposition slowed, water colder than $10^{\circ} \mathrm{C}$ generally has a DOSAT level less than 120 percent, and water colder than $4{ }^{\circ} \mathrm{C}$ generally has a DOSAT level of 60 to 110 percent. If these criteria are not satisfied, a value for percent DO saturation is printed.
LOGIC TEST: SUM OF SUSPENDED CONSTITUENTS COMPARED WITH TOTAL SUSPENDED RESIDUE

\section{Test name.-- L.POC.RES}

Calculation.-- If particulate organic carbon (POC) + (total Kjeldahl (KJD) nitrogen - dissolved KJD nitrogen) + 3.066 (total phosphorus -

dissolved phosphorus) $>$ total suspended residue at 105 degrees Celsius, the difference is printed. KJD nitrogen is ammonia as nitrogen plus organic nitrogen.

\section{Parameter codes}

Particulate organic carbon, 00689

Total nitrogen, ammonia plus organic, 00625

Dissolved nitrogen, ammonia plus organic, 00623

Total phosphorus, 00665

Dissolved phosphorus, 00666

Total suspended residue at $105^{\circ} \mathrm{C}, 00530$

Reported.-- If the sum of suspended components is greater than total suspended residue at $105^{\circ} \mathrm{C}$, the difference is printed.

Comments.-- This test compares the sum of several suspended components to total suspended residue at $105^{\circ} \mathrm{C}$. A value is printed if the sum of POC, suspended KJD nitrogen, and suspended phosphorus is greater than the total suspended residue at $105{ }^{\circ} \mathrm{C}$. See the following test, L.SED.RES, for comparison.

\section{LOGIC TEST: SUM OF SUSPENDED CONSTITUENTS COMPARED WITH SUSPENDED SEDIMENT}

\section{Test name.-- L.SED.RES}

Calculation.-- If POC + (total KJD nitrogen dissolved KJD nitrogen) + 3.066 (total phosphorus - dissolved phosphorus) > suspended sediment value, the difference is printed. 


\section{Parameter codes}

Particulate organic carbon, 00689

Total nitrogen, ammonia plus organic, 00625

Dissolved nitrogen, ammonia plus organic, 00623

Total phosphorus, 00665

Dissolved phosphorus, 00666

Suspended sediment, 80154

Reported.-- If the sum of suspended constituents is greater than the suspended sediment value, the difference is printed.

Comments.-- This test is virtually the same as the preceding test (L.POC.RES). The only difference is that it compares the sum of suspended components to the suspended sediment value instead of to the total suspended residue at $105^{\circ} \mathrm{C}$.

\section{LOGIC TEST: DISSOLVED AMMONIA AS NITROGEN COMPARED WITH TOTAL AMMONIA AS NITROGEN}

\section{Test name.-- L.NH4.DT}

Calculation.-- Dissolved ammonia as nitrogen - total ammonia as nitrogen.

\section{Parameter codes}

Dissolved ammonia as nitrogen, 00608

Total ammonia as nitrogen, 00610

Reported.-- When the concentration of dissolved ammonia is equal to or greater than 1 $\mathrm{mg} / \mathrm{L}$, differences greater than $+0.2 \mathrm{mg} / \mathrm{L}$ are printed. Also, when the concentration of dissolved ammonia is less than $1 \mathrm{mg} / \mathrm{L}$, differences greater than $+0.1 \mathrm{mg} / \mathrm{L}$ are printed. These criteria are based on long-term observations of constituent values for New Jersey water samples.
LOGIC TEST: DISSOLVED AMMONIA AS NITROGEN PLUS ORGANIC NITROGEN COMPARED WITH TOTAL AMMONIA AS NITROGEN PLUS ORGANIC NITROGEN

Test name.-- L.KJD.DT

Calculation.-- Dissolved ammonia as nitrogen plus organic nitrogen - total ammonia as nitrogen plus organic nitrogen.

\section{Parameter codes}

Dissolved ammonia as nitrogen plus organic nitrogen, 00623

Total ammonia as nitrogen plus organic nitrogen, 00625

Reported.-- When the concentration of dissolved ammonia plus organic nitrogen is equal to or greater than $1 \mathrm{mg} / \mathrm{L}$, differences greater than $+0.3 \mathrm{mg} / \mathrm{L}$ are printed, and when the concentration of dissolved ammonia plus organic nitrogen is less than $1 \mathrm{mg} / \mathrm{L}$, differences greater than $+0.2 \mathrm{mg} / \mathrm{L}$ are printed. These criteria are based on long-term observations of constituent values for New Jersey water samples.

LOGIC TEST: DISSOLVED ORTHOPHOSPHATE COMPARED WITH DISSOLVED PHOSPHORUS

\section{Test name.-- L.PO4.P.D}

Calculation.-- Dissolved orthophosphate dissolved phosphorus.

\section{Parameter codes}

Dissolved orthophosphate, 00671

Dissolved phosphorus, 00666 
Reported.-- When the concentration of dissolved orthophosphate is equal to or greater than $1 \mathrm{mg} / \mathrm{L}$, differences greater than $+0.1 \mathrm{mg} / \mathrm{L}$ are printed, and when the concentration of dissolved orthophosphate is less than $1 \mathrm{mg} / \mathrm{L}$, differences greater than $+0.03 \mathrm{mg} / \mathrm{L}$ are printed. These criteria are based on long-term observations of constituent values for New Jersey water samples.

Comments.-- A value is printed for L.PO4.P.D when the concentration of dissolved orthophosphate (PO4) exceeds the concentration of dissolved phosphorus (P) by more than an allowable amount. See discussion in "Logic test: dissolved orthophosphate compared with total phosphorus" (L.ORTHO.P.DT).

\section{LOGIC TEST: DISSOLVED PHOSPHORUS COMPARED WITH TOTAL PHOSPHORUS}

Test name.-- L.P.DT

Calculation.-- Dissolved phosphorus - total phosphorus.

\section{Parameter codes}

Dissolved phosphorus, 00666

Total phosphorus, 00665

Reported.-- When concentrations of dissolved phosphorus are equal to or greater than $1 \mathrm{mg} / \mathrm{L}$, differences greater than $+0.2 \mathrm{mg} / \mathrm{L}$ are printed; when concentrations of dissolved phosphorus are less than $1 \mathrm{mg} / \mathrm{L}$, differences greater than +0.05 $\mathrm{mg} / \mathrm{L}$ are printed. These criteria are based on longterm observations of constituent values for New Jersey water samples.

Comments.-- A value is printed for L.P.DT when dissolved $\mathrm{P}$ exceeds total $\mathrm{P}$ by more than an allowable amount. See discussion in "Logic test: dissolved orthophosphate compared with total phosphorus" (L.ORTHO.P.DT) for relations between dissolved P, total P, and dissolved PO4.
LOGIC TEST: DISSOLVED ORTHOPHOSPHATE COMPARED WITH TOTAL PHOSPHORUS

Test name.-- L.ORTHO.P.DT

Calculation.-- Dissolved orthophosphate - total phosphorus.

\section{Parameter codes}

Dissolved orthophosphate, 00671

Total phosphorus, 00665

Reported.-- When the concentration of PO4 is equal to or greater than $1 \mathrm{mg} / \mathrm{L}$, differences greater than $+0.2 \mathrm{mg} / \mathrm{L}$ are printed, and when the concentration of PO4 is less than $1 \mathrm{mg} / \mathrm{L}$, differences greater than $+0.03 \mathrm{mg} / \mathrm{L}$ are printed. These criteria are based on long-term observations of constituent values for New Jersey water samples.

Comments.-- This test and the Logic test: dissolved orthophosphate compared with dissolved phosphorus (L.PO4.P.D) (see above) both involve the relation between $\mathrm{P}$ and PO4. All PO4 is dissolved because it exists only in the ionic form. Dissolved PO4 is a part of dissolved P and total $\mathrm{P}$ and, therefore, should not be greater than either of them. The acceptable range for dissolved PO4 is 92 percent to 103 percent of dissolved $\mathrm{P}$. If dissolved PO4 is more than 103 percent of dissolved $\mathrm{P}$, a problem has occurred in the laboratory analysis. Consider a reanalysis of one or both constituents.

Of particular interest is that the concentrations of dissolved and total $\mathrm{P}$ are determined in the laboratory by a digestion process which converts all the $\mathrm{P}$ into PO4. If a value is printed for L.ORTHO.P.DT, the difference between concentrations of dissolved PO4 and total P is too great. 
LOGIC TEST: INORGANIC CARBON IN STREAMBED MATERIAL COMPARED WITH TOTAL CARBON IN STREAMBED MATERIAL

\section{Test name.-- L.BTM.CIN.CTOT}

Calculation.-- Inorganic carbon $(\mathrm{C})$ in streambed material - total $\mathrm{C}$ in streambed material.

\section{Parameter codes}

Inorganic carbon in streambed material (grams per kilogram), 00686

Total (inorganic plus organic) carbon in streambed material (grams per kilogram), 00693

Reported.-- When the concentration of inorganic $\mathrm{C}$ is greater than the concentration of total $\mathrm{C}$, the difference is printed.

\section{LOGIC TEST: DISSOLVED NITRITE AS NITROGEN COMPARED WITH DISSOLVED NITRITE PLUS NITRATE AS NITROGEN}

Test name.-- L.NO2.NO2NO3.D

Calculation.-- Dissolved nitrite as nitrogen dissolved nitrite plus nitrate as nitrogen.

\section{Parameter codes}

Dissolved nitrite as nitrogen, 00613

Dissolved nitrite plus nitrate as nitrogen, 00631

Reported.-- When the nitrite (NO2) concentration is more than $0.03 \mathrm{mg} / \mathrm{L}$ greater than the nitrite plus nitrate $(\mathrm{NO} 2+\mathrm{NO} 3)$ concentration, the difference is printed.

LOGIC TEST: DISSOLVED AMMONIA AS NITROGEN COMPARED WITH DISSOLVED AMMONIA AS NITROGEN PLUS ORGANIC NITROGEN

Test name.-- L.NH4.TKN.D
Calculation.-- Dissolved ammonia as nitrogen - dissolved ammonia as nitrogen plus organic nitrogen.

\section{Parameter codes}

Dissolved ammonia as nitrogen, 00608

Dissolved ammonia as nitrogen plus organic nitrogen, 00623

Reported.-- When the concentration of dissolved ammonia is equal to or greater than 1 $\mathrm{mg} / \mathrm{L}$, differences greater than $+0.2 \mathrm{mg} / \mathrm{L}$ are printed, and when dissolved ammonia concentration is less than $1 \mathrm{mg} / \mathrm{L}$, differences greater than $+0.07 \mathrm{mg} / \mathrm{L}$ are printed. These criteria are based on long-term observations of constituent values for New Jersey water samples.

\section{LOGIC TEST: TOTAL AMMONIA AS NITROGEN COMPARED WITH TOTAL AMMONIA AS NITROGEN PLUS ORGANIC NITROGEN}

\section{Test name.-- L.NH4.TKN.T}

Calculation.-- Total ammonia as nitrogen total ammonia as nitrogen plus organic nitrogen.

\section{Parameter codes}

Total ammonia as nitrogen, 00610

Total ammonia as nitrogen plus organic nitrogen, 00625

Reported.-- When the concentration of total ammonia is equal to or greater than $1 \mathrm{mg} / \mathrm{L}$, differences greater than $+0.2 \mathrm{mg} / \mathrm{L}$ are printed, and when the concentration of total ammonia is less than $1 \mathrm{mg} / \mathrm{L}$, differences greater than $+0.1 \mathrm{mg} / \mathrm{L}$ are printed. These criteria are based on long-term observations of constituent values for New Jersey water samples. 
LOGIC TEST: DISSOLVED AMMONIA AS NITROGEN COMPARED WITH TOTAL AMMONIA AS NITROGEN PLUS ORGANIC NITROGEN

\section{Test name.-- L.NH4.TKN.DT}

Calculation.-- Dissolved ammonia as nitrogen - total ammonia as nitrogen plus organic nitrogen.

\section{Parameter codes}

Dissolved ammonia as nitrogen, 00608

Total ammonia as nitrogen plus organic nitrogen, 00625

Reported.-- When the concentration of dissolved ammonia is equal to or greater than 1 $\mathrm{mg} / \mathrm{L}$, differences greater than $+0.2 \mathrm{mg} / \mathrm{L}$ are printed, and when the concentration of dissolved ammonia is less than $1 \mathrm{mg} / \mathrm{L}$, differences greater than $+0.1 \mathrm{mg} / \mathrm{L}$ are printed. These criteria are based on long-term observations of constituent values for New Jersey water samples.

\section{SODIUM - POTASSIUM WARNING}

\section{Test name.-- NA.K.WARNING}

Calculation.-- Potassium minus sodium.

\section{Parameter codes}

Dissolved sodium, 00930

Dissolved potassium 00935

Reported.-- For samples in which the concentration of potassium $(\mathrm{K})$ is greater than 10 and the concentration of sodium $(\mathrm{Na})$ is less than that of $\mathrm{K}$, the difference between $\mathrm{Na}$ and $\mathrm{K}$ is printed.

Comments.-- Sample analyses that fail this test are rare. The test is failed when the concentration of $\mathrm{K}$ is more than $10 \mathrm{mg} / \mathrm{L}$ and the concentration of $\mathrm{Na}$ is less than that of $\mathrm{K}$. This sometimes occurs naturally at sites with low-ionic-strength water; if it occurs at other sites, consider requesting the laboratory to reanalyze $\mathrm{Na}$ and $\mathrm{K}$.
When rocks are weathered, Na tends to remain in solution; however, $\mathrm{K}$ is less soluble. After $\mathrm{K}$ is dissolved, it tends to be reincorporated into solid weathering products and also is taken up by plants as a nutrient (Hem, 1992, p. 104).

According to Hem (1992, p. 104-105), in lowionic-strength water in which the sum of $\mathrm{Na}$ and $\mathrm{K}$ is less than $10 \mathrm{mg} / \mathrm{L}$, the $\mathrm{K}$ concentration may equal or exceed the Na concentration. In most freshwater aquifers, if the $\mathrm{Na}$ concentration substantially exceeds $10 \mathrm{mg} / \mathrm{L}$, the $\mathrm{K}$ concentration commonly is a fraction of the $\mathrm{Na}$ concentration. More than a few tens of milligrams per liter of $\mathrm{K}$ is unusual except in water with a high dissolved solids concentration or in water from hot springs.

\section{DISSOLVED NITRITE AS NITROGEN AND PERCENT SATURATION DISSOLVED OXYGEN}

\section{Test name.-- NO2.DIS DO}

Calculation.-- The ratio of nitrite as nitrogen to nitrite plus nitrate as nitrogen is calculated and evaluated against dissolved oxygen as a percent of saturation.

\section{Parameter codes}

Dissolved nitrite as nitrogen, 00613

Dissolved nitrite plus nitrate as nitrogen, 00631

Dissolved oxygen, percent saturation, 00301

Reported.-- The percent ratio of nitrite (NO2) to nitrite plus nitrate $(\mathrm{NO} 2+\mathrm{NO} 3)$ is printed when dissolved oxygen as a percent of saturation is greater than 60 percent and $\mathrm{NO} 2$ is greater than 0.065 of $\mathrm{NO} 2+\mathrm{NO} 3$. These criteria are based on long-term observations of constituent values for New Jersey water samples.

Comments.-- If this test fails, it means the concentration of dissolved $\mathrm{NO} 2$ is too great relative to the dissolved $\mathrm{NO} 3$ concentration. If percent saturation of DO is greater than 60 percent and dissolved NO2 is greater than 6.5 percent of 
combined $\mathrm{NO} 2$ and $\mathrm{NO} 3$, then a value is printed for $\mathrm{NO} 2$ divided by $(\mathrm{NO} 2+\mathrm{NO} 3)$ multiplied by 100 percent.

The 6.5 percent rule is meant to be a general rule of thumb based on historical statistics for local conditions more than a strict rule that must always be observed. The rule does not hold true for low concentrations, for example, when the sum of $\mathrm{NO} 2+\mathrm{NO} 3$ is less than $0.1 \mathrm{mg} / \mathrm{L}$. When the values fail the test and concentrations are less than $0.1 \mathrm{mg} / \mathrm{L}$, make the following checks before dismissing the infraction. Be sure that dissolved $\mathrm{NO} 2$ is about equal to total $\mathrm{NO} 2$ if both values are available, and check the correctness of data entry for field values of SC, temperature, DO, and barometric pressure, which all affect percent oxygen saturation that, in turn, is a key to the test.

At sampling sites near which waterfowl are commonly found or where algae are abundant, $\mathrm{NO} 2$ could be a large part of $\mathrm{NO} 2+\mathrm{NO} 3$. Values as high as 43 percent have been observed at sites in New Jersey.

When both NO2 and NO3 are low and are at or below the minimum reporting level (MRL), as in water with low ionic strength, they often appear to fail this test with a high percentage value shown in the program output. For example, if $\mathrm{NO} 2$ is less than the MRL in water year ${ }^{3} 2002$ of $0.003 \mathrm{mg} / \mathrm{L}$ and $\mathrm{NO} 2+\mathrm{NO} 3$ is less than the MRL in water year 2002 of $0.037 \mathrm{mg} / \mathrm{L}$, then the program makes the computation

$$
\mathrm{NO} 2 /(\mathrm{NO} 2+\mathrm{NO} 3)=0.003 / 0.037=8.1 \text { percent },
$$

which is higher than the allowed 6.5 percent. This would seem at first glance to be a problem; however, the 8.1-percent value is simply a result of both values being close to their reporting levels. The percentage depends, of course, on the reporting levels of the respective constituents. These kinds of numbers will appear frequently in samples from New Jersey sites with low-ionicstrength water in which concentrations of all ions are extremely low. The reviewer can allow infractions of this type at such low concentrations.

\section{DISSOLVED NITRITE PLUS NITRATE AS NITROGEN, AND DISSOLVED OXYGEN}

\section{Test name.-- NO2NO3.DIS DO}

Calculation.-- Dissolved nitrite plus nitrate as nitrogen is evaluated against dissolved oxygen.

\section{$\underline{\text { Parameter Codes }}$}

Dissolved nitrite plus nitrate nitrogen, 00631

Dissolved oxygen, 00300

Reported.-- The concentration of dissolved nitrite plus nitrate nitrogen is printed if it is greater than 0.05 and dissolved oxygen is less than 1.5.

Comments.-- At low values of dissolved oxygen, nitrogen will generally be present as dissolved nitrogen gas, nitrite, or the ammonium ion $\mathrm{NH} 3+$, not as nitrate. For the test, it is assumed that $\mathrm{NO} 2$ is a small fraction of $\mathrm{NO} 2+\mathrm{NO} 3$ when the DO concentration is greater than $1.5 \mathrm{mg} / \mathrm{L}$. The test is failed and a value is printed for dissolved NO2 + NO3 if (1) DO is less than 1.5 $\mathrm{mg} / \mathrm{L}$ and (2) dissolved $\mathrm{NO} 2+\mathrm{NO} 3$ is greater than $0.05 \mathrm{mg} / \mathrm{L}$.

\section{MAGNESIUM TO CALCIUM RATIO WARNING}

\section{Test name.-- CA MG RATIO WARN}

Calculation.-- The ratio of milliequivalent concentrations of magnesium to calcium is calculated.

\footnotetext{
${ }^{3}$ Water year in USGS reports is the 12-month period from October 1 through September 30. The water year is designated by the calendar year in which it ends and which includes 9 of the 12 months. Thus, the year ending September 30, 2002, is called "water year 2002."
} 


\section{Parameter codes}

Dissolved calcium, 00915

Dissolved magnesium, 00925

Reported.-- The ratio is printed if it is greater than 1 .

Comments.-- The value shown in the program output for this test is equivalent to the molar ratio of milliequivalents per liter (meq/L) of magnesium $(\mathrm{Mg})$ to $\mathrm{meq} / \mathrm{L}$ of calcium $(\mathrm{Ca})$. It is not the mass ratio of $\mathrm{Ca}$ to $\mathrm{Mg}$ as the title suggests. This test is failed if the ratio is greater than 1 . This value is based on the ratio of $\mathrm{Mg}$ to $\mathrm{Ca}$ found in the rock dolomite.

For sites with moderate to high SC $(100 \mu \mathrm{S} / \mathrm{cm}$ or higher), this ratio should always be less than 1 . If it is 1 or more, consider requesting reanalyses of $\mathrm{Ca}$ and $\mathrm{Mg}$. If the ratio is much greater than 1, consider requesting reanalyses of all cations.

Surface-water samples from sites with lowionic-strength water and some ground-water samples might have $\mathrm{Mg}$ to $\mathrm{Ca}$ ratios greater than 1 . The values for $\mathrm{Ca}$ and $\mathrm{Mg}$, however, will be quite low so that small changes in either $\mathrm{Mg}$ or $\mathrm{Ca}$ can cause big changes in the ratio. When the actual $\mathrm{Mg}$ and $\mathrm{Ca}$ values are low, for example $\mathrm{Mg}$ of 3.2 and $\mathrm{Ca}$ of 4.9, this test is not accurate, and there is little need to investigate further. For sites with low-ionic-strength water, $\mathrm{Mg}$ to $\mathrm{Ca}$ ratios as high as 1.8 or more can be allowed.

\section{NEW JERSEY DRINKING-WATER STANDARDS}

Test name.-- Various similar alert tests which have names beginning with $\mathrm{A}$, followed by a constituent name, followed by an abbreviated form of its parameter code. The test names and the constituents tested are given in table 3 .

Calculation.-- Each constituent is compared with the NJDEP drinking-water standards (Shelton, 1996) except for silver (Ag) and zinc (Zn), which are compared with the U.S. Environmental Protection Agency (USEPA) drinking-water standards (U.S. Geological Survey, 2001, appendix E).

Reported.-- Values greater than the standard are printed.

Comments.-- In general, the NJDEP standards are more stringent than the USEPA standards. The program tests for dissolved NO2 + NO3, dissolved fluoride, and various dissolved and total trace elements. In the test name A.ARS.DIS.P1000, the beginning A stands for alert test, ARS for arsenic, DIS for dissolved (as opposed to TOT for total), and P1000 for parameter code 01000 . If a value is printed for one of these tests in the program output, it is the constituent concentration and indicates that the value is greater than drinkingwater standards.

For samples from untreated sources of water not used for drinking water, if a value appears in a column for a parameter code and that value is also an outlier, ask for a rerun. If the value appears only as an ALERT, but not as an outlier (see section below about outliers), further investigation is not needed. This situation indicates that the constituent is sometimes present at high levels at the site, although it is greater than drinking-water standards.

For samples from untreated sources of water used for drinking water, if a value appears in an ALERT column for a constituent, the laboratory that performed the analysis of that constituent will be asked to rerun the analysis.

\section{FIELD ALKALINITY COMPARED WITH LABORATORY ANC, SURFACE-WATER SAMPLES}

\section{Test name.-- ALK SW}

Calculation.-- The ratio of field value of alkalinity, in milligrams per liter as calcium carbonate $(\mathrm{CaCO} 3)$, to laboratory value of ANC (acid neutralizing capacity, previously called alkalinity), in milligrams per liter as $\mathrm{CaCO} 3$, is calculated. 
Table 3. Tests for comparison of constituent concentrations with New Jersey drinking-water standards [Silver and zinc concentrations are compared to U.S. Environmental Protection Agency drinking-water standards. mg/l, milligrams per liter; $\mu \mathrm{g} / \mathrm{L}$, micrograms per liter; MCL, maximum contaminant level]

\begin{tabular}{|c|c|c|}
\hline Test name & Constituent & Standard \\
\hline A.NO2NO3.D.P631 & Nitrite plus nitrate, dissolved & $10 \mathrm{mg} / \mathrm{L}$ \\
\hline A.F.DIS.P950 & Fluoride, dissolved & $4 \mathrm{mg} / \mathrm{L}$ \\
\hline A.ARS.DIS.P1000 & Arsenic, dissolved & $10 \mu \mathrm{g} / \mathrm{L}$ \\
\hline A.ARS.TOT.REC.P1002 & Arsenic, total recoverable & $10 \mu \mathrm{g} / \mathrm{L}$ \\
\hline A.BA.DIS.P1005 & Barium, dissolved & $2,000 \mu \mathrm{g} / \mathrm{L}$ \\
\hline A.CD.DIS.P1025 & Cadmium, dissolved & $5 \mu \mathrm{g} / \mathrm{L}$ \\
\hline A.CD.TOT.REC.P1027 & Cadmium, total recoverable & $5 \mu \mathrm{g} / \mathrm{L}$ \\
\hline A.CR.DIS.P1030 & Chromium, dissolved & $100 \mu \mathrm{g} / \mathrm{L}$ \\
\hline A.CR.TOT.REC.P1034 & Chromium, total recoverable & $100 \mu \mathrm{g} / \mathrm{L}$ \\
\hline A.CU.DIS.P1040 & Copper, dissolved & $1,300 \mu \mathrm{g} / \mathrm{L}$ (action level) \\
\hline A.CU.TOT.REC.P1042 & Copper, total recoverable & $1,300 \mu \mathrm{g} / \mathrm{L}$ (action level) \\
\hline A.PB.DIS.P1049 & Lead, dissolved & $15 \mu \mathrm{g} / \mathrm{L}$ (action level) \\
\hline A.PB.TOT.REC.P1051 & Lead, total recoverable & $15 \mu \mathrm{g} / \mathrm{L}$ (action level) \\
\hline A.AG.DIS.P1075 & Silver, dissolved (secondary MCL) & $100 \mu \mathrm{g} / \mathrm{L}$ \\
\hline A.ZN.DIS.P1090 & Zinc, dissolved (secondary MCL) & $5,000 \mu \mathrm{g} / \mathrm{L}$ \\
\hline A.ZN.TOT.REC.P1092 & Zinc, total recoverable (secondary MCL) & $5,000 \mu \mathrm{g} / \mathrm{L}$ \\
\hline A.SE.DIS.P1145 & Selenium, dissolved & $50 \mu \mathrm{g} / \mathrm{L}$ \\
\hline A.SE.TOT.REC.P1147 & Selenium, total recoverable & $50 \mu \mathrm{g} / \mathrm{L}$ \\
\hline A.HG.DIS.P71890 & Mercury, dissolved & $2 \mu \mathrm{g} / \mathrm{L}$ \\
\hline A.HG.TOT.REC.P71900 & Mercury, total recoverable & $2 \mu \mathrm{g} / \mathrm{L}$ \\
\hline
\end{tabular}




\section{Parameter codes}

Field determined alkalinity, 39086

Laboratory determined acid neutralizing capacity, 90410

Reported.-- Ratios outside the range of 0.9 to 1.1 are printed.

Comments.-- An entry in this column means the values for field alkalinity and laboratory ANC are too different. If field alkalinity differs from laboratory ANC by more than 10 percent, then the ratio of field alkalinity to laboratory ANC is printed.

ANC, or alkalinity, is looked at in conjunction with $\mathrm{pH}$ because they are all related to the amount of acid-buffering capacity (or the lack thereof). The following associations between $\mathrm{ANC}$ and $\mathrm{pH}$ have been observed for New Jersey streams.

ANC typically is less than $1 \mathrm{mg} / \mathrm{L}$ at $\mathrm{pH}$ of 4.5 or less.

Laboratory reporting limit for ANC is $1 \mathrm{mg} / \mathrm{L}$.

ANC of less than 9 is a low value and typically is associated with a $\mathrm{pH}$ less than 6 .

ANC would be about 10 if $\mathrm{pH}$ were about 6 .

ANC of 40 to $50 \mathrm{mg} / \mathrm{L}$ correlates with a $\mathrm{pH}$ of about 7.7.
At lower values of ANC or alkalinity, 20 to $30 \mathrm{mg} / \mathrm{L}$ or less, the reviewer can be more lenient in allowing the field and laboratory values to differ. ANC and alkalinity values are accurate to $\pm 1 \mathrm{mg} / \mathrm{L}$. As the measured values become smaller, the measurement difference becomes a larger percentage of the measured value. Low measured values (less than $5 \mathrm{mg} / \mathrm{L}$ in New Jersey streams) occur for sites with low-ionic-strength water (specific conductance less than $75 \mu \mathrm{S} / \mathrm{cm}$ ), but a discrepancy of $\pm 1 \mathrm{mg} / \mathrm{L}$ between field and laboratory values is acceptable for low-ionicstrength waters.

ANC or alkalinity can change considerably between the time the field measurement was made and the time of laboratory analysis. This is especially true if an elevated field $\mathrm{pH}$ was due to algal activity.

If the field titration, which measures field alkalinity, is determined to be unacceptable and the field alkalinity value (PC 39086) is deleted, then all values that come from the same titration are unacceptable. In this case, the following values should be deleted or marked in the NWIS database as having been reviewed and rejected (specify the data-quality indicator as Q):

Field alkalinity (PC 39086),

Field bicarbonate (PC 00453), and

Field carbonate ( $\mathrm{PC} \mathrm{00452)} \mathrm{if} \mathrm{pH}$ is greater than 8.3. 


\section{Guidelines for Review of Nutrients}

Small infractions can be allowed in cases in which the dissolved value of a nutrient is greater than the total value or a part is greater than the whole, especially if the numbers are small. Infractions also can be allowed if the numbers are large, but the ion-balance percent difference is rather small. The following values can be used as guidelines (all values are in $\mathrm{mg} / \mathrm{L}$ ).

Acceptable infractions:

Dissolved P of $0.06>$ total $\mathrm{P}$ of 0.02

Dissolved P of $0.11>$ total P of 0.06

Dissolved P of $0.15>$ total P of 0.10

Total NO2+NO3 of $5.97 \neq$ dissolved $\mathrm{NO} 2+\mathrm{NO} 3$ of 5.77

Unacceptable infractions:

Dissolved P of $0.19>$ total P of 0.11

Dissolved P of $0.27>$ total P of 0.16

Dissolved NH4 of $0.18>$ total NH4 of 0.04

Dissolved KJD of $0.40>$ total KJD of 0.15

Dissolved KJD of $0.65>$ total KJD of 0.40

Total NH4 of $0.19>$ total KJD of $(<0.03)$

Dissolved NO2+NO3 of $0.51 \neq$ total $\mathrm{NO} 2+\mathrm{NO} 3$ of 0.35

Dissolved NO2+NO3 of $0.91 \neq$ total $\mathrm{NO} 2+\mathrm{NO} 3$ of 0.65

Borderline cases:

$$
\begin{aligned}
& \text { Dissolved NO2+NO3 of } 3.97 \neq \text { total } \mathrm{NO} 2+\mathrm{NO} 3 \text { of } 4.19 \\
& \text { Dissolved NO2+NO3 of } 0.97 \neq \text { total NO2+NO3 of } 0.80 \\
& \text { Dissolved KJD of } 5.64>\text { total KJD of } 5.14
\end{aligned}
$$

In some cases, both values of an unacceptable pair will look good; both will be within historical ranges and be acceptable values even though a logic problem occurs. If one value is total concentration and one is dissolved concentration, favor deleting the total (unfiltered) value or marking it in the NWIS database as having been reviewed and rejected. Ammonia, nitrite, nitrite plus nitrate, and phosphate are determined by colorimetric methods, and suspended material in the water could reduce the accuracy and precision of the method if the sample is unfiltered. Therefore, analysis of the unfiltered sample is more likely to result in an unacceptable value. 


\section{QWOUTLIERS PRINTOUT}

\section{Outliers in General}

The QWOUTLIER report or printout from COMP.PPL is the product of a comparison of each value in the retrieved data set against the distribution of values for the same analyte at the same site for a period of record. The program output shows the reviewer any analyte values that are outside a historical range of values, which is 1.5 times the interquartile range plus the 75 th percentile value, and the lowest value of the period of record. The values outside the range are called outliers. In New Jersey, the values included in the statistical summary begin with the 1976 water year and include all values that have been published in the District annual report series for a site. The statistics are updated each year shortly after publication of the annual report. An example report is shown in table 4.

Ideally, the reviewer should look for patterns within a single sample and among samples at nearby sites. Collection of samples immediately or soon after a rainfall could result in many high-end outliers for unfiltered analytes or many low-end outliers for filtered analytes. High concentrations of many dissolved constituents also could be the result of unusually low streamflow. A good general rule to keep in mind is that concentrations of dissolved constituents tend to decrease as stream discharge and stage increase, whereas concentrations of total constituents tend to increase as discharge and stage increase.

\section{EXPLANATION OF HEADINGS}

Each sample is identified by station identification number, date, and time and can be represented by multiple lines of output. The headings for the columns in the report are described below.

SEASON.-- The program analyzes the values of most constituents for outliers without regard to seasonal variations, but for some constituents the program compares the present value to past values on the basis of cold (nongrowing) and warm (growing) seasons. This column informs the reviewer, for each constituent listed as an outlier, whether the program is comparing it with all historical values, ALL, or only the values from the WARM or COLD seasons. For each site, the ALL season constituents are listed first in the program output, then the COLD or WARM constituents. Within each seasonal category, constituents are listed in order of their parameter code. The WARM season for New Jersey samples is defined as April 1 to October 31, and the COLD season is November 1 to March 31. The cold season begins on the first day of the month during which the first frost of the year occurred in New Jersey (long-term average) and ends on the last day of the month during which the last frost of the year occurred (long-term average) as reported by Ruffner and Bair (1977). One reason for this seasonal division is that in warm water (higher than $10{ }^{\circ} \mathrm{C}$ ), bacteria oxidize $\mathrm{NH} 4$ to NO2 and NO3 at a faster rate than in cold water. Thus, in warm water, concentrations of $\mathrm{NH} 4$ will tend to be lower, and $\mathrm{NO} 2$ and $\mathrm{NO} 3$ will tend to be greater. In cold water, NH4 will tend to be greater and NO2 and NO3 will tend to be lower (Buxton and others, 1998, 1999a, 1999b; Hunchak-Kariouk and others, 1999). A second reason for the seasonal division is that the concentration of the various species of nitrogen tends to be lower during the non-growing (cold) season than in the growing (warm) season. An exception to this is $\mathrm{NH} 4$, which can be greater in the cold season when the sample is collected downstream from a wastewater-treatment plant. The 20 constituents reported seasonally in this manner are listed below with their parameter codes. This list of seasonally affected constituents is based on the results of the four studies by Buxton and others $(1998,1999 a, 1999 b)$ and Hunchak-Kariouk and others (1999) that relate water quality to streamflow.

00010 Temperature

00300 Dissolved oxygen

00301 Percent dissolved oxygen saturation 00608 NH4, dissolved 


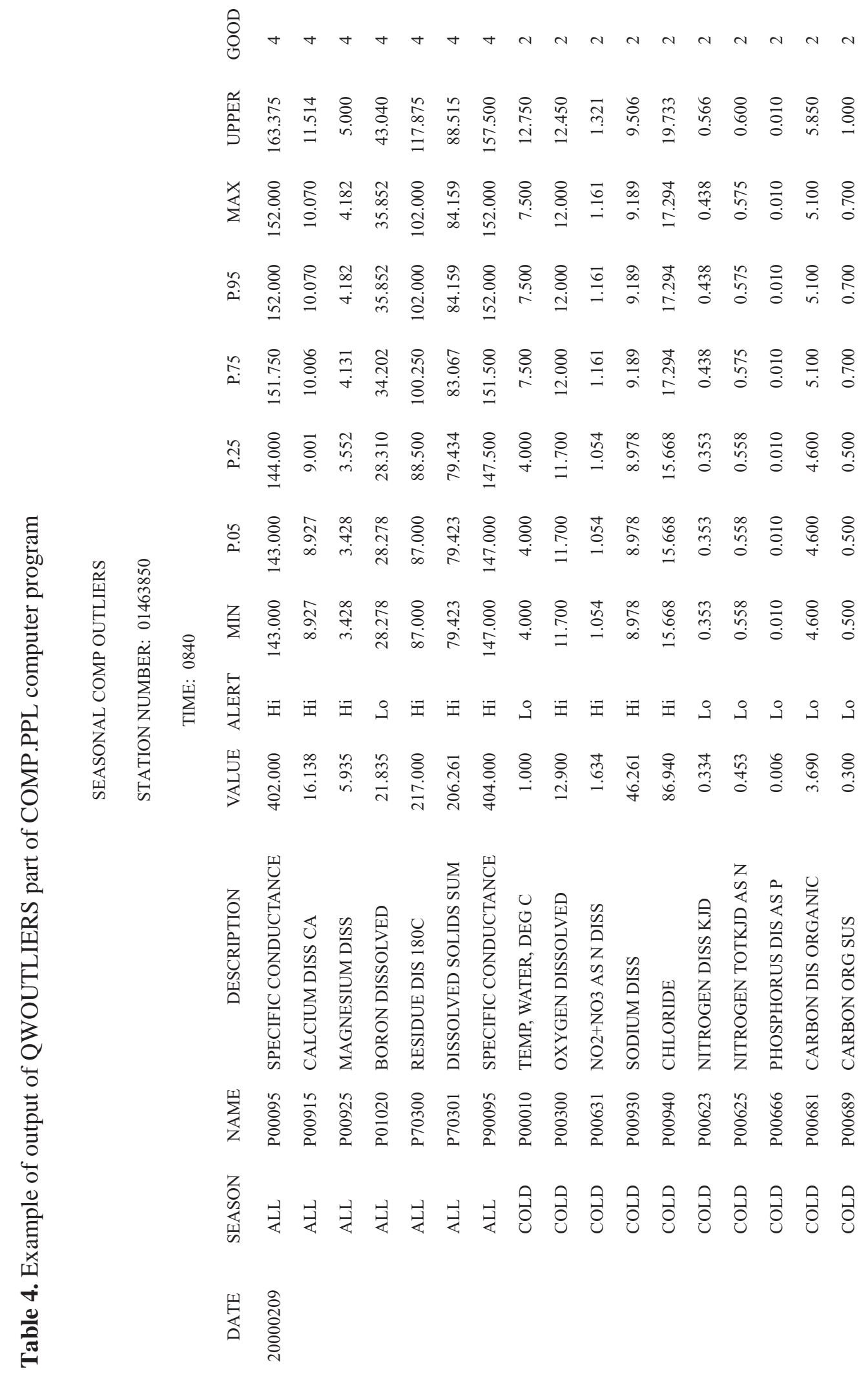




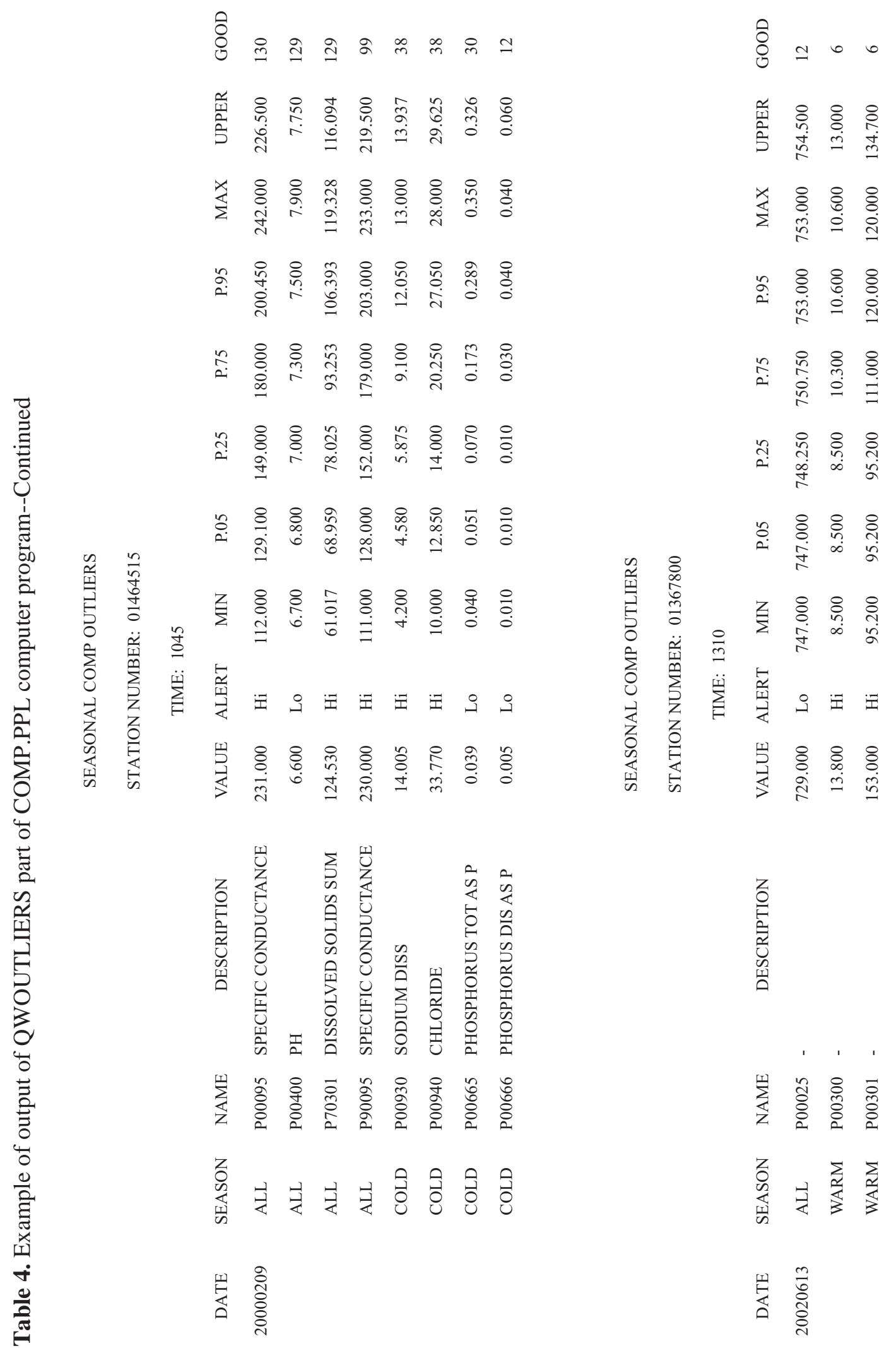




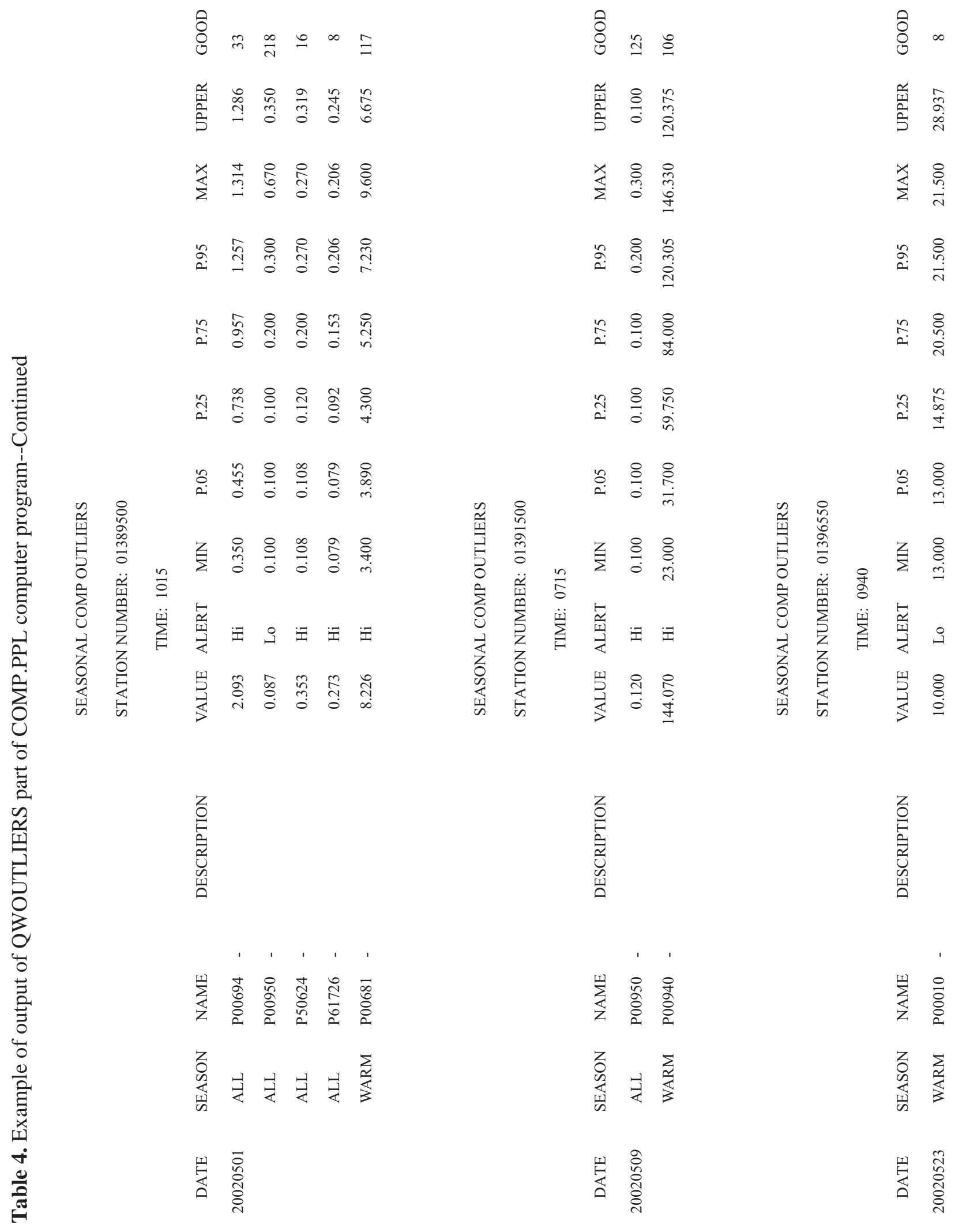


$00610 \mathrm{NH} 4$, total

00613 Nitrite, dissolved

00623 Nitrogen, ammonia plus organic, dissolved

00625 Nitrogen, ammonia plus organic, total

00631 Nitrite + nitrate, dissolved

00665 Phosphorus, total

00666 Phosphorus, dissolved

00680 Total organic carbon

00681 Dissolved organic carbon

00689 Particulate organic carbon

00930 Sodium, dissolved

00940 Chloride, dissolved

31615 Coliform, fecal, EC broth, most probable number

31625 Coliform, fecal, 0.7 micrometer, membrane filtration (colonies/100 mL)

31649 Enterococci M-E media, membrane filtration, water total (colonies/100 mL)

31673 Streptococci, fecal, KF media (colonies/100 mL)

This seasonal data analysis must be used with caution for samples collected near the beginning or end of the two seasons. For these samples, the reviewer looks more at the water temperature than at the season. If there is an outlier for a constituent that is reported by season, first check the water temperature to make sure the COMP.PPL program is comparing the constituent against the correct historical data.

ALERT and UPPER.-- The column headed by ALERT shows whether the value listed is a high or low outlier. This has no relation to the NJDEP and EPA alert limits in the QWREVIEW program output. It shows whether the value is outside the range set by the COMP.PPL program. The lower limit of this range (shown in the MIN column) is the minimum value for the period of record. The upper limit of this range (also called the outer fence limit and shown in the UPPER column) is defined as: 1.5 (P.75 - P.25) + P.75, where P.75 is the 75th percentile value and P.25 is the 25 th percentile value. These upper and lower limits are seasonal limits, where applicable.

MIN, MAX and P values.-- The columns headed by MIN and MAX show the minimum and maximum values in the database for the site for the constituent shown. The columns headed by $\mathrm{P}$ show the various percentiles. For example, P.25 shows the 25 th percentile value. All these are seasonal statistics, where applicable.

Good.-- This column shows the number of previous analyses in the database excluding data that have not yet been published. The higher the number that appears in the Good column, the more seriously the outlier should be considered. When 15 to 20 or more appears in the Good column, the outlier should be taken seriously. If 1 to 10 appears in the column to indicate previous analyses, the outlier may be taken less seriously because there are too few values in the database for a good estimate of the distribution of values. In cases in which the value 5 or less appears in the Good column, the preferred approach is to make a tabular retrieval from the database of all samples for the site regardless of whether or not they have been published, and then compare the current values against historical values in the table.

\section{LOW-END OUTLIERS}

Very seldom is a reanalysis for a constituent requested solely on the basis of low-end outliers unless many values are stored in the database and the questionable value is much less than the previous minimum. Low values can be the result of dilution from rainfall, low-concentration imprecision in the laboratory, or a change in the laboratory lower-reporting level. Of course, if it does appear to be an unreliable value, then a reanalysis should be requested. 
Values for at least eight streambed material (bottom sediment) samples must be stored in the database $(8 \mathrm{Good})$ for the COMP.PPL program to adequately describe the data distribution. If fewer than eight samples are stored, the statistical value of outliers is small. In addition, the COMP.PPL program is not a good tool for use in the review of analyses of streambed sediments because the compositions of solid matrices have more variability than does water; the variability is caused by sampling and analytical methods. The best way to deal with streambed-material analyses is to make a table retrieval from QWDATA of all such analyses in the database for the sites that are being reviewed. Compare current values with historical values shown in the table. If a current value seems unusually high or low, compare it with the value for the same constituent in the water column analysis, if that is available. Reanalyses of trace elements in streambedmaterial samples can be requested from the National Water Quality Laboratory (NWQL). Typically, reanalyses of nutrients and organic constituents cannot be requested; however, when the analytical services request (ASR) form is filled out prior to sample mailing, a comment can be added to the form requesting that NWQL save the organic extracts for 6 months in case reanalyses are neccesary.

Historical data for numerous sites in New Jersey leads one to expect to see high values for zinc and chromium in streambed material associated with high values for iron and manganese. Mercury is frequently present in small but detectable amounts in streambed material in New Jersey streams. With the NWQL reporting limit for mercury at $0.01 \mu \mathrm{g} / \mathrm{g}$ (PC 71921, as of 2002), values up to $0.05 \mu \mathrm{g} / \mathrm{g}$ are allowed without submitting a laboratory rerun request. If a reported value for mercury is greater than $0.10 \mu \mathrm{g} / \mathrm{g}$, ask for a reanalysis and consult with the District WaterQuality Specialist. If values for lead in streambed material are greater than the minimum laboratory reporting level, consult the District Water-Quality 
Carbon values in streambed materials should be checked to be sure that the total carbon (PC 00693) is greater than the inorganic carbon alone (PC 00686). This can be done by looking at a table retrieval of the carbon data.

Ammonia nitrogen values are checked to be sure the Kjeldahl nitrogen value (PC 00626) is greater than the ammonia nitrogen value alone (PC 00611). Do not be concerned if the KJD nitrogen value is two or three orders of magnitude larger than the ammonia nitrogen value. This simply indicates that the organic nitrogen in the sediments has not yet been degraded to the ammonia form. A high ratio of organic to ammonia nitrogen in the sediments would be supported by a similarly high ratio of organic carbon to inorganic carbon because high values for KJD nitrogen in sediments are common downstream from wastewatertreatment plants. If analysis of streambed material results in a KJD nitrogen concentration greater than $100 \mathrm{mg} / \mathrm{g}$ and no wastewater-treatment plant is present within one-half mile upstream from the sampling site, a reanalysis should be requested.

Phosphorus (PC 00668) also can be high in streambed materials. Historical data for New Jersey indicate that concentrations of $\mathrm{P}$ greater than $500 \mathrm{mg} / \mathrm{kg}$ could be the result of effluent from a wastewater-treatment plant or high concentrations of iron. Check to see whether a wastewater-treatment plant is present within about one-half mile upstream from the sampling site; if so, the value is acceptable because high $\mathrm{P}$ values are common in streambed materials downstream from such plants. Iron sorbs with compounds containing $\mathrm{P}$ in the sediments. As a result, both $\mathrm{P}$ and iron concentrations can be high in the streambed materials regardless of whether or not the site is downstream from a wastewatertreatment plant. If both $\mathrm{P}$ and iron concentrations are high in the streambed material, expect the concentration of $\mathrm{P}$ in the water column to be low because $\mathrm{P}$ is bound up in the sediments. An exception to this would be total $\mathrm{P}$ in a water sample collected during high flows when the streambed material is resuspended. In summary, if a concentration of $P$ greater than $500 \mathrm{mg} / \mathrm{kg}$ in the sediments cannot be explained by association with high concentrations of iron in streambed material or by the proximity of a wastewater-treatment plant, then a laboratory reanalysis should be requested for the phosphorus.

In water year 1999, the USGS/NJDEP Ambient Stream Monitoring Network (ASMN) program started analyzing for polyaromatic hydrocarbons (PAH's) in streambed-material samples. NWQL analyzes for a group of PAH's that are requested by using the add-on custom laboratory code (not schedule) 9502 on the ASR forms. PAH's are indicators of urban land use and should be expected in streams below urban areas. Because a historical record does not exist in New Jersey, no method has been established to review the values and request reanalysis. The first three PAH constituents that appear on a WATLIST table of PAH results received from NWQL are not analyzed constituents; they are surrogate recoveries. The parameter codes are PC 49278 through PC 49280. Surrogates are compounds added to the sample for quality control. The surrogate values are reported in terms of percent recoveries and ideally should be 100 percent. If all three surrogates have values greater than 60 percent, this is an indication that the values are reliable. 


\section{OLD VALUES IN THE STATISTICAL LIBRARY}

Some sites were sampled many years ago (for example, in the 1970's), were discontinued as sampling sites, and then recently (1990's) put back into the sampling network. These sites, therefore, have libraries of constituents with concentration values that may not reflect current stream conditions. The outliers in the QWOUTLIERS program output are based on an analysis of the old values, which may no longer be representative. Old values may not be applicable because (1) streams in general now have fewer contaminants because of more stringent requirements on sources discharging to streams, (2) sampling techniques have improved, and (3) analytical methods and detection levels have changed. The data from sites with a long break in the period of record can be allowed a greater variability when outliers show up in the program output.

\section{LOW HIGH-END OUTLIERS}

Although the title of this section might seem contradictory, water samples from many stream sites in New Jersey have low ionic strength, and certain constituents historically are present at only 100ths of a milligram per liter, for example nutrients in water from New Jersey Pine Barrens sites. When high-end outliers are in the 100ths of a milligram per liter range, asking for reruns of analyses is not necessary. Keep in mind laboratory precision and detection limits. A value of $0.05 \mathrm{mg} / \mathrm{L}$ really is not much greater than a value of $0.04 \mathrm{mg} / \mathrm{L}$. 


\section{Specific Constituents as Outliers}

\section{GAGE HEIGHT (PC 00065)}

When gage height (which represents stream stage) is shown as an outlier, first verify the entry in the database. Values sometimes get entered incorrectly. Also, the reference point (RP) reading is often mistakenly entered as the gage-height reading.

After checking for data-entry errors, outliers for gage-height readings should still be viewed with caution. Every time a staff gage is changed or when a new bridge is built at a site, the new staff gage that is installed has a new datum. When there is a high- or low-end outlier for gage height, check to see whether a new staff gage has been installed recently. In contrast, when the reviewer looks at the statistics to see whether a particular gage height reading is high or low in order to make a judgment about whether or not some other outlier is acceptable, the reviewer ideally should keep in mind that the statistics could be an average of readings from several different staff gages that were installed at the site at different periods in the measurement history of the site. For example, the statistics sheet could indicate that a current gage height reading is near the median value when, in fact, the stream had a very low or high flow for that sample. This is an important point because interpretation of outliers depends heavily on whether flow was high or low.

\section{DISSOLVED SOLIDS SUM OF CONSTITUENTS (PC 70301)}

Dissolved solids sum, SUM, or sum of constituents, is a calculation. It is not a measured constituent. It includes, among other constituents, the concentrations of major ions, silica ( $\mathrm{SiO} 2)$ and laboratory ANC (acid-neutralizing capacity, previously called alkalinity) converted to $\mathrm{HCO} 3$. For a list of which constituents are required, which are included if present, and how the calculation for SUM is made, consult the NWIS user's manual (U.S. Geological Survey, 2001, app. D). SUM and other calculated values that the reviewer will see on the WATLIST table are defined. The constituents required for SUM are a field or laboratory value for one of ANC, alkalinity, bicarbonate, or carbonate, and concentration values for all of the constituents $\mathrm{Ca}, \mathrm{Mg}, \mathrm{Na}, \mathrm{Cl}$, $\mathrm{SO} 4$, and $\mathrm{K}$. Optional constituents include fluoride (F), $\mathrm{SiO} 2$, nutrients, and trace elements.

For SUM of constituents, nutrients may not have been included in old sample analyses (before 1977); the effect of their absence may be larger than anticipated because of conversion factors. For example, $\mathrm{NO} 2+\mathrm{NO} 3$ as $\mathrm{N}$ is multiplied by 4 to get the amount included in the SUM of constituents. The same type of situation occurs with PO4, where PO4 as $\mathrm{P}$ is multiplied by 5.27. For nutrient loads in surface waters, NO3 as N is typically the biggest contributor to sum of constituents.

Consider a long-term site for which dissolved nutrients were recently added to the sampling routine. The SUM of constituents in the older samples in the statistical library was calculated without nutrients. New analyses will include nutrients in the calculations. Therefore, SUM for the new analyses will include nutrients and will be compared in the statistical analysis to SUMs of past analyses which do not include nutrients. This may cause the more recent value of SUM to be a high-end outlier.

For other notes about SUM, see subheadings SUM/LSC and ROE/SUM in the section "QWREVIEW Printout".

\section{DISSOLVED RESIDUE ON EVAPORATION AT 180 DEGREES CELSIUS (PC 70300)}

The analysis of dissolved solids residue on evaporation at $180{ }^{\circ} \mathrm{C}(\mathrm{ROE})$, sometimes referred to as total dissolved solids, is done in part for quality-assurance purposes. It is not precise. The determination is made by evaporation and drying at $180{ }^{\circ} \mathrm{C}$ of a measured sample in a weighed container (Fishman and Friedman, 1989, p 437). A drinking-water secondary maximum contaminant level and instream water-quality standard exist for total dissolved solids (TDS), which is called ROE in this report (New Jersey Department of 
Environmental Protection, April 1998; Shelton, 1996).

Small infractions that involve ROE can be allowed because of the relatively poor precision of this measurement, but groups of infractions will serve as an alert to the reviewer. Questionable values from several sites analyzed the same day might indicate temporary systematic bias in the laboratory analysis.

In general, if the ROE value has a warning on the QWOUTLIERS report, but there are no other problems with SUM or ion balance, the ROE is not reanalyzed. If both ROE and SUM have outlier warnings and confirm each other, ROE is not reanalyzed. In other words, requests to the laboratory to rerun ROE are rarely made unless the reanalysis can provide additional information. There are exceptions: consider a rerun if ROE/ SUM is greater than 2.0 at a site with low-ionicstrength water or above 1.5 at a site with high specific conductance. See the notes above about ROE/SUM in the section "QWREVIEW Printout."

Another general rule is that if the SC is less than $70 \mu \mathrm{S} / \mathrm{cm}$, reanalysis of a high ROE value that is high-end outlier is not necessary. An exception to this rule occurs when the ratio ROE/ SUM is extremely high (more than 2.0).

ROE could be a high-end outlier as a result of large concentrations of dissolved organic compounds in the water. Although ROE is analyzed using filtered water, DOC will pass through the filter and contribute to ROE. This is a common occurrence in water from streams in the New Jersey Pine Barrens.

\section{MAJOR IONS, SILICA, AND ALKALINITY OR ACID- NEUTRALIZING CAPACITY}

The major ions are calcium $(\mathrm{Ca})$, magnesium $(\mathrm{Mg})$, sodium $(\mathrm{Na})$, potassium $(\mathrm{K})$, chloride $(\mathrm{Cl})$, sulfate (SO4), and fluoride $(\mathrm{F})$. Silica ( $\mathrm{SiO} 2)$ and field alkalinity or laboratory ANC are included in this discussion of major ions. Field alkalinity (or laboratory ANC) can be extremely low in waters with low $\mathrm{pH}$.
Concentrations of major ions are rarely present in samples at less than their laboratory reporting level (LRL) or their minimum reporting level (MRL). If the number of previous samplings is high, the reviewer probably should ask for reanalyses on high-end outliers of major ions. Even $\mathrm{K}$, which is usually a small percentage of the ion balance and may not be great enough to be part of the ion balance, should nonetheless be present at greater than the LRL or MRL, except in samples from sites with water of extremely low ionic strength. Investigate further when any common ions are less than the MRL. Fluoride is an exception, and in New Jersey is frequently present at concentrations less than the MRL in water year 2002 of $0.11 \mathrm{mg} / \mathrm{L}$.

Calcium (PC 00915).-- If the $\mathrm{Ca}$ concentration is a high-end outlier, look for high values for anions such as alkalinity (or ANC) to balance the $\mathrm{Ca}$. If $\mathrm{Ca}$ concentration is high in winter, determine whether $\mathrm{Cl}$ is also high; calcium chloride is sometimes used for road deicing.

Ca concentrations vary in a somewhat predictable manner with stream discharge; as discharge increases, dissolved Ca usually decreases. A graph showing a logarithmic regression plot of discharge as a function of dissolved Ca can be helpful for the review of problems involving $\mathrm{Ca}$. The relation between $\mathrm{Ca}$ and discharge does not seem to hold true for sampling sites in the Pine Barrens of New Jersey because $\mathrm{Ca}$ values are low (typically less than $5 \mathrm{mg} / \mathrm{L}$ and sometimes less than $1 \mathrm{mg} / \mathrm{L}$ ). Regression analysis is explained below in the section titled "REGRESSION ANALYSIS."

Magnesium (PC 00925).-- If the Mg concentration is high in winter or early spring, determine whether $\mathrm{Cl}$ is high also. Magnesium chloride is sometimes used as a road deicing agent.

Sodium (PC 00930).-- Concentrations of $\mathrm{Na}$ can be elevated at low flows, especially at locations downstream from wastewater-treatment plants. Because sodium chloride is used widely for road deicing, concentrations of $\mathrm{Na}$ and $\mathrm{Cl}$ can be high in streams after a snowfall or when ice and 
snow are melting.

Potassium (PC 00935).-- According to Berner and Berner (1987, p. 209-210), nearly all (about 90 percent) $\mathrm{K}$ in streamwater comes originally from the weathering of silicate minerals, particularly potassium feldspar; about 7 percent comes from contamination. The average $\mathrm{K}$ concentration in major streams worldwide is 1.3 $\mathrm{mg} / \mathrm{L}$, and the range is 0.5 to $4.0 \mathrm{mg} / \mathrm{L}$. Potassium is a primary plant nutrient and is concentrated in leaves of trees. When trees lose their leaves in the fall, the concentration of $\mathrm{K}$ rises in streamwater as the $\mathrm{K}$ is leached out of leaf litter. Recent brush fires increase $\mathrm{K}$ in streamwater because wood ash contains high concentrations of $\mathrm{K}$. Unlike most other elements, $\mathrm{K}$ concentrations tend to increase during increased discharge because of dissolution of soluble salts from trees, leaf litter, and the soil.

The behavior of $\mathrm{K}$ is similar to that of nutrients such as $\mathrm{P}, \mathrm{NO} 2$, and NO3. Some high values can occur during low-flow periods.

If $\mathrm{K}$ is high in winter or early spring, determine whether $\mathrm{Cl}$ is also high. Potassium chloride is sometimes used as a road deicing agent.

At sites with water of extremely low ionic strength, K may be extremely low, even below the MRL in water year 2002 of $0.11 \mathrm{mg} / \mathrm{L}$. The small amount of $\mathrm{K}$ in the environment is taken up by plants and is not released into the water, except after forest or brush fires. Also see the comments above about potassium in the NA.K.WARNING test in the "QWREVIEW Printout" section.

Chloride (PC 00940).-- Road deicing is the main cause for high-end outliers of chloride. In the winter, after a snowstorm, rain, or a thaw, expect an increase in sodium chloride when runoff from the roads reaches the streams. Of course, this should not occur later than April or May in New Jersey unless there is a spring snow storm.

At sites with low-ionic-strength water, $\mathrm{Cl}$ can be slightly higher than median historical values at low flows. A slight increase in $\mathrm{Cl}$ concentration due to evaporation of streamwater at low flows could be enough to cause an outlier or new maximum when values are small.

Sulfate (PC 00945).-- The concentration of $\mathrm{SO} 4$ can be high during times of low flow. When the SO4 concentration is high, look for low gage height (low flow) and high SC. If these conditions are present and the ion-balance percent difference is low, then the SO4 concentration is correct.

If the $\mathrm{SO} 4$ concentration is low, check the $\mathrm{SC}$ value; low $\mathrm{SO} 4$ can be correlated with low SC. In the Pine Barrens Region of New Jersey, where streams are fed by ground water, the concentration of SO4 often correlates well with the concentration of DO when flows are low. When $\mathrm{SO} 4$ is a low-end outlier and the flow is low at a New Jersey Pine Barrens site, a regression analysis of $\mathrm{SO} 4$ as a function of DO is done to determine whether the $\mathrm{SO} 4$ value is reasonable. Under low DO conditions, $\mathrm{SO} 4$ is converted to sulfide. Regression analysis is explained in the section "REGRESSION ANALYSIS." Specify the log plot when the program asks for a choice of log or non-log.

Fluoride (PC 00950).-- The normal range for $F$ in streams in New Jersey is 0.1 to $0.2 \mathrm{mg} / \mathrm{L}$. It is often less than the MRL in water year 2002 of $0.11 \mathrm{mg} / \mathrm{L}$. A laboratory rerun is not requested for fluoride from stream sites unless the concentration is $0.3 \mathrm{mg} / \mathrm{L}$ or greater. The ALERT limit for the QWREVIEW program for $\mathrm{F}$ is set at the NJDEP MCL of $4.0 \mathrm{mg} / \mathrm{L}$.

Dissolved fluoride at sampling sites on the Millstone River in New Jersey occasionally has been found to be as high as 0.3 to $0.5 \mathrm{mg} / \mathrm{L}$. This usually occurs during summer from June to September.

Silica (PC 00955).-- Dissolved $\mathrm{SiO} 2$ is not sensitive to changes in streamflow. It is sensitive to changes in $\mathrm{pH}$, however, which in turn are sensitive to time of day and streamflow. Generally, the higher the $\mathrm{pH}$, the higher the $\mathrm{SiO}$. Also, $\mathrm{SiO} 2$ becomes more soluble as water temperature rises.

Silica is taken up by diatoms (algae), which 
use it in their shells and skeletons. Therefore, during algal blooms, $\mathrm{SiO} 2$ is likely to be low, especially in the near-surface layers of lakes and reservoirs.

Field alkalinity (PC 39086) and laboratory acid-neutralizing capacity (PC 90410).-- Filtered water is used for alkalinity analysis, whereas unfiltered water is used for the analysis of ANC (acid-neutralizing capacity). The water used in the laboratory determination by NWQL is unfiltered; therefore, the constituent is called ANC. This also was called alkalinity, but about April 1998 it was renamed ANC. In summary, the field value determined using filtered water is alkalinity, code 39086; the laboratory value determined using unfiltered water is ANC, code 90410 .

In contrast to most other constituents, the NWQL charges for reanalyses of ANC. Before asking for a reanalysis, compare laboratory ANC with field alkalinity and laboratory $\mathrm{pH}$, if they are available.

If laboratory ANC is an outlier, check the cation/anion balance at the bottom of the analysis on the WATLIST table. If the ion-balance percent difference is acceptable, the laboratory ANC probably is correct. If the percent difference is unacceptable or too high, the laboratory ANC could be incorrect and should be rerun.

As a general rule, when stream stage increases, ANC (or alkalinity) decreases. High water dilutes ANC (or alkalinity) as well as most other dissolved constituents and generally results in lower values for ANC (or alkalinity).

\section{PH (PC 00400) AND DisSOLVED OXYGEN (PC 00300)}

Algal activity in water tends to increase $\mathrm{pH}$ and DO during the daylight hours. Algal activity is most likely to occur on bright sunny days, during low flow, in broad expanses of water with little shade. DO concentrations greater than historical median values, field $\mathrm{pH}$ greater than 7.5 (which decreases considerably by the time of laboratory analysis), supersaturated DO, and POC concentrations greater than historical median values can all be related to field observations of abundant algae.

DO in surface water has a diurnal cycle related directly to the hours of daylight. At night, DO is usually below saturation levels. During the full daylight hours, water may become supersaturated with DO (greater than 100 percent of saturation). Conditions that affect DO levels in streams are (1) stream discharge, (2) temperature, (3) channel characteristics and how they affect reaeration, (4) loading of nutrients and organic material, and (5) algal activity.

DO in ground water is subject to different conditions than DO in surface water. Generally, DO is lower in ground water than in surface water; photosynthesis cannot occur underground, so no oxygen is produced. Any oxygen that is present is gradually used up by bacteria. As ground water moves downgradient and gets farther from the source of recharge, the oxygen level gets lower and approaches zero. In the upper reaches of stream basins, the concentrations of DO in stream water may be low between rain events because the stream water is primarily ground-water discharge.

\section{Percent dissolved oxygen, PERCENT SATURATION (PC 00301)}

Percent saturation DO is a calculated value, not a measured constituent. When this value is an outlier, check the data entry for the input constituents (water temperature, DO, barometric pressure, and SC). Compare the WATLIST table against the entries on the field form of field measurements and descriptions of ambient site conditions. If the values for field measurements were entered correctly, not much can be done. Although water can be supersaturated with oxygen, an exceptionally high value, such as 167 percent saturation DO, might indicate an incorrect meter reading or a faulty meter, and the reviewer should consider deleting the field value for DO or setting the DQI to Q in the database. Alternatively, when large amounts of algae photosynthesize and emit a lot of oxygen, percent DO can rise to 140 
percent on a regular basis and can even reach 180 percent. This is especially true at sites which are eutrophic.

\section{BAROMETRIC PRESSURE (PC 00025)}

Average barometric pressure at sea level is about $762 \mathrm{~mm}$ (millimeters) Hg. Following is a list of pressures in terms of millimeters of $\mathrm{Hg}$ and weather conditions associated with these pressures.

$735 \mathrm{~mm}$ - a powerful hurricane

$740 \mathrm{~mm}$ - a low pressure system such as a weak hurricane

775 to $780 \mathrm{~mm}$ - a high that would occur in the winter when it is cold and clear

A pressure of $809 \mathrm{~mm}$ was recorded in Northway, Alaska, on January 31, 1989, and was the highest recorded pressure for North America.

Pressure decreases as altitude above sea level increases. Pressure decreases $2.54 \mathrm{~mm} \mathrm{Hg}$ for each 100-ft rise in altitude. The highest altitude in New Jersey is approximately $1,800 \mathrm{ft}$, in High Point State Park in Sussex County.

\section{NITROGEN SPECIES}

According to Berner and Berner (1987, p. 229), three types of nitrogen $(\mathrm{N})$ are found in streams: (1) dissolved inorganic nitrogen, which includes NH4, NO2 and NO3; (2) organic nitrogen, which includes dissolved and particulate organic $\mathrm{N}$ from soil organic matter that has not been completely broken down; and (3) $\mathrm{N}$ in old minerals directly eroded from land. The first two types, but not the third, are considered for samples collected by the USGS/NJDEP Ambient-StreamMonitoring Network program.

In most surface waters, nitrate is present in greater amounts than is ammonia, and nitrite is present in much smaller amounts than either. Urban wastes tend to contain high concentrations of ammonia, whereas runoff from agricultural areas contains high concentrations of nitrate (Berner and Berner, 1987, p. 231). In streams, sources of $\mathrm{N}$ that result from human activity include (1) point sources, such as municipal and industrial waste water, septic tanks, landfills, animal feedlots; (2) diffuse or nonpoint sources, such as urban or rural runoff; and (3) acid precipitation that falls directly into lakes and streams. One nonpoint source is nitrate leached naturally from soil, a process accelerated by deforestation and cultivation. Nitrogen is present in runoff from agricultural land, from the application of nitrogen fertilizers, from animal wastes, and from cultivation of nitrogen-fixing plants.

In southern New Jersey, where soils are nutrient-poor, large amounts of ammonia-based fertilizer are used for agriculture. This fertilizer is oxidized rapidly to NO3 in a process called nitrification, which occurs in the unsaturated zone and in ground water. The ground water below agricultural land discharges into nearby streams.

Outliers for all nutrients, including the nitrogen species, are analyzed by the COMP.PPL program on a seasonal basis. In warm water (greater than $10^{\circ} \mathrm{C}$ ), bacteria break down ammonia to $\mathrm{NO} 2$ and $\mathrm{NO} 3$. As a result, in warmer water, concentrations of ammonia will be lower and $\mathrm{NO} 2$ and NO3 will be higher. In cold water, ammonia will be higher and $\mathrm{NO} 2$ and $\mathrm{NO} 3$ will be lower. Ammonia concentrations can be high during the cold season downstream from a wastewater-treatment plant.

Nitrite (PC 00613) and nitrate as nitrogen.-- NO2 and NO3 are always dissolved; neither NO2 or NO3 is suspended. Thus, dissolved NO2 plus NO3 equals total NO2 plus NO3, dissolved NO2 equals total NO2, and dissolved NO3 equals total NO3. When water samples are analyzed for both total and dissolved nitrite or nitrate, the resulting values should be close. This can be a good check for a questionable value. If few values for either dissolved $\mathrm{NO} 2$ or $\mathrm{NO} 3$ are stored in the database for the site being reviewed, the values for total $\mathrm{NO} 2$ and $\mathrm{NO} 3$ can be used to obtain a data distribution because the total and 
dissolved values for $\mathrm{NO} 2$ and $\mathrm{NO} 3$ should be the same.

In nearly all natural well-oxygenated water, concentrations of NO2 typically are much lower than concentrations of NO3. Concentrations of NO2 are usually much less than 5 or 6 percent of concentrations of NO3. Where algae or a lot of waterfowl are present, the concentration of $\mathrm{NO} 2$ can be much greater than 5 or 6 percent of the concentration of NO3.

Concentrations of $\mathrm{NO} 2$ and $\mathrm{NO} 3$ can be affected by the concentration of DO. If the DO concentration is extremely low, for example less than $1.5 \mathrm{mg} / \mathrm{L}$, then dissolved NO2 plus NO3 should be small to negligible.

Concentrations of $\mathrm{NO} 2$ and $\mathrm{NO} 3$ in surface waters can be high during low flow. Less water is available to dilute them, and they become concentrated.

NO3 is commonly high downstream from wastewater-treatment plants. NO3 is a by-product of the treatment process used to oxidize and remove ammonia from wastewater. The NJDEP MCL for NO3 (and for combined NO2 and NO3) is $10 \mathrm{mg} / \mathrm{L}$.

Ammonia as nitrogen (PC 00608 and 00610).-- NH4 is similar to NO2 and NO3 in that dissolved and total values should be about the same. If either total or dissolved ammonia is a high-end outlier, compare the two values to see whether both are high, and compare NH4 with KJD nitrogen (NH4 + organic nitrogen) to see whether they are also high. KJD nitrogen should be higher than $\mathrm{NH} 4$ alone. If these values tend to confirm one another, then they probably are acceptable.

If the sampling site is downstream from a nearby wastewater-treatment plant, ammonia may be higher in the cold season. For more information about the seasonal nature of ammonia and its relation to NO3, see the general comments above in "Nitrogen species."

Kjeldahl nitrogen (PC 00623 and 00625).-
This species goes by several names-- Kjeldahl nitrogen, KJD, or TKN--and is the sum of ammonia as nitrogen and organic nitrogen. KJD behaves differently from $\mathrm{NO} 2, \mathrm{NO} 3$, and $\mathrm{NH} 4$ in that the dissolved values are usually different from the total values. As a general rule, in New Jersey waters, the dissolved value is typically one-half or more of the total value; however, if algal activity is abundant, the total value can be much greater than the dissolved value, for example, $0.15 \mathrm{mg} / \mathrm{L}$ for dissolved KJD and $2 \mathrm{mg} / \mathrm{L}$ for total KJD.

A general correlation exists among total $\mathrm{KJD}$, discharge, and total suspended residue at $105^{\circ} \mathrm{C}$. At high streamflows, high values of total KJD and total suspended sediment can be expected. Dissolved KJD commonly is greater than historical median values during high flow, in contrast to the general rule that dissolved constituents decrease with increased discharge because of dilution.

Of particular note is the effect of urea fertilizer, which is high in organic nitrogen, and is sometimes used in place of sodium chloride $(\mathrm{NaCl})$ as a road de-icer when there is a shortage of road salt. If KJD values are elevated during winter months and other nutrients are not, this could be an indication of the use of urea fertilizer as a de-icer.

\section{Phosphorus (PC 00665 AND 00666).}

The ultimate source of phosphorus $(\mathrm{P})$ is rock where it is present in the relatively insoluble mineral apatite. When $\mathrm{P}$ is released by weathering as the soluble phosphate (PO4) ion, most PO4 is bound quickly to soil particles as iron, aluminum, and calcium phosphates or to clay minerals in forms not accessible to plants (Berner and Berner, 1987, p. 232). The $\mathrm{P}$ that is available is readily taken up by biological systems, where it is concentrated and strongly conserved. P released by organic decay is quickly converted into other organophosphorus compounds. Ordinarily as a result of all these processes, only small amounts of $\mathrm{P}$ remain to occur naturally in streams.

NWQL Technical Memorandum 99.05 (U.S. 
Geological Survey, 1999) summarizes the results of samples analyzed for dissolved $\mathrm{P}$ during the period January 1997 through February 1998. About 90 percent of the values were less than $0.2 \mathrm{mg} / \mathrm{L}$. Only 1 percent was more than $2 \mathrm{mg} / \mathrm{L}$, and only 2 values of about 11,000 values were more than $10 \mathrm{mg} / \mathrm{L}$.

Concentrations of $\mathrm{P}$ that occur naturally in streams are quite low, averaging only $0.02 \mathrm{mg} / \mathrm{L}$ (Mitsch and Gosselink, 1993, p. 144). Levels above this are usually the result of human activities that introduce detergents, sewage, industrial wastes, and agricultural forms of $\mathrm{P}$ (fertilizer, animal wastes, and erosion of soil resulting from cultivation) into streams directly from nonpoint sources. In New Jersey, most dissolved $\mathrm{P}$ results from municipal sewage, and most of the $\mathrm{P}$ suspended in particles results from algae when stream levels are low and from streambed sediments when high flows resuspend the bottom material.

If the concentration of $\mathrm{P}$ is an outlier, check total $\mathrm{P}$ against dissolved $\mathrm{P}$, and check the stream stage or discharge. The total and dissolved values should not differ greatly at normal flows. Total $\mathrm{P}$ and dissolved $\mathrm{P}$ can be very low (less than the P.10 statistical value at a site) at midrange flows, which can be high enough to disperse and dilute algal growth and to dilute $\mathrm{P}$ concentrations but not high enough to stir up streambed materials.

At extremely low streamflows, concentrations of dissolved $\mathrm{P}$ and $\mathrm{PO} 4$ are greater than historical median values and can be high-end outliers. If discharge and, therefore, concentrations of suspended sediment are high, then total $\mathrm{P}$ (which includes particulate, or suspended, P) can be much greater than dissolved $P$. Total $P$ values during high flows can exceed the upper limit and the maximum of record. Streambed sediments can contain a lot of total $\mathrm{P}$, so when high flow resuspends the streambed material, the total $\mathrm{P}$ on particulates is included in the sample. For example, if dissolved $\mathrm{P}$ is $0.03 \mathrm{mg} / \mathrm{L}$ and total $\mathrm{P}$ is $0.98 \mathrm{mg} / \mathrm{L}$ in a sample and the stream stage was high, these might be reasonable values. If the stream stage was low, however, the two $P$ values should not be that different. A rerun or verification of the outlying value should be requested and (or) deletion considered if the values differ greatly. Also, check the suspended sediment or solids concentration; if it is high, then the total $\mathrm{P}$ also is likely to be high. As a general rule, if total $\mathrm{P}$ is a high-end outlier and it cannot be explained by high gage height and corresponding constituents, such as high concentrations of total suspended residue (PC00530) and POC, then ask for a laboratory reanalysis or verification of the total $P$ value.

In New Jersey waters, the dissolved P value should be about the same or larger than the dissolved PO4 value. If a dissolved PO4 value is available, use the $\mathrm{P}$ and $\mathrm{PO} 4$ values as checks against each other.

In October 1998, NWQL raised the reporting level for $\mathrm{P}$ to $0.05 \mathrm{mg} / \mathrm{L}$. This created the situation in which a value for $\mathrm{P}$ reported as $">0.05 "$ is often a high-end outlier because $0.05 \mathrm{mg} / \mathrm{L}$ is higher than any previously reported value at many sites. Because of this change in the reporting level for $\mathrm{P}$, if $0.05 \mathrm{mg} / \mathrm{L}$ occurs as a high-end outlier, check the WATLIST table to see whether it is reported as less than $0.05 \mathrm{mg} / \mathrm{L}$. If so, it isn't a problem. More recently, starting October 1999 for the USGS/NJDEP Ambient-StreamMonitoring Network program, the New Jersey District began requesting a low-level analysis for $\mathrm{P}$; reporting levels then were $0.007 \mathrm{mg} / \mathrm{L}$ for dissolved phosphorus and $0.008 \mathrm{mg} / \mathrm{L}$ for total phosphorus. In October 2001, reporting levels for total and dissolved $\mathrm{P}$ were changed to $0.0037 \mathrm{mg} / \mathrm{L}$. The result of these changes is that now many low-end outliers have been appearing for phosphorus. This complex history of changing reporting levels must be kept in mind by anyone reviewing $\mathrm{P}$ values.

\section{ORTHOPHOSPHORUS (PC 00671)}

All PO4 dissolved in water is in the ionic form. Dissolved PO4 is a part of dissolved and total phosphorus and, therefore, should not be greater than either of them; however, it should have about the same value as dissolved P (and total $\mathrm{P}$ at normal flows). The acceptable range in New Jersey waters for dissolved PO4 is 92 to 103 


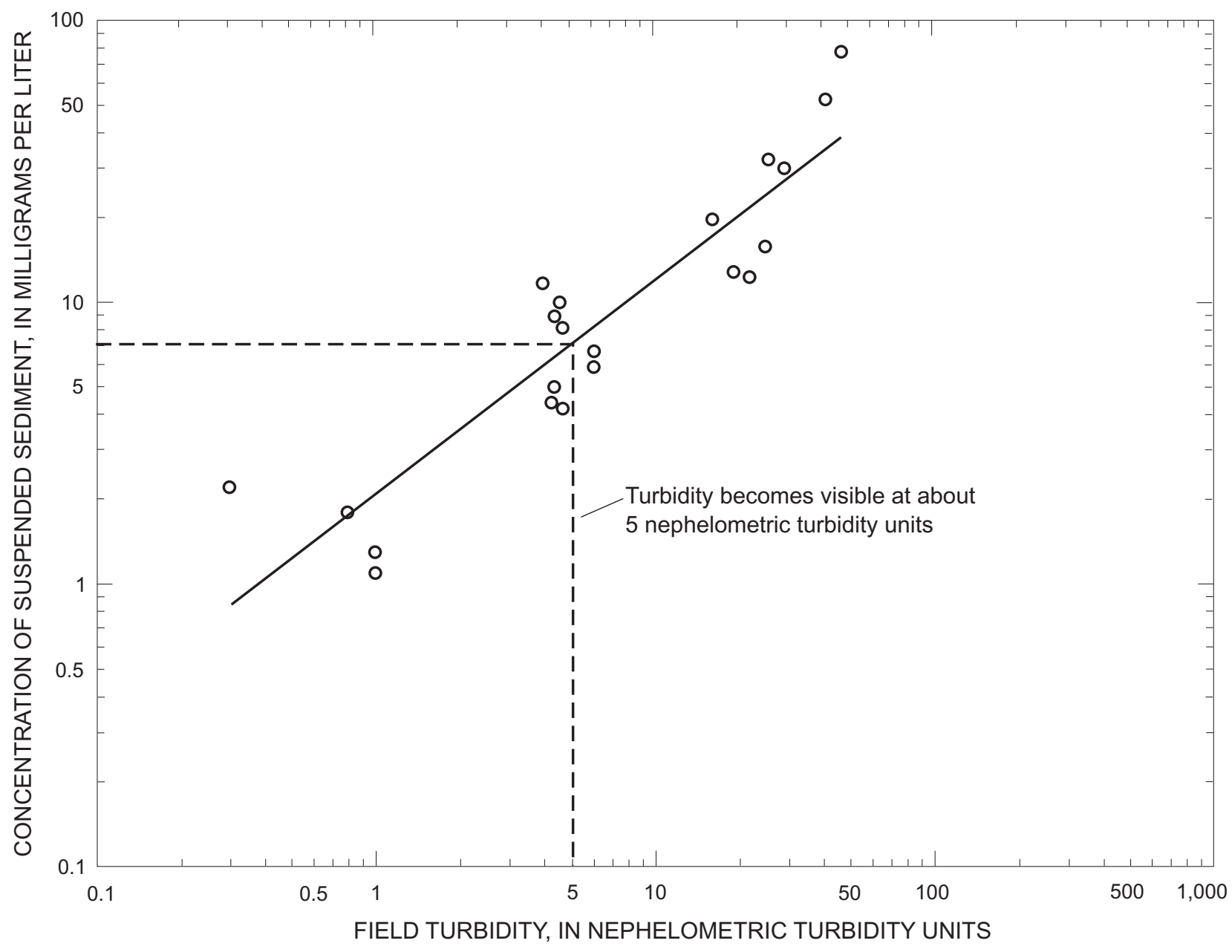

Figure 2. Regression plot of suspended sediment concentration in relation to field turbidity for the Delaware River at Trenton, N.J. 
percent of dissolved $\mathrm{P}$ (PC 00666). This relation can be used to check the two values when one or the other (or both) is an outlier. If PO4 is more than 103 percent of $\mathrm{P}$, a problem with the laboratory analysis is indicated. The reviewer can consider a reanalysis of one or both constituents. 
PO4 concentrations, as do most dissolved constituents, vary inversely with streamflow. High-end outliers are common for dissolved PO4 at very low streamflows.

\section{IRON (PC 01045 AND 01046)}

The concentration of iron in solution (dissolved $\mathrm{Fe}$ ) is heavily dependent on DO and $\mathrm{pH}$. For example, in anoxic waters, when the concentration of DO is less than $1.5 \mathrm{mg} / \mathrm{L}$, the concentration of Fe can be extremely large (greater than $1 \mathrm{mg} / \mathrm{L}$ ). On the other hand, water in a fully aerated flowing stream should not contain more than a few micrograms per liter of dissolved $\mathrm{Fe}$ at equilibrium in the $\mathrm{pH}$ range of 6.5 to 8.5 (Hem, 1992). If $\mathrm{pH}$ is 7 and DO is more than 5 $\mathrm{mg} / \mathrm{L}$, the theoretical solubility limit for dissolved $\mathrm{Fe}$ is 3 to $4 \mu \mathrm{g} / \mathrm{L}$. A practical high outlier concentration for $\mathrm{Fe}$ in filtered oxygenated water is approximately $700 \mu \mathrm{g} / \mathrm{L}$.

At New Jersey Pine Barrens sites, Fe can be slightly elevated above historical median values because it becomes concentrated at low flows. Only a small increase in Fe will result in an outlier or a new maximum when values are already small. Also, Fe at these New Jersey sites can be greater than historical median values after a rain because $\mathrm{Fe}$ is flushed into streams from peat bogs and swamps that contain water low in DO.

\section{BORON (PC 01022)}

Boron can be present in water as a result of human activity. In New Jersey, background values of boron in surface waters range from approximately 6 to $20 \mu \mathrm{g} / \mathrm{L}$. Effluent from wastewater-treatment plants contains about 250 to $1,000 \mu \mathrm{g} / \mathrm{L}$ boron (Leenhouts and others, 1998, p. 241). Boron as sodium perborate is used in laundry detergents and some other soaps as a whitening agent. Also, boron is present in fertilizer as a micronutrient (essential, but in small quantities applied at less than 1 pound per acre) for agricultural row crops (Cornell University, 2001). Thus, in agricultural areas, the concentration of boron in runoff could be high after a storm.

\section{TOTAL SUSPENDED RESIDUE (PC 00530) AND SUSPENDED SEDIMENT (PC 80154)}

Total suspended residue and suspended sediment are comparable constituents at low concentrations (less than $20 \mathrm{mg} / \mathrm{L}$ ) and low stream velocities (less than 1.5 to 2 feet per second $(\mathrm{ft} / \mathrm{S})$ ). At these conditions, sand particles are not suspended, and the two constituents should have comparable values. Both are measurements of suspended solids in water, both are measurements of the increase in filter weight divided by the volume of water filtered, and both are expressed in milligrams per liter. The difference is that for the suspended sediment analysis the whole sample bottle of water is filtered and for the total residue analysis a subsample (aliquot) of the sample water is filtered.

NWQL Technical Memorandum 00.03 dated March 8, 2000 (U.S. Geological Survey, 2000), states that effective April 1, 2000, the MRL for total suspended residue was raised from $1 \mathrm{mg} / \mathrm{L}$ to $10 \mathrm{mg} / \mathrm{L}$. At best, total residue (or suspended sediment) concentrations are accurate only to 1 or $2 \mathrm{mg} / \mathrm{L}$. Values of 2 and $5 \mathrm{mg} / \mathrm{L}$ are considered to be not significantly different.

Total residue (or suspended sediment) concentrations correlate positively with values of turbidity. Turbidity becomes visible in water at a value of about 5 NTU (nephelometric turbidity units) (Shelton, 1996, p. 31). This value of 5 NTU correlates with a total residue (or suspended sediment) concentration of 6 to $7 \mathrm{mg} / \mathrm{L}$ in New Jersey waters. At a field turbidity of 5 NTU, the laboratory value for suspended sediment concentration is about $7 \mathrm{mg} / \mathrm{L}$ for the Delaware River at Trenton, N.J.; this relation is shown in figure 2 .

High values for suspended solids should be checked against the field notes. If field notes show the stage was low and there was no recent precipitation, then a high value should be questioned. The high value was probably a result 


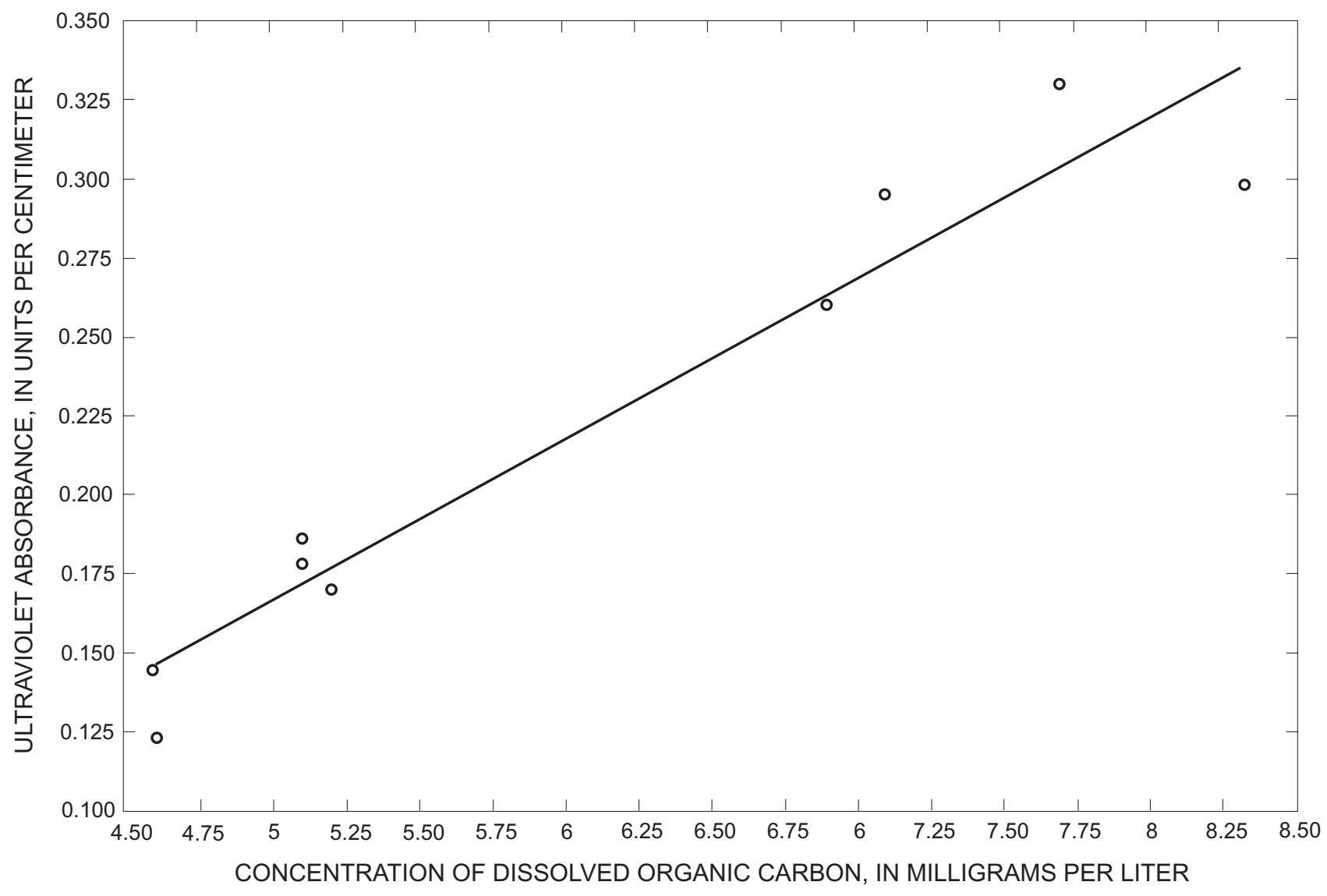

Figure 3. Regression plot of UV254 (ultraviolet-absorbing organic constituents, 254 nanometer wavelength) in relation to dissolved organic carbon for the Passaic River at Two Bridges, N.J. 
of the sampling device hitting the stream bottom and stirring sediments when the sample was collected.

High values for suspended solids correlate positively with higher than historical median values for POC, coliform bacteria (when available), and total KJD nitrogen. The suspended solids concentration should be greater than the POC concentration because it includes POC. If a high value for suspended solids is questionable, check the values for POC, coliform bacteria (if available) and total KJD nitrogen. A value of 80 $\mathrm{mg} / \mathrm{L}$, for example, is high but is quite possible. Suspended sediment concentrations as high as 230 $\mathrm{mg} / \mathrm{L}$ have been measured in New Jersey streams.

Sites in the New Jersey Pine Barrens tend to have low values for suspended solids even during storms. Prior to the raising of the reporting level from $1 \mathrm{mg} / \mathrm{L}$ to $10 \mathrm{mg} / \mathrm{L}$ by NWQL on April 1 , 2000, values of less than $1 \mathrm{mg} / \mathrm{L}$ were common, even during and after heavy rains. Stream velocities are too low to suspend fine-grained sediment, and fine-grained sediment is not abundant in this part of the Coastal Plain physiographic province in New Jersey.

\section{ORGANIC CARBON}

Total organic carbon (TOC) is the sum of dissolved organic carbon (DOC) and particulate organic carbon (POC). DOC is usually greater than POC. As flow increases, however, and the suspended load increases, POC increases relative to DOC. During high streamflows, the POC concentration can be as much as the DOC concentration. For example, a DOC concentration of $5 \mathrm{mg} / \mathrm{L}$ can occur with a POC concentration of $4 \mathrm{mg} / \mathrm{L}$.

\section{Dissolved organic carbon (PC 00681).--} According to Drever (1988, p. 37, 45), all natural waters contain dissolved organic compounds. Even rainwater has DOC concentrations of 0.5 $\mathrm{mg} / \mathrm{L}$ to $1.5 \mathrm{mg} / \mathrm{L}$. About half of the DOC in streams is in the form of humic and fulvic acids, and the rest is other organic compounds. The organic layer in soils is a major contributor of these soluble organic compounds found in streams. Thus DOC in streams comes, in large part, from precipitation percolating down through the organic material in the soil zone that becomes ground water, which then discharges into the streams. In lakes and slow moving streams, biological activity (primarily algae) in the water also can contribute to DOC.

Concentrations of DOC in streams typically range from $2 \mathrm{mg} / \mathrm{L}$ to $15 \mathrm{mg} / \mathrm{L}$ (excluding streams that drain swamps and wetlands) (Drever, 1988, p. 45). The average in New Jersey is 4 or $5 \mathrm{mg} / \mathrm{L}$. A concentration of $12 \mathrm{mg} / \mathrm{L}$ for DOC is high but reasonable after a heavy rain or when ground water is discharging into a stream. The concentration of DOC is often high in shallow ground water. Streams that drain swamps and wetlands have the highest DOC concentrations, ranging from $5 \mathrm{mg} / \mathrm{L}$ to $60 \mathrm{mg} / \mathrm{L}$ and averaging 25 mg/L (Drever, 1988, p.45). Concentrations as high as $47 \mathrm{mg} / \mathrm{L}$ of DOC have been measured in samples from streams in the Pine Barrens of New Jersey. Lakes usually have DOC concentrations of $1 \mathrm{mg} / \mathrm{L}$ to $3 \mathrm{mg} / \mathrm{L}$ unless they are downstream from or part of a swamp or bog.

When a note is made in field records that the water is a dark tea color, one can expect to see a high value for DOC. This is common at New Jersey Pine Barrens sites. Also, water with a high concentration of DOC foams when the sample is shaken; the foam looks like soap suds when seen in the stream.

At New Jersey Pine Barrens sites, concentrations of DOC can be quite high during and after rain. The more it rains, the more DOC is flushed out of the ground and peat bogs into the streams. A DOC concentration of $17 \mathrm{mg} / \mathrm{L}$ would not be unusually high during and after heavy rain. The high concentration of DOC can last as long as a couple of days after the end of a storm as water from precipitation travels through the ground and seeps into the stream.

Another source of carbon in stream water is vegetation which falls into the stream. In late fall when an abundance of leaves is found in streams, concentrations of DOC and POC can be greater 
than usual.

Beginning February 1998, the USGS/ NJDEP Ambient-Stream-Monitoring Network program personnel started collecting samples for UV254 analysis. UV254 analysis measures absorption by organic constituents in water of ultraviolet light of wavelength 254 nanometers. For a particular sampling site, the values typically have a close positive correlation with values of DOC. A regression plot of UV254 in relation to DOC is shown in figure 3. These plots are useful for determining the validity of unusually high or low values of DOC received from NWQL. Regression analysis is explained below in "REGRESSION ANALYSIS."

Ground-water samples typically contain fairly low concentrations of DOC, unless the well is a shallow one. A sample from an 8-ft-deep well next to a bog in the New Jersey Pine Barrens contained DOC at a concentration of $18 \mathrm{mg} / \mathrm{L}$.

\section{Particulate organic carbon (PC 00689).--} Particulate organic carbon (POC), which is suspended in the water, is often present at higher than median historical values at times of high streamflow. POC also can be high at times of low flow when an abundance of algae is present, especially in samples collected in or downstream from reservoirs where the water stagnates. The value of POC can be as high as 3 or $4 \mathrm{mg} / \mathrm{L}$ under these environmental conditions. When the value of POC is a high-end outlier, check the field notes for high flow or for mention of algae or green water.

In or downstream from a lake or reservoir, low concentrations of POC are typical because the water moves slowly through such a body of water and POC settles out. The exception to this, as noted above, occurs when algal activity is abundant, in which case concentrations of POC can be much higher than historical median values.

A high concentration of POC correlates positively with a high concentration of total suspended residue (PC 00530). The POC value cannot be greater than the total suspended residue value because POC constitutes only part of the suspended sediment. If POC is greater than the total suspended residue or total suspended sediment value, ask for a laboratory reanalysis or verification of the POC value, and consider asking the laboratory to reanalyze for total suspended residue.

A high concentration of POC also may correlate with a high concentration of total KJD nitrogen. If the POC value is high, look for a high total KJD value, or more accurately a high suspended KJD value. An interesting comparison can be made by making a table for the site in question that shows total KJD, dissolved KJD, gage height, and POC for the past several years. Suspended KJD, which is total KJD minus dissolved KJD, should vary in the same manner as the POC; high suspended KJD should correlate positively with high POC.

Total organic carbon (PC 00680).-- Total organic carbon (TOC) is the sum of DOC and POC. As the suspended load of a stream increases, POC becomes a greater part of TOC relative to DOC. TOC, chemical oxygen demand (COD), and biochemical oxygen demand (BOD) are different measurements used to evaluate the aggregate organic load in a stream.

\section{OXYGEN DEMAND}

Chemical oxygen demand (COD) and biochemical oxygen demand (BOD) are the results of two different methods used to estimate the amount of oxygen required to oxidize constituents in water or to evaluate the aggregate organic contaminant load in a quantitative way. TOC is the result of another method. Other similar measurements are sediment oxygen demand (SOD) and nitrogenous biochemical oxygen demand (NBOD). The USGS/NJDEP AmbientStream-Monitoring Network program typically does not deal with these last two.

\section{Chemical oxygen demand (PC 00340).--}

Chemical oxygen demand (COD) is used to measure the aggregate contaminant concentration of domestic and industrial wastes (Clesceri and others, 1998, p. 5-13). It is a measure of the readily oxidizable material in the water, oxidizable 
by chemical means in the laboratory. The determination can be made in about 3 hours, as opposed to 5 days for BOD determination. A strong oxidizing agent is added to the sample and heated. The amount of oxidizing agent used up is related to the COD.

Water samples from rivers that do not contain treated domestic wastewater generally have values for COD ranging from $10 \mathrm{mg} / \mathrm{L}$ to $30 \mathrm{mg} / \mathrm{L}$. Rivers that contain moderate amounts of treated domestic wastewater have values for COD ranging from $25 \mathrm{mg} / \mathrm{L}$ to $50 \mathrm{mg} / \mathrm{L}$, and domestic wastewater has values of about $250 \mathrm{mg} / \mathrm{L}$ for COD.

Water from bogs and swamps, such as those found in the New Jersey Pine Barrens, can have high COD values. This comes not from contamination but from the high DOC in the ground water that seeps out of the bogs and swamps, especially peat bogs. The DOC concentration can be high during, and for a couple of days after, a rain. The more it rains, the more DOC gets flushed out into the streams. Values of $30 \mathrm{mg} / \mathrm{L}$ to $40 \mathrm{mg} / \mathrm{L}$ for COD are not uncommon for New Jersey Pine Barrens water.

The samples analyzed for COD are not filtered. Thus, the sample for COD includes leaves, DOC, POC, oil, NH4, and organic N. In autumn, leaf particles contribute to high COD values. COD is proportional to TOC, or DOC plus POC, so that a sample with a high value for COD should have a high concentration of DOC plus POC.

Biochemical oxygen demand (PC 00310).This is a traditional measure of the effect of an organic waste load on the oxygen levels of a receiving body of water. In other words, it is a measure of contamination of a stream by sewage: the more sewage, the higher the BOD. As organic material (waste) is put into a stream, the microorganisms that are present degrade the material and consume oxygen in the process. This results in a decrease of the dissolved oxygen in the water. The standard BOD test measures the loss of oxygen within a certain measured volume of water in a 5-day period and is called BOD-5.

\section{FECAL COLIFORM (PC 31615) AND ENTEROCOCCI (PC 31649) BACTERIA}

Fecal coliform counts higher than historical median values usually correlate positively with high suspended sediment values (total suspended residue, PC 00530, or suspended sediment, PC 80154). Therefore, they also correlate positively with high stream discharge values. Fecal coliform counts may be high because of the presence of waterfowl. This is especially true during October and November when waterfowl are migrating, but with the increase of waterfowl that have taken up residence, this can occur anytime of the year. If fecal coliform concentrations in a sample are higher than historical median values, the field notes should be checked for mention of waterfowl.

Enterococci are a preferred water-quality indicator for recreational waters. It is better than fecal coliform bacteria as a predictor of swimming-associated gastroenteritis in marine and fresh water (Cabelli, 1977; Dufour and Cabelli, 1984). The freshwater criterion for enterococci is a geometric-mean concentration of 33 colonies per 100 milliliters (U.S. Environmental Protection Agency, 1986, p.15).

\section{VOLATILE ORGANIC COMPOUNDS (NWQL SCHEDULES 1307, 2020, AND 2021)}

The volatile organic compounds (VOCs) in NWQL Schedules 1307, 2020, and 2021 are determined for some New Jersey water-quality programs. Schedules are groupings of analytes. The COMP.PPL program does not test the VOCs in these schedules, except as outliers. For groundwater samples, if any constituent concentrations are greater than the reporting levels, ask the District Water-Quality Specialist whether the values are acceptable. Because these are not samples of drinking water, the constituent concentrations should not be compared to NJDEP or EPA drinking-water standards. During review of the results of analyses for VOCs in surface water, make a note of any values greater than the laboratory reporting levels. 
Chloroform, a trihalomethane, commonly is detected in small concentrations in both streamwater and ground water. Concentrations of 1 or $2 \mu \mathrm{g} / \mathrm{L}$ and less are not unusual.

Since its introduction in New Jersey as a gasoline additive, methyl tert-butyl ether (MTBE) is nearly always present in small amounts in streamwater, except in small pristine drainage basins. Concentrations typically are less than 0.2 $\mu \mathrm{g} / \mathrm{L}$ but occasionally can be as high as 1 or $2 \mu \mathrm{g} / \mathrm{L}$.

Parameter codes (PC), such as 99832, 99833 and 99834 , are used for quality-control measurements. An example is TOLUENE DB SURROG which is PC 99833. For these parameter codes the NWQL uses spikes, which are added to the sample for quality control. The values indicate percent recovery and ideally should be 100 percent. The laboratory accepts a range of 70 to 130 percent. If the value is outside this range, the analysis will be rerun automatically for VOCs. If the value is outside the range of 80 to 120 percent, consult the District Water-Quality Specialist to determine whether to request a rerun of the analysis.

\section{Pesticides (NWQL Schedules 1608 AND 2001)}

For the USGS/NJDEP Ambient-StreamMonitoring Network program, samples for NWQL Schedule 1608 and 2001 pesticides are currently (water year 2002) being collected at some stream sites. Samples for NWQL Schedule 2001 pesticides are collected at 30 ambient-groundwater-quality wells each year. The COMP.PPL program does not test the constituents in these schedules, except as outliers. If any pesticides are greater than the reporting levels, ask the District Water-Quality Specialist whether they are acceptable. Parameter codes that start with 91 are quality-control parameter codes. An example is DIAZINON SURROGATE which is parameter code 91063.

\section{RADIONUCLIDES}

Results of analyses for radioactive substances, such as radium, uranium, and gross alpha and beta, are not dealt with adequately by the COMP.PPL QWREVIEW program. This is due, in part, to the fact that the health standards for these have been changing. Questions should be directed to someone in the District who is working on projects involving radionuclides.

Different constituents are analyzed for in ground water than in surface water. Ground-water samples, when collected for the USGS/NJDEP Ambient-Ground-Water-Quality Network (AGWQN) program, are analyzed, in part, to determine whether the samples conform to USEPA drinking-water standards; this is a screening device to determine whether there might be a violation of the standards. For surface-water samples, radiochemical analytical results are not compared to drinking-water standards.

The following radiochemical constituents currently are tested (as of February 2002) by the COMP.PPL program to determine whether there are outliers:

PC 03515 Gross-beta radioactivity, dissolved, picocuries per liter ( $\mathrm{pCi} / \mathrm{L}$ ), as Cs-137;

PC 04126 Gross-alpha radioactivity, dissolved, $\mathrm{pCi} / \mathrm{L}$ as Th-230;

PC 09511 Radium-226, dissolved, Rn method;

PC 22703 Uranium, natural, water, dissolved;

PC 75990 Uranium, natural, water, dissolved, 2 sigma; and

PC 76001 Radium-226, water, dissolved, 2 sigma.

Entries on a WATLIST table that contain PE in the description (parameter codes 75985 through 76005) are the errors associated with particular determinations of radiochemicals. These errors, more appropriately called "2-sigma precision estimates" (PE), specify a possible range above and below the measured value to indicate how 
precise the value is. For each radiochemical constituent analyzed for, a PE determination is made. These are important to note because the measurement of radioactivity often can have a large associated error.

Surface-water samples.-- As of water year 2002, no surface-water samples collected for the USGS/NJDEP Ambient-Stream-Monitoring Network program are analyzed for radiochemistry. From time to time, surface-water samples are collected for projects with special needs and are analyzed for the constituents in NWQL Schedule 1703, which includes dissolved radium-226 (Ra226) and dissolved natural uranium (U). The parameter codes and constituents are

PC 09511 Radium 226, dissolved; PC 22703 Natural uranium, dissolved; and PC 75990 and PC 76001, which have PE in the description and are the 2-sigma precision estimates associated with the measured constituents.

The results for radium-226 and natural uranium are reviewed for outliers by the COMP.PPL program. Natural uranium values for the Delaware River at Trenton, N.J., for example, range from less than $0.04 \mu \mathrm{g} / \mathrm{L}$ to $0.17 \mu \mathrm{g} / \mathrm{L}$. For natural uranium, concentrations greater than $30 \mu \mathrm{g} / \mathrm{L}$ exceed drinking-water standards (U.S. Environmental Protection Agency, 2000, p. 76,710).

Ground-water samples.-- Samples for ambient-ground-water quality are collected for the USGS/NJDEP AGWQN program once a year at 30 sites. The constituents analyzed for radiochemistry are as follows:

PC 04126 Gross-alpha radioactivity, dissolved, $\mathrm{pCi} / \mathrm{L}$ as thorium-230

PC 03515 Gross-beta radioactivity, dissolved, $\mathrm{pCi} / \mathrm{L}$ as cesium-137

The following constituents were previously analyzed for but are no longer requested:

PC 80030 Gross-alpha radioactivity, dissolved, $\mu \mathrm{g} / \mathrm{L}$ as natural uranium

PC 80050 Gross-beta radioactivity, dissolved, $\mathrm{pCi} / \mathrm{L}$ as strontium-90

Parameter codes 75985 through 76005 , which have PE in the name, are the 2-sigma precision estimates associated with the above constituents.

Of the parameter codes listed immediately above, only PC 03515 and PC 04126 are reviewed by the COMP.PPL program. Because the COMP.PPL program is not designed at this time to do anything but flag outliers, the reviewer needs some other way to determine whether any value exceeds a USEPA drinking-water standard. The drinking-water standards for these are rather complicated and are detailed in the Federal Register (U.S. Environmental Protection Agency, 2000). Any questions should be directed to the District Water-Quality Specialist.

As a general rule of thumb, concentrations of gross alpha and beta should be less than $15 \mathrm{pCi} / \mathrm{L}$. If one of them is $15 \mathrm{pCi} / \mathrm{L}$ or greater, consult one of the radiochemistry project people or the District Water-Quality Specialist. Other constituents, such as radium (Ra) and uranium (U), have lower limits.

All ground-water analyses for the USGS/ NJDEP Ambient-Ground-Water-Quality Network are tested with the MCL program. MCL stands for maximum contaminant level. The MCL program is a program in P-STAT similar to the COMP.PPL program that is set up to alert the reviewer to any constituents that are greater than the drinkingwater standards of USEPA and NJDEP. The radionuclides tested by the program (as of March 2002) and their alert limits are as follows:

PC 03515 Gross beta, dissolved -alert limit $15 \mathrm{pCi} / \mathrm{L}$

PC 04126 Gross alpha, dissolved -alert limit $15 \mathrm{pCi} / \mathrm{L}$

PC 22703 Uranium, dissolved -alert limit $30 \mu \mathrm{g} / \mathrm{L}$ (or $30 \mathrm{pCi} / \mathrm{L}$ )

Alpha is a type of radioactivity emitted by 


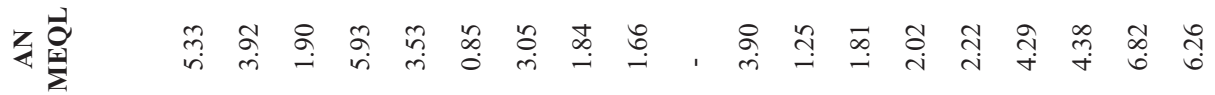

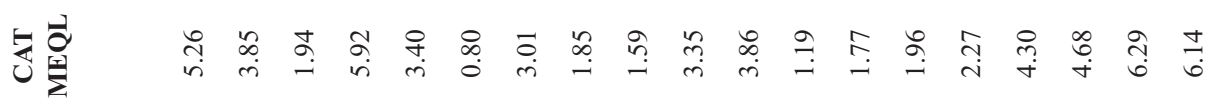

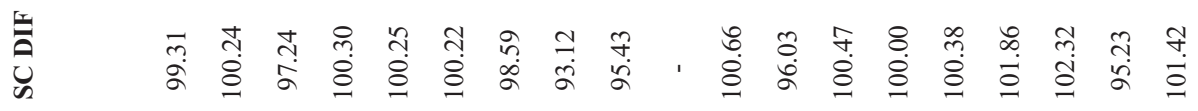

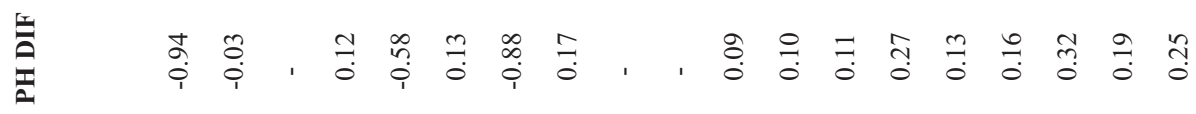

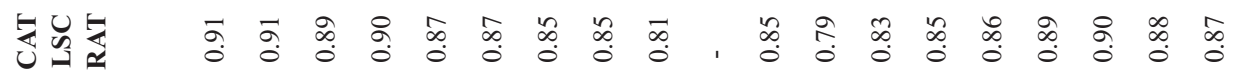

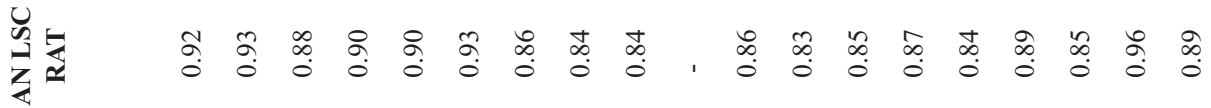

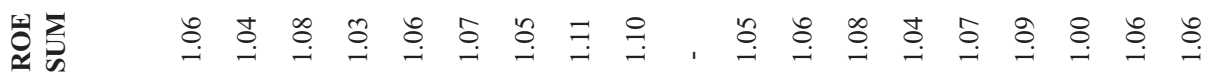

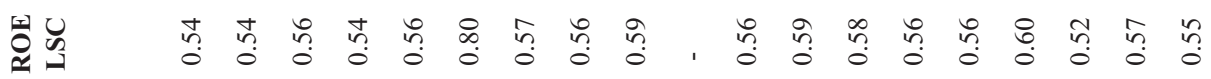

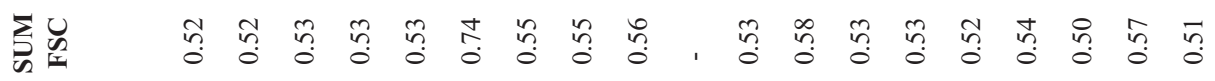

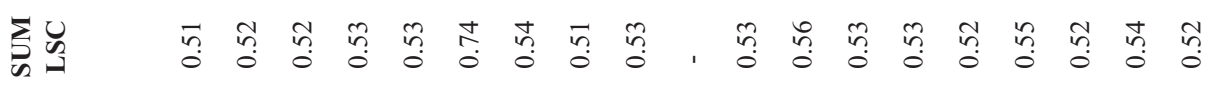

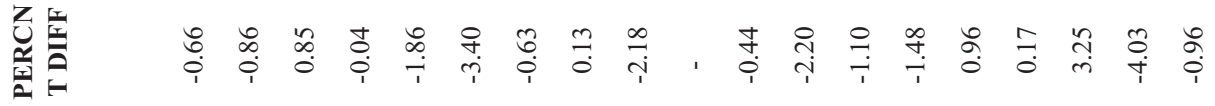

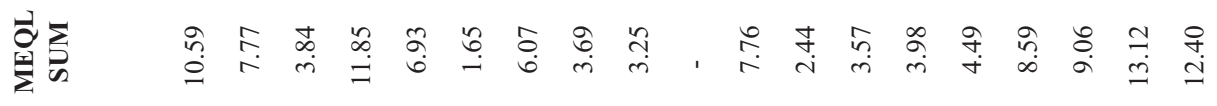

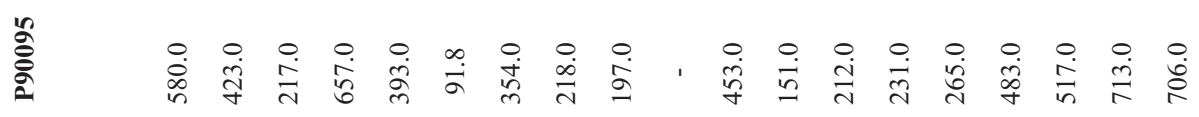

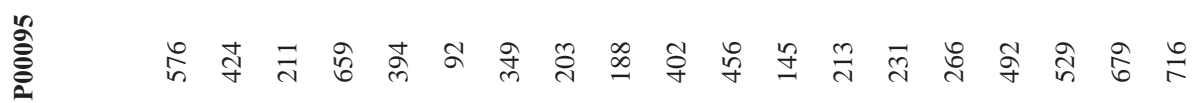

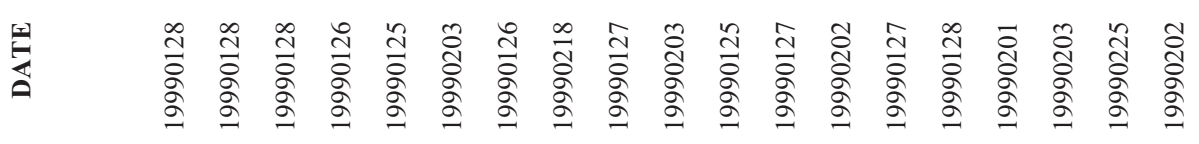

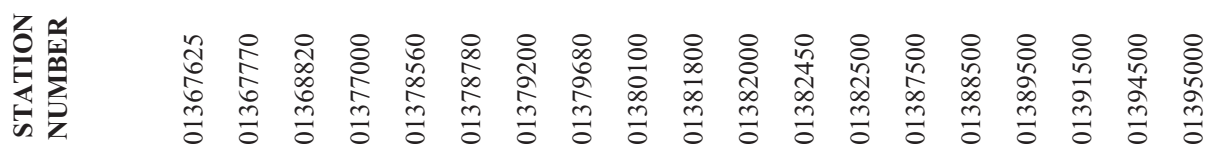




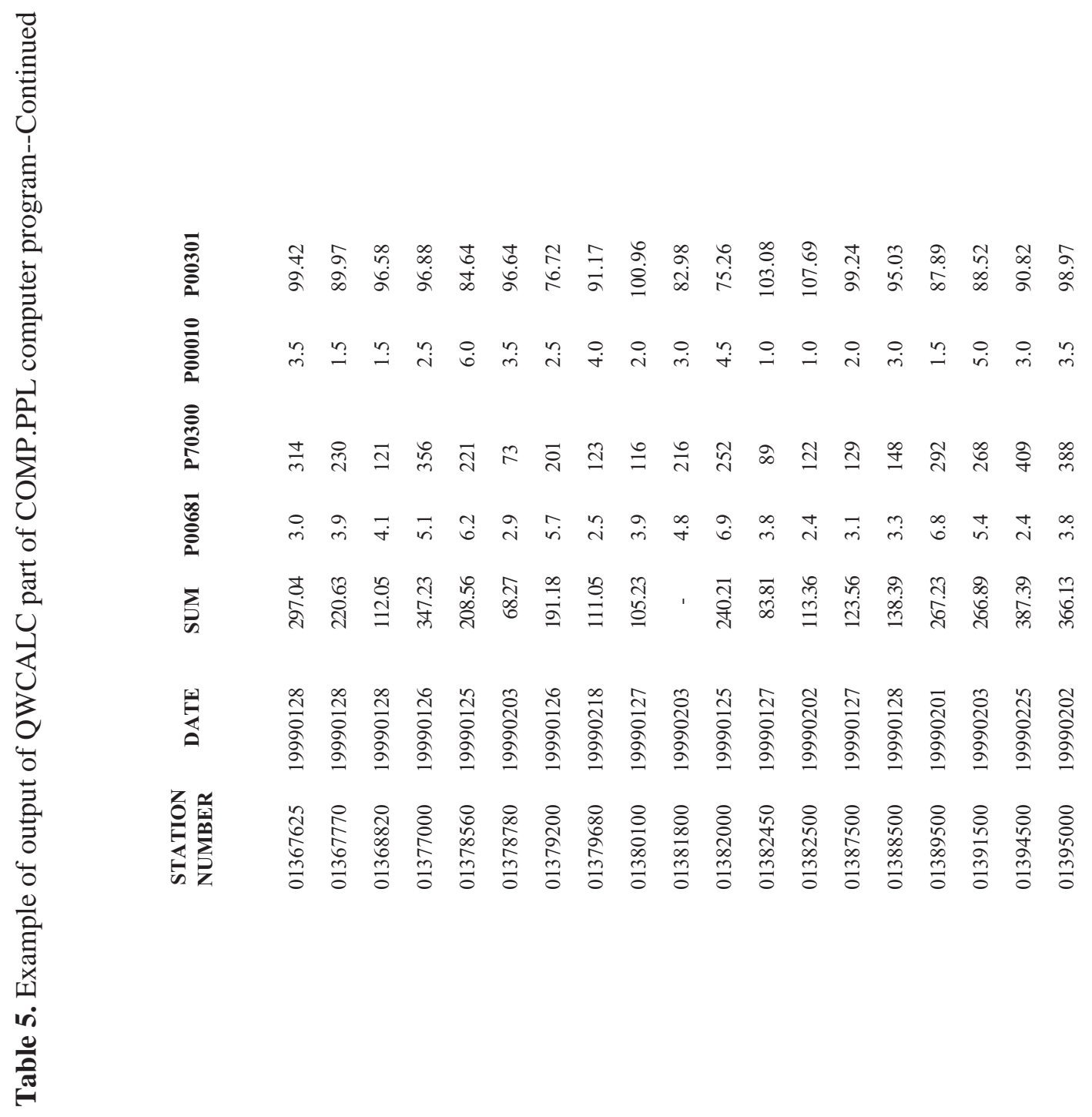


Table 6. Description of parameter codes on the QWCALC printout $\left[\mu \mathrm{S} / \mathrm{cm}\right.$, microsiemens per centimeter; ${ }^{\circ} \mathrm{C}$, degrees Celsius; meq/L, milliequivalents per liter; $\mathrm{mg} / \mathrm{L}$, milligrams per liter]

\section{Column \\ heading}

\section{Value presented}

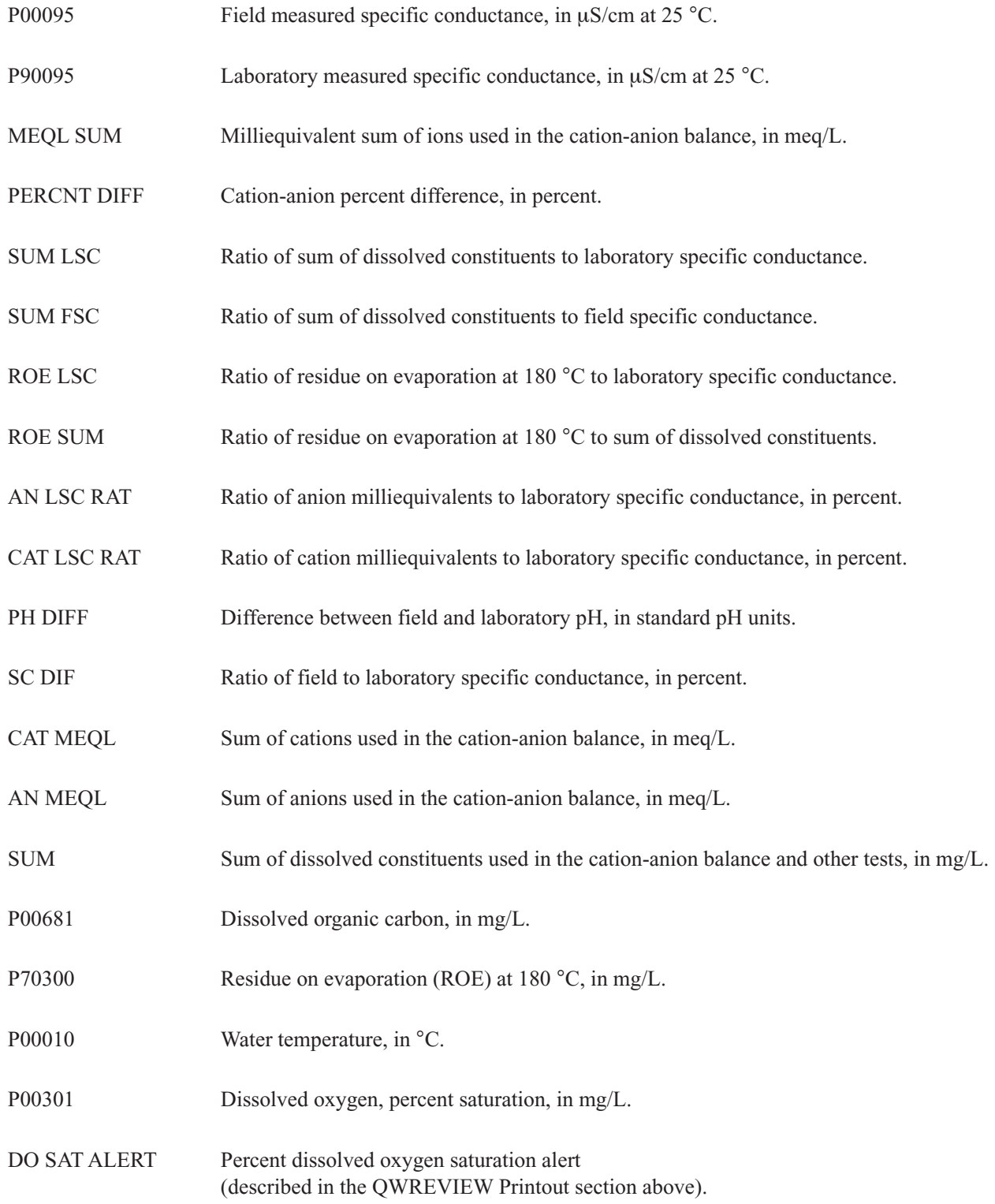




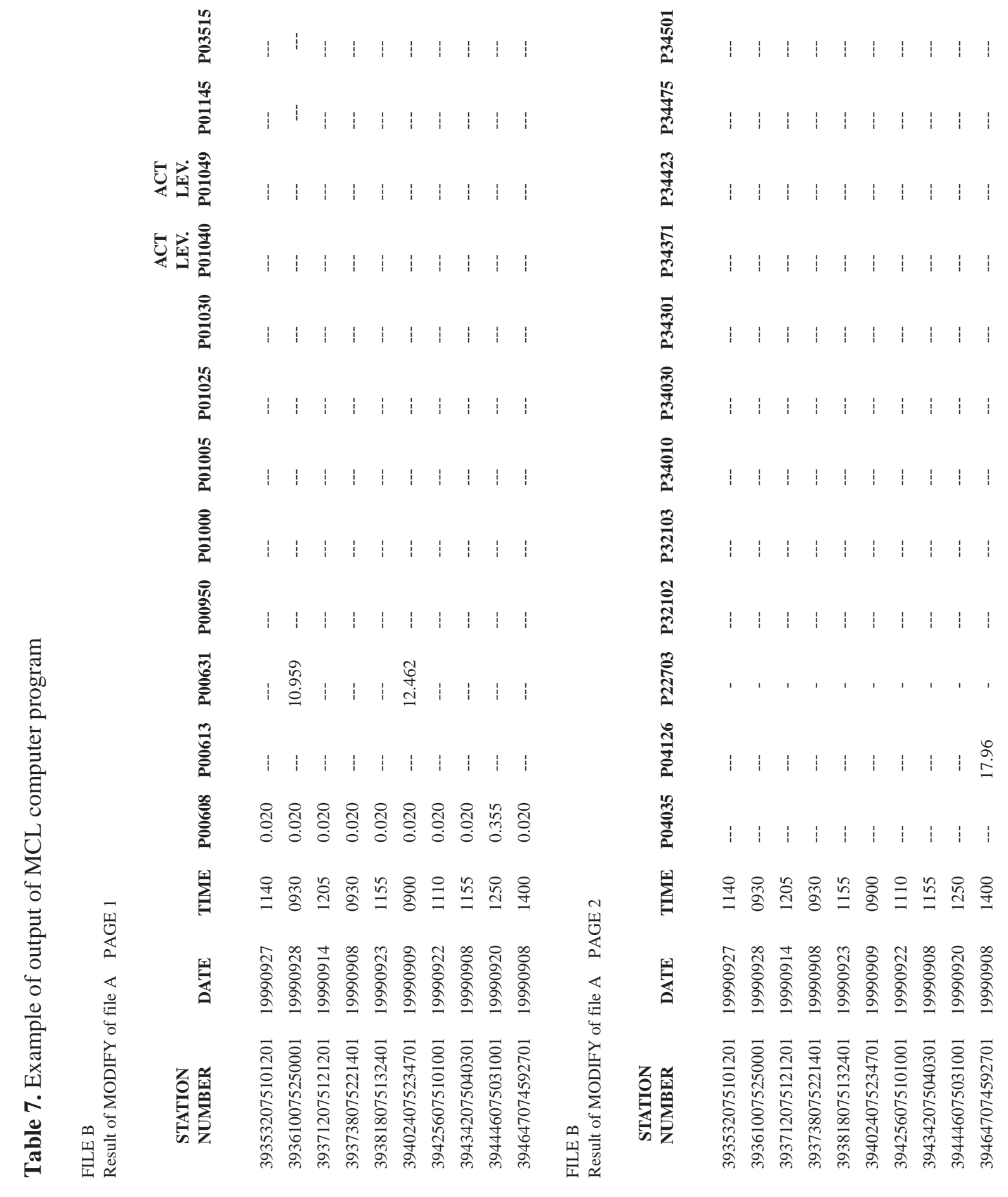




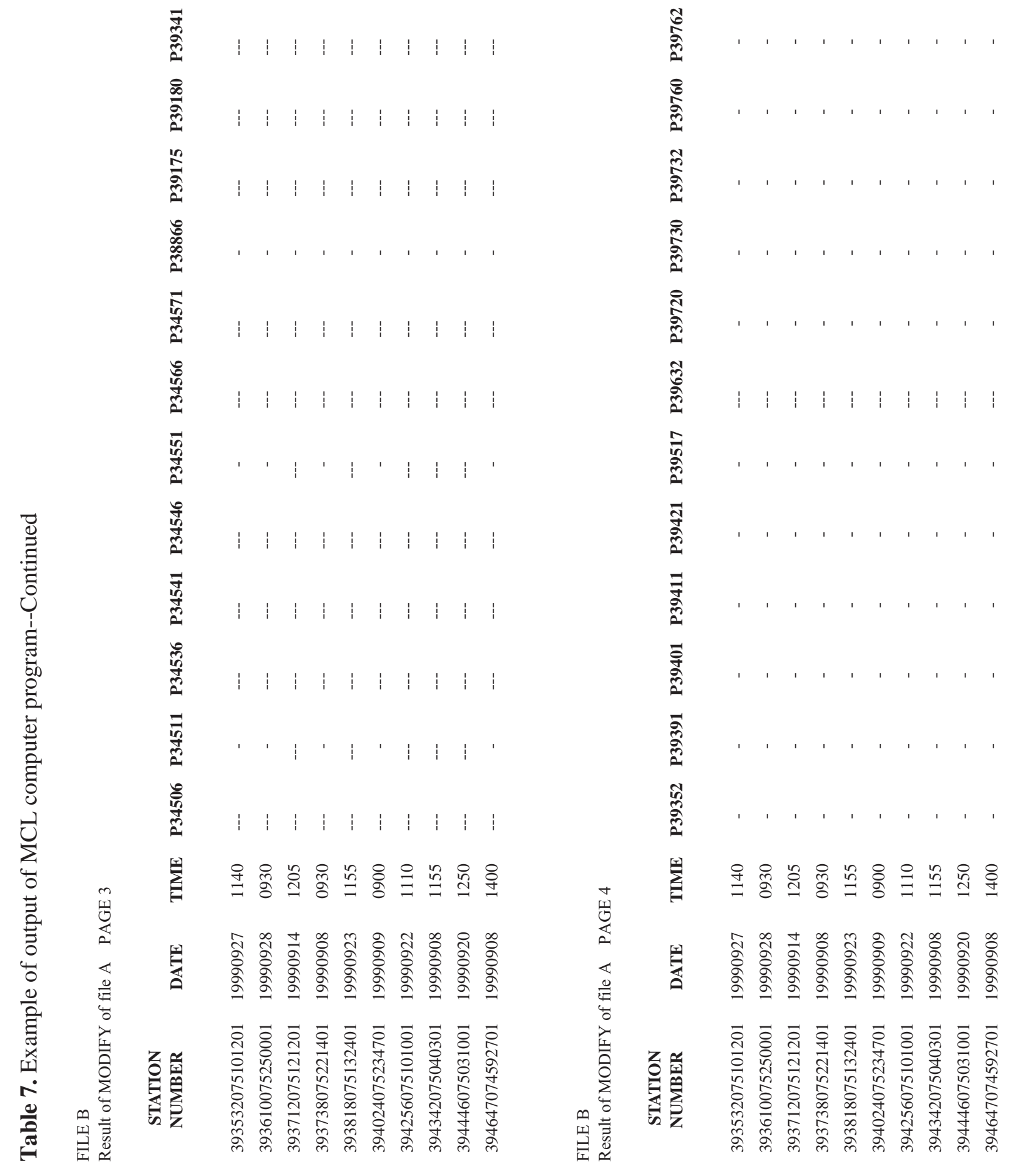




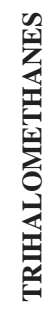

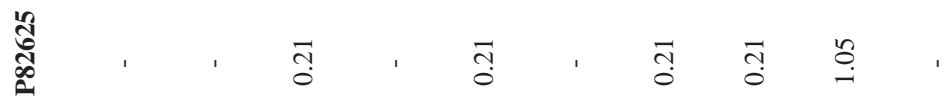

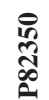

in

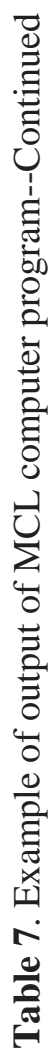

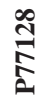

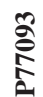

商

商

突

产

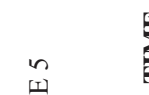

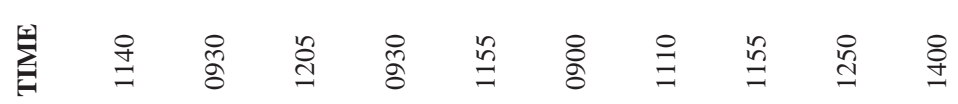

黄啠

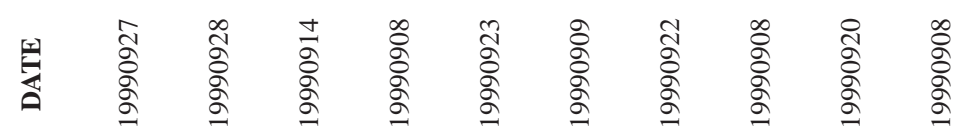

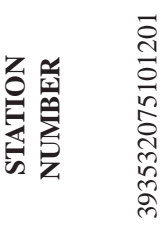

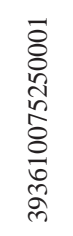

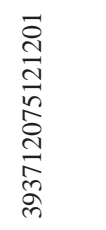

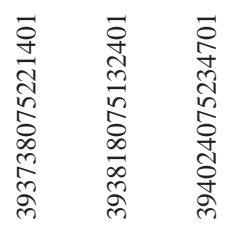

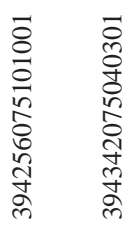

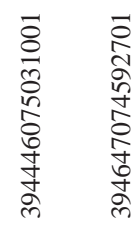

$$
\text { E-7 }
$$

10/8/2002 


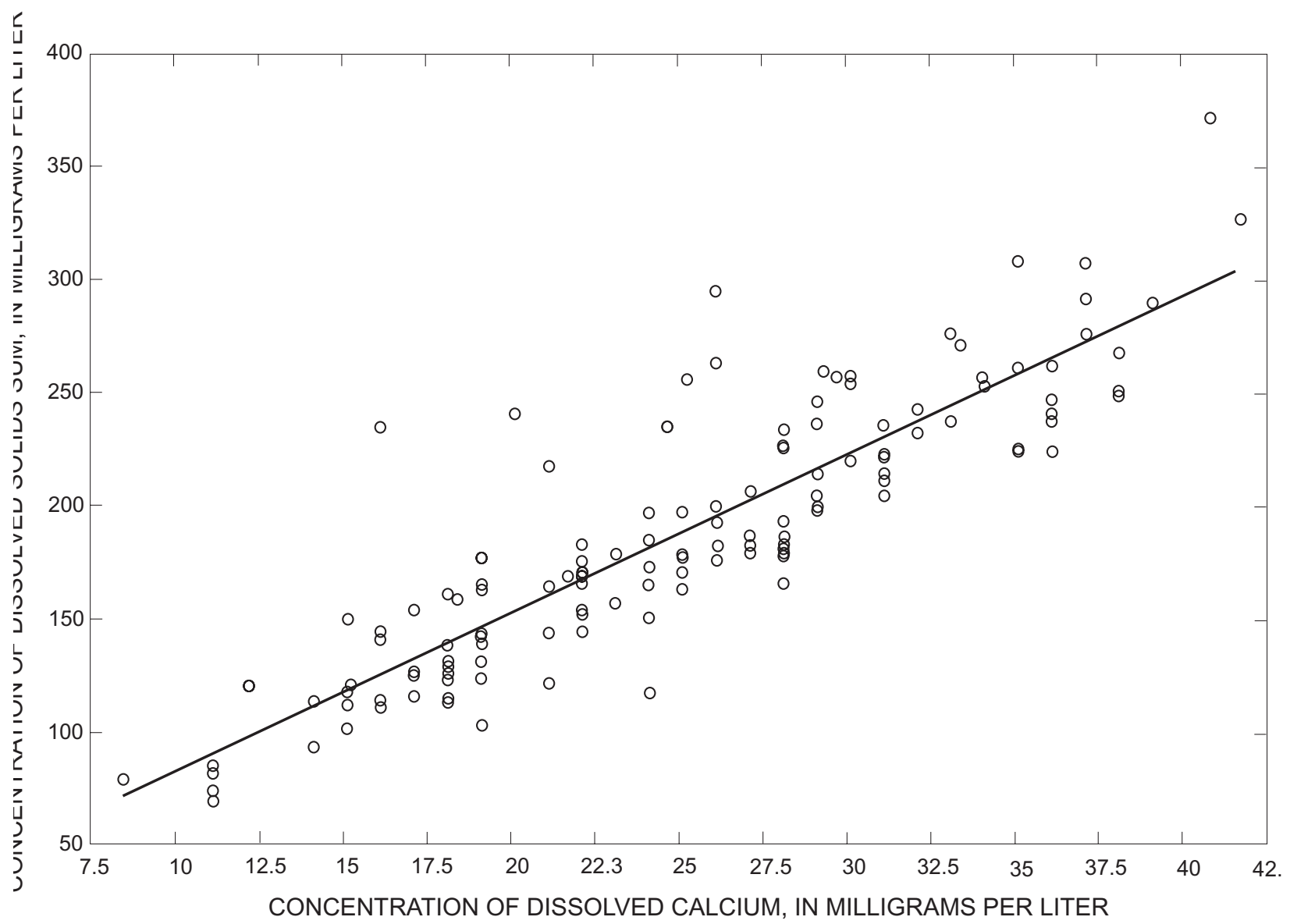

Figure 4. Regression plot of dissolved solids sum in relation to dissolved calcium for the Ramapo River near Mahwah, N.J. 
many radionuclides, such as uranium isotopes, radium-226 ( $\mathrm{Ra}-226)$, and radium-224 ( $\mathrm{Ra}-224)$. This constituent is used as a screening tool. The USEPA MCL for Ra-226 is $5 \mathrm{pCi} / \mathrm{L}$, whereas the MCL for uranium is $30 \mathrm{pCi} / \mathrm{L}$. The MCL for gross alpha, however, is $15 \mathrm{pCi} / \mathrm{L}$. The proposed MCL for radon-222 is $300 \mathrm{pCi} / \mathrm{L}$. Ra-226 is rarely more than one-half of gross alpha, but uranium often contributes almost all the gross alpha. Ra-226 generally is present in water when reducing or acid conditions are present; the DO or ANC (or alkalinity) will be low. The amount of sorption of Ra-226 to solid surfaces is smaller in reducing and acidic environments than in more oxygenated neutral waters, allowing Ra-226 to be in solution. A DO of $5 \mathrm{mg} / \mathrm{L}$ or greater is fairly high for ground water, but uranium tends to be soluble in water with as little as $1 \mathrm{mg} / \mathrm{L}$ to $2 \mathrm{mg} / \mathrm{L}$ of dissolved oxygen. If DO and ANC (or alkalinity) are high, it is nearly certain that the gross alpha is mostly or all uranium. To summarize, if gross alpha is more than $10 \mathrm{pCi} / \mathrm{L}$, then $\mathrm{Ra}-226$ probably is more than the MCL of $5 \mathrm{pCi} / \mathrm{L}$. This concept is based on the 2 to 1 ratio of gross alpha to Ra-226 observed in southern New Jersey by Kozinski and others (1995). To verify, consider asking NWQL to do a Ra-226 analysis or an isotopic uranium analysis. NWQL determines which isotopes of uranium are present. To calculate the Ra-226, subtract the uranium isotopes from gross alpha to get the maximum possible $\mathrm{Ra}-226$. If this difference is greater than 5, get the Ra-226 analysis done anyway.

Beta is another type of radioactivity emitted by many radionuclides. It is emitted by radium228 (Ra-228) and many rare radionuclides. The concentration of Ra-228 should not exceed the drinking-water MCL of $5 \mathrm{pCi} / \mathrm{L}$. In New Jersey, except in the Coastal Plain physiographic province, Ra-228 is generally a small part of gross beta (Welch and others, 1995, p. 491). In the Coastal Plain, however, Ra-228 often exceeds $5 \mathrm{pCi} / \mathrm{L}$ when beta exceeds $10 \mathrm{pCi} / \mathrm{L}$. When gross beta exceeds $10 \mathrm{pCi} / \mathrm{L}$, ask NWQL to analyze for Ra-228.
High concentrations of manganese (greater than $50 \mathrm{mg} / \mathrm{L}$ ) and low concentrations of DO (less than $1.5 \mathrm{mg} / \mathrm{L}$ ) indicate a reducing environment, which is often found in shales, clays, or confined aquifers. This is the kind of environment where Ra-226 and Ra-228 is likely to be present in ground water; uranium is not likely to be present because it precipitates as uranium oxides in these conditions. High concentrations of radium also can be found in acidic conditions. 


\section{QWCALC PRINTOUT}

The COMP.PPL program uses many variables from water-quality data stored in the NWIS water-quality database (U.S. Geological Survey, 2001) and creates others in the course of producing the QWREVIEW printout. Although QWREVIEW is designed to bring attention only to data that may be questionable, other waterquality data are available, both measured and calculated, that the reviewer might find useful. The QWCALC printout (table 5) presents these so that the reviewer does not have to calculate or find them. The QWCALC printout is used mainly as a reference. The headings on the printout as of August 1999 are described briefly in table 6 .

MEQL SUM and SUM/LSC on the QWCALC printout can be used to show the values to expect for a particular geographic or physiographic region. These ratios show, for example, that water in the Pine Barrens is different from other waters in New Jersey.

A good rule of thumb for AN/LSC and CAT/LSC (anions and cations, respectively, divided by laboratory $\mathrm{SC}$ ) is that these ratios should always be in the range of 0.92 to 1.24 . This rule is useful in diagnosing problems with an ionbalance percent difference that is too high; a value outside the range indicates whether the laboratory should reanalyze for a cation or anion.

\section{PROGRAM}

The results of analyses of ground-water samples collected for the USGS/NJDEP AmbientGround-Water-Quality Network program are evaluated with the MCL program in addition to the COMP.PPL program. The QWREVIEW part of the COMP.PPL program will detect internal problems with an analysis. The QWOUTLIERS part of the COMP.PPL program will rarely be effective, however, for ground-water samples because nearly all wells that are sampled have no previous sampling history. The MCL program alerts the reviewer to any analyzed constituents that are greater than NJDEP drinking-water standards. An example of the output of the program is shown in table 7.

\section{REGRESSION ANALYSIS}

The graphs created for regression analysis can assist in determining whether an outlier is reasonable. The graphs also are useful in determining, for instance, whether a field $\mathrm{SC}$ value is more accurate than the laboratory SC value when the values appear to be significantly different. A regression plot of field SC as a function of dissolved solids sum is a good tool for use in determining whether the field SC is reasonable. A regression plot of dissolved solids sum as a function of dissolved calcium is shown in figure 4.

The most useful information for major ions, such as sulfate and calcium, is obtained when they are plotted as a function of SUM or specific conductance (fig. 4). If the major ions are plotted against gage height, the points are too variable or scattered to be useful.

Short computer programs called front-end scripts that are written to work on the SUN computer server provide a convenient method for doing regression analysis. Two scripts allow the reviewer to choose between linear and logarithmic plots and to choose between viewing the plot on the monitor or printing the plot and associated computations. This method quickly plots all requested value pairs in the database for samples collected since October 1, 1975. In addition, if the plot is printed, a file called Regression Results also is printed that gives the reviewer the coefficient and intercept values with which to make regression equations for the 2.5, 50.0, and 97.5 percentile values for the $\mathrm{Y}$-axis constituent for a given value of the $\mathrm{X}$-axis constituent. 


\section{MISCELLANEOUS TIPS TO ASSIST IN DATA REVIEW}

\section{NATIONAL WATER QUALITY LABORATORY TECHNICAL MEMORANDA}

Over the years, the NWQL has issued memoranda relating to such issues as laboratory procedures and changes in methods and reporting levels. Collectively, these are a valuable resource that can be accessed from the NWQL computer home page. To access the site from the New Jersey District internal home page, find "National Water Quality Laboratory" and click on "Internal Page". When the NWQL homepage appears, click on "Technical Information", then click on "Technical Memoranda." All the technical memoranda issued since 1992 are displayed there. To access the website from other districts, use

http://nwql.usgs.gov/Public/nwql_memo.html

\section{RERUNS AND VERIFICATIONS FROM THE NATIONAL WATER QUALITY LABORATORY}

Reruns of analyses (also called reanalyses) can be done by the NWQL while the samples are still at the laboratory. The NWQL keeps unchilled (non-time dependent) bottles of samples for 6 months, then discards the bottles. Nutrient and DOC samples (chilled and, therefore, timedependent), in general, are discarded after 30 days. VOC samples, in general, are discarded after 14 days.

Verifications are requested instead of reruns when the NWQL no longer has the sample of interest. In addition, verifications are requested instead of reruns when the sample is destroyed or used up in the process of analysis. NWQL Policy Memorandum 99.03 (dated July 1,1999) states that NWQL will charge for all verifications when the original analysis was performed more than 18 months previously. The fee is based on the amount of time needed to locate the laboratory data; the time may be significant for data more than 4 years old because the data have been archived.

Requests for reruns and verifications of constituents analyzed for at NWQL were previously made by email. As of October 1, 1998, district personnel are required to use the NWQL web interface implemented through the NWQL homepage for reruns of constituents requested from DENQC, which is

http://wwwnwql.cr.gov/USGS/ district_rerun_request.html

This method may be used for requesting reruns or verifications of inorganic constituents or carbons but not for organic constituents. For reruns of other constituents, organics for example, send requests by email to DENORG (for organics) or to the appropriate email address.

From the NWQL homepage, click on "Services," then click on "District Rerun Request Form." This form allows the user to request reruns or verifications on as many as four constituents at a time for a particular sample. To move between fields on the form, use the tab key or click on the desired field. All blanks must be filled in under the section "Mandatory Information"; if there is no remark code for the constituent value, however, the space for this will remain blank. Most of the information needed to fill in the form is found on the NWIS printout of laboratory and field data (WATLIST table). When the form is complete and ready to be transmitted, click on "Submit Request." If transmission was successful, a screen will be seen with the heading "THIS REQUEST HAS BEEN SUBMITTED" and details of the transaction. If transmission was not successful, an error message will be seen telling the user to return to the form, for example, and fill in all the required fields. After successful transmission of the request, go to the "File" menu and click on the "Print" option to get a paper copy of the transaction, or click on the "Save As" option to copy it to a computer file. 
Do not request reruns of laboratory $\mathrm{pH}$. As of January 1994, NWQL no longer does reruns of $\mathrm{pH}$.

When reruns are requested because of an unacceptable major ion balance, consider asking the laboratory to rerun both the major cations and major anions. If laboratory ANC (acid-neutralizing capacity, previously called alkalinity) is requested as one of the ions to be rerun, keep in mind that NWQL charges extra for reruns of ANC. Major ions are listed below.

\begin{tabular}{ll}
\hline Cations & Anions \\
\hline Calcium & Chloride \\
Magnesium & Sulfate \\
Sodium & Fluoride \\
Potassium & Acid-neutralizing capacity \\
\hline
\end{tabular}

Dissolved NO2 and NO3 are sometimes shown in the ion-balance percent difference section of the laboratory analysis and appear to be major ions, but the laboratory can't rerun analyses for these after 30 days because the samples have been discarded.

Before requesting reruns, always check "REMARKS FROM LAB" on the NWIS printout of laboratory and field data for remarks such as:

"Anions RR and dup'ed." This means the analyses for anions were rerun and the values were duplicated. Anions in this case include $\mathrm{Cl}, \mathrm{SO} 4$, and fluoride but do not include laboratory ANC.

"Alk RR and dup'ed." This means that the analysis for laboratory ANC was rerun by the laboratory, and the value was duplicated.

"KJD RR DUP." This means that the analyses for dissolved and total KJD (Kjeldahl nitrogen) were rerun, and the results are in agreement with the original values.

\section{NATIONAL WATER QUALITY LABORATORY INTERNAL QUALITY ASSURANCE}

The NWQL performs quality-assurance checks on analyses before the data ever leave the laboratory. The review process used is explained in NWQL Technical Memorandum 93-02 dated October 5, 1992. This memorandum, as well as the other technical memoranda, can be accessed from the NWQL homepage.

\section{STREAMBED SAMPLES}

The COMP.PPL program is not helpful in assisting the review of analyses of streambed material (bottom sediments). Samples of streambed material are collected for the USGS/ NJDEP Ambient-Stream-Monitoring Network program only in the fall and only at some sites, so few data on streambed sediment samples are stored in the database. A good way to assess the results of streambed-material analyses is to make a retrieval of all such results in the database for the sites being reviewed. Compare current values with historical values. If a value seems unusually high or low, compare it with the value of the same constituent from the water column analysis, if that is available. Reruns of trace elements in streambed material can be done by NWQL. Reruns of organic compounds in bed material cannot be done because the sample is used up during the process of analysis; however, the laboratory can, upon request, save solvent extracts of the streambed material.

When a water-column analysis and a streambed-material analysis are done for the same site, do not wait until the results of the streambedmaterial analysis are received to review the results of the water-column analysis. The reason for this is the streambed-material analysis comes back about 2 months later than the water-column analysis; the review of the water-column analysis should not wait that long. This means that the packet for a sample that has a streambed-material analysis must be reviewed twice. 


\section{LOW-IONIC-STRENGTH LOW-pH WATER}

Stream water in nutrient-poor terrains can have low specific conductances and low $\mathrm{pH}$. The New Jersey Pine Barrens is an example of such a terrain. Specific conductances in streams in the New Jersey Pine Barrens are typically less than $100 \mu \mathrm{S} / \mathrm{cm}$ and can be as low as $20 \mu \mathrm{S} / \mathrm{cm}$. Values of $\mathrm{pH}$ in these New Jersey streams also are low and range generally from 4 to 6 but can be as low as 3 or as high as 7. Outliers in data for these sites are allowed more leeway in data review because, at such low concentrations, analytical imprecision results in larger percentage errors.

ROE values at these sites can be high-end outliers or be flagged by the ROE/SUM test because of organic compounds in the water. The ratio ROE to SUM should be greater than 2.0 at these sites before a rerun of ROE is considered.

The magnesium to calcium ratio can be quite high in these waters, and as a result, the $\mathrm{CA} / \mathrm{MG}$ test can fail. The ratio shown in the COMP.PPL QWREVIEW printout as CA/MG is the molar ratio of $\mathrm{Mg}$ to $\mathrm{Ca}$, not of $\mathrm{Ca}$ to $\mathrm{Mg}$. Ratios as high as 1.8 or even higher are allowed for this test. The ion concentrations themselves are quite low, and this test is not reliable at these low concentrations.

$\mathrm{K}$ at these sites can be extremely low, even less than the MRL in water year 2002 of $0.11 \mathrm{mg} / \mathrm{L}$. Most of the available $\mathrm{K}$ in the nutrientdeficient environment is taken up by plants and never shows up in the water.

$\mathrm{Fe}$ and $\mathrm{Cl}$ concentrations can be slightly elevated above historical median values during low flows. A small increase in these can easily result in an outlier or a new maximum for a site. Fe can be high after a rain because rain flushes water with low concentrations of DO and high concentrations of $\mathrm{Fe}$ out of the peat bogs and swamps and can suspend the Fe contained in streambed sediments.
$\mathrm{SiO} 2$ is low at these sites, less than $10 \mathrm{mg} / \mathrm{L}$. New low values a little below previous all-time lows occasionally occur.

Laboratory ANC and field alkalinity at these sites often seem to be a problem when field and laboratory values are compared. Concentrations are very low in New Jersey streams, and the precision is + or $-1 \mathrm{mg} / \mathrm{L}$. Although the two values can differ greatly by percentage, they are often acceptable. A field alkalinity of 2 is twice as large as a laboratory ANC of 1, but it is within the precision of the measurement.

High concentrations of COD in water from these sites can be attributed to high concentrations of DOC. DOC is present in shallow ground water that seeps from bogs and swamps, especially from peat bogs. COD and DOC can be higher than historical median values during, and for a couple of days after, a rain. A value of 15 or $20 \mathrm{mg} / \mathrm{L}$ for COD is not too high during and after a heavy rain.

Ion balance percent difference for these sites could be quite different on the COMP.PPL printout from that shown on the WATLIST table. This is because $\mathrm{H}+$ ion is never included in the percent difference seen on the WATLIST table, whereas it is included in the percent difference on the COMP.PPL printouts. This becomes a consideration at low $\mathrm{pH}$ conditions because a lot of the $\mathrm{H}+$ ion is a large part of the ion balance. Thus, for some analyses, the percent difference on the WATLIST table is a negative value, but it is not flagged on the COMP.PPL program output. In other words, even if the percent difference shown on the WATLIST table is a high negative value, the reviewer should not be concerned as long as the COMP.PPL program does not flag it as being a problem. 


\section{SUMMARY}

Quality-assurance review is one of the many steps involved in the collection, review, and publication of water-quality data in the New Jersey District of the U.S. Geological Survey (USGS). COMP.PPL is a statistical analysis computer program developed and used by the District to assure the accuracy and precision of water-quality-analysis results received from analyzing laboratories. The use of this program ensures the integrity of water-quality data in USGS databases and published reports. The computer program runs tests to determine whether the data for a particular sample are internally consistent, whether the values are reasonable in a historical context for the sampling site, and whether they exceed drinking-water regulations. This report is a reference manual that describes the computer program and provides information that may help a user interpret the results of the program.

The program output consists of three files-QWREVIEW, QWOUTLIERS, and QWCALC. The QWREVIEW output shows results of tests of chemical logic and alerts the data reviewer to values that exceed drinking-water regulations. The QWOUTLIERS output identifies values that fall outside the range of values occurring 95 percent of the time at a site. The QWCALC output shows values and calculations for reference purposes.

The reviewer uses technical judgement when looking at values identified by the program as questionable; the values may or may not be in error. This report presents information intended to help the reviewer decide whether to accept a questionable value or investigate further. Regression analysis is a tool that helps the reviewer make this decision. Use of an auxiliary computer program called MCL for evaluating the results of analyses of ground-water samples is described; the output alerts the reviewer to values that are greater than maximum contaminant levels.

The analyzing laboratories can be requested to reanalyze or verify questionable values. If a value is still questionable after reanalysis or verification, consideration must be given to deleting the value or marking the value in the National Water Information System (NWIS) database as having been reviewed and rejected.

\section{SELECTED REFERENCES}

Bhattacharyya, G.K., and Johnson, R.A., 1977, Statistical concepts and methods: New York, John Wiley \& Sons, 639 p.

Berner, E.K., and Berner, R.A., 1987, The global water cycle: Englewood Cliffs, N.J., Prentice-Hall, 397 p.

Buxton, D.E., Hunchak-Kariouk, Kathryn, and Hickman, R.E., 1998, Relations of surfacewater quality to streamflow in the Hackensack, Passaic, Elizabeth, and Rahway River Basins, New Jersey, water years 1976-93: U.S. Geological Survey Water-Resources Investigations Report 98-4049, $102 \mathrm{p}$.

Buxton, D.E., Hunchak-Kariouk, Kathryn, and Hickman, R.E., 1999a, Relations of surfacewater quality to streamflow in the Raritan River Basin, New Jersey, water years 197693: U.S. Geological Survey Water-

Resources Investigations Report 99-4045, $100 \mathrm{p}$.

Buxton, D.E., Hunchak-Kariouk, Kathryn, and Hickman, R.E., 1999b, Relations of surfacewater quality to streamflow in the Wallkill and Upper Delaware River Basins, New Jersey and vicinity, water years 1976-93: U.S. Geological Survey Water-Resources Investigations Report 99-4016, 98 p.

Cabelli, V.J., 1977, Indicators of recreational water quality, in Hoadley, A.W., and Dutka, B.J., eds., Bacterial indicators/health hazards associated with water, 1977: American Society for Testing and Materials, ASTM STP 635, p. 222-238. 


\section{SELECTED REFERENCES-- Continued}

Clesceri, L.S., Greenberg, A.E., and Eaton, A.D., eds., 1998, Standard methods for the examination of water and wastewater (20th ed.): Baltimore, Md., United Book Press, miscellaneous pagination.

Clesceri, L.S., Greenberg, A.E., and Trussell, R.R., eds., 1990, Selected physical and chemical standard methods for students: Baltimore, Md., Port City Press, 607 p.

Cornell University, 2001, Cornell guide for integrated field crop management: Cornell University, accessed June 17, 2002, at URL http://www.css.cornell.edu/extension/ CornellGuidepdfFiles/Field_Crops.pp2431.pdf

DeLuca, M.J., Oden, J.H., Romanok, K.M., and Riskin, M.L., 1999, Water-resources data for New Jersey - water year 1998, Volume 3. Water-quality data: U.S. Geological Survey Water-Data Report NJ-98-3, 450 p.

Drever, J.I., 1988, The geochemistry of natural waters ( $2 \mathrm{~d}$ ed.): Englewood Cliffs, N.J., Prentice-Hall, 437 p.

Dufour, A.P., and Cabelli, V.J., 1984, Health effects criteria for fresh recreational waters: Cincinnati, Ohio, U.S. Environmental Protection Agency, EPA 600/1-84-004, 33p.

Fishman, M.J., and Friedman, L.C., eds., 1989, Methods for determination of inorganic substances in water and fluvial sediments: U.S. Geological Survey Techniques of Water-Resources Investigations, book 5 , chap. A1, 545 p.

Friedman, L.C., and Erdmann, D.E., 1982, Quality assurance practices for the chemical and biological analyses of water and fluvial sediments: U.S. Geological Survey Techniques of Water-Resources Investigations, book 5, chap. A6, $181 \mathrm{p}$.
Hem, J.D., 1992, Study and interpretation of the chemical characteristics of natural water $(3 \mathrm{~d}$ ed.): U.S. Geological Survey Water-Supply Paper 2254, $263 \mathrm{p}$.

Hunchak-Kariouk, Kathryn, 1999, Relation of water quality to land use in the drainage basins of four tributaries to the Toms River, New Jersey, 1994-95: U.S. Geological Survey Water-Resources Investigations Report 99-4001, 120 p.

Hunchak-Kariouk, Kathryn, Buxton, D.E., and Hickman, R.E., 1999, Relations of surfacewater quality to streamflow in the Atlantic Coastal, Lower Delaware River, and Delaware Bay Basins, New Jersey, water years 1976-93: U.S. Geological Survey Water-Resources Investigations Report 98-4244, 146 p.

Kozinski, Jane, Szabo, Zoltan, Zapecza, O.S., and Barringer, T.H., 1995, Natural radioactivity in, and inorganic chemistry of, ground water in the Kirkwood-Cohansey aquifer system, southern New Jersey, 1983-89: U.S. Geological Survey Water-Resources Investigations Report 92-4144, 130 p.

Leenhouts, J.M., Bassett, R.L., and Maddock, T., III, 1998, Utilization of intrinsic boron isotopes as co-migrating tracers for identifying potential nitrate contamination sources: Ground Water, v.36, no. 2, p. 240250 .

Manahan, S.E., 1993, Fundamentals of environmental chemistry: Chelsea, Mich., Lewis Publishers, 844 p.

Mitsch, W.J., and Gosselink, J.G., 1993, Wetlands ( $2 \mathrm{~d}$ ed.): New York, John Wiley, 722 p.

New Jersey Department of Environmental Protection, April 1998, Surface water quality standards: Trenton, N.J., New Jersey Department of Environmental Protection, $122 \mathrm{p}$. 


\section{SELECTED REFERENCES--Continued}

P-STAT, Inc., 1997, P-STAT user's manual: Hopewell, N.J., P-STAT, Inc., 3 v., unpaginated.

Ruffner, J.A., and Bair, F.E., eds., 1977, The weather almanac (2d ed.): Detroit, MI, Gale Research Co., Book Tower, $35 \mathrm{p}$.

Sawyer, C.N., and McCarty, P.L., 1978, Chemistry for environmental engineering: New York, McGrawHill, $532 \mathrm{p}$.

Shelton, T.B., 1996, Interpreting drinking water quality analysis - What do the numbers mean? (5th ed.): New Brunswick, N.J., Rutgers Cooperative Extension, 63 p.

Spiegel, M.R., 1961, Schaum's outline of theory and problems of statistics: New York, McGraw-Hill, 359 p.

U.S. Environmental Protection Agency, 1986, Ambient water quality criteria for bacteria--1986:

Washington, D.C., U.S. Environmental Protection Agency, Office of Water Regulations and Standards Division, EPA 440/5-84-002, p.15.

Dec. 7, 2000, National primary drinking water regulations, Radionuclides, Final Rule: U.S. Federal Register, v. 65, no. 236, p. 76,707-76,753.

U.S. Geological Survey, 1999, Validation of U.S. Environmental Protection Agency (USEPA) method 365.1 to replace U.S. Geological Survey (USGS) TWRI methods I-2607-90 and I-4607-90 for determination of phosphorus in the concentration range from 0.004 to $0.200 \mathrm{mg}-\mathrm{P} / \mathrm{L}$ : National Water Quality Laboratory Technical Memorandum No. 99.05, accessed June 18, 2002, at URL http://nwql.usgs.gov/Public/nwql_memo.html 
2000, Changes in minimum reporting levels for suspended solids analyses at the NWQL (lab codes 49 and 169): National Water Quality Laboratory Technical Memorandum 00.03, accessed June 18, 2002, at URL http://nwql.usgs.gov/Public/ nwql_memo.html

2001, User's manual for the National Water Information System of the U.S. Geological Survey, version 4_1: Unpublished report available at U.S. Geological Survey, West Trenton, N.J.

Ward, A.D., and Elliot, W.J., 1995, Environmental Hydrology: Boca Raton, Fla., Lewis Publishers, 462 p.

Welch, A.H., Szabo, Zoltan, Parkhurst, D.L., Van Metre, P.C., and Mullin, A.H., 1995, Grossbeta activity in ground water: natural sources and artifacts of sampling and laboratory analysis: Applied Geochemistry, v. 10, p. 491-503. 
